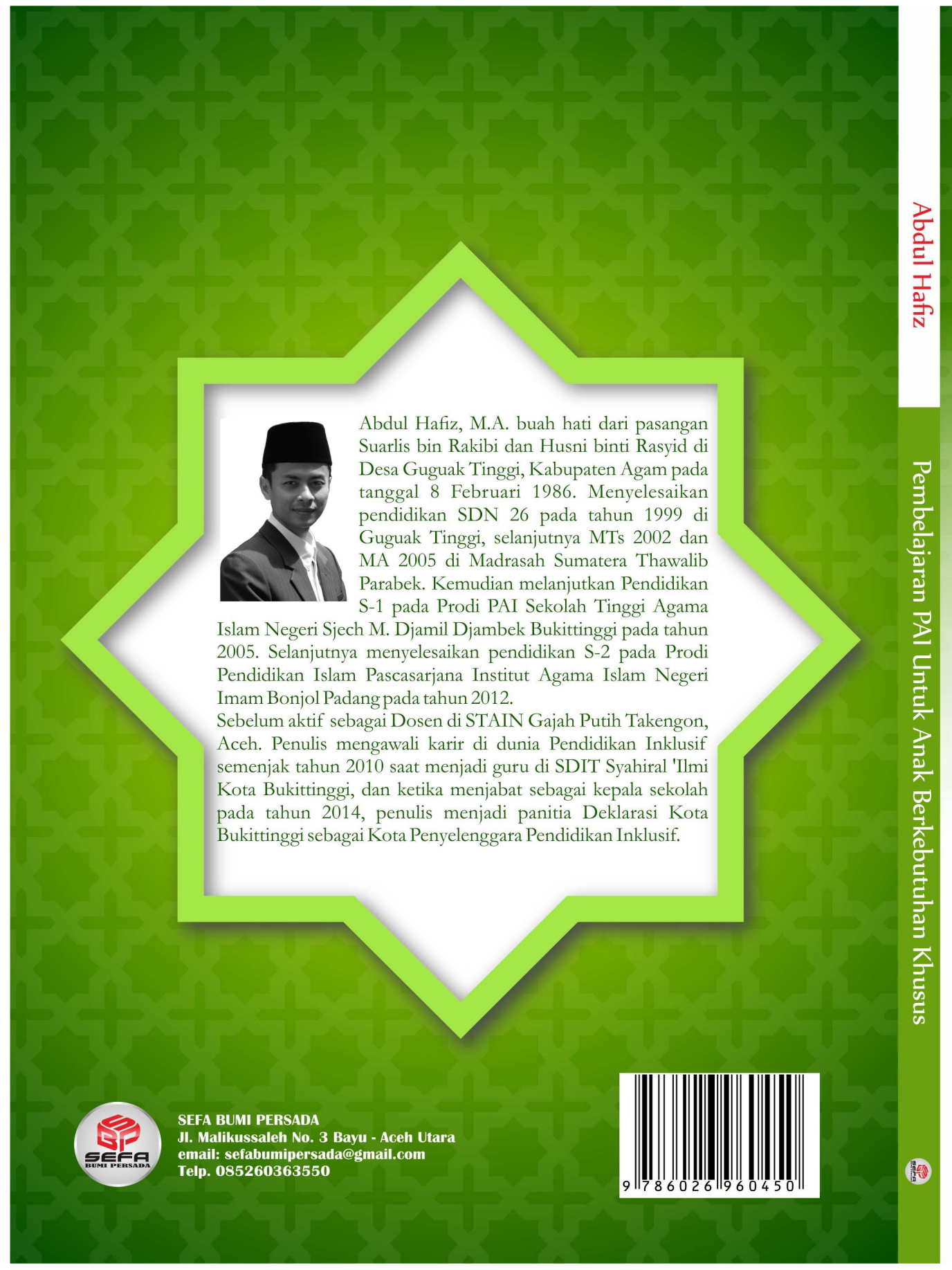

\title{
Pembelajaran PAI Untuk Anak Berkebutuhan Khusus
}

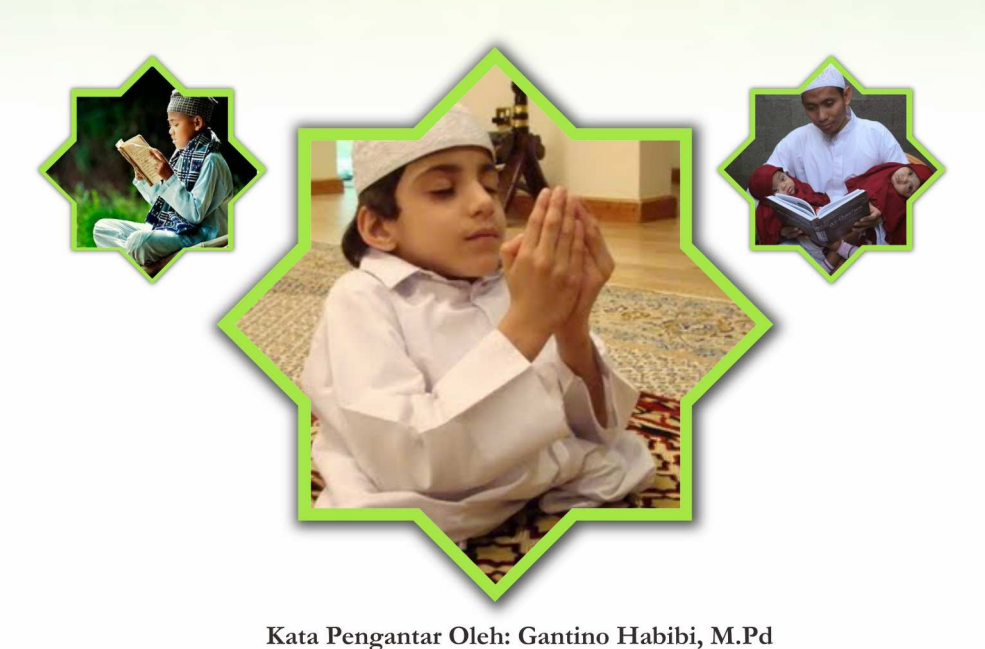




\section{PEMBELAJARAN PAI UNTUK ANAK BERKEBUTUHAN KHUSUS}

Abdul Hafiz, MA

PENERBIT

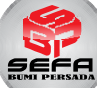

2017 
PEMBELAJARAN PAI UNTUK ANAK BERKEBUTUHAN KHUSUS

Oleh : Abdul Hafiz, MA

Hak Cipta @ 2017 pada Penulis

Cover Design \& layout $\quad$ : Muhammad Rizki, S. Kom. I $I^{(S E F A)}$

Pracetak dan Produksi $\quad$ : CV. Sefa Bumi Persada

Hak Cipta dilindungi undang-undang.

Hak Cipta dilindungi undang-undang.

Dilarang memperbanyak atau memindahkan sebagian atau seluruh isi buku ini dalam bentuk apapun, baik secara elektronis maupun mekanis, termasuk memfotokopi, merekam atau dengan sistem penyimpanan lainnya, tanpa izin tertulis dari Penulis

Penerbit:

\section{SEFA BUMI PERSADA}

J1. B. Aceh - Medan, Alue Awe - Lhokseumawe

email: sefabumipersada@gmail.com

Telp. 085260363550

Abdul Hafiz

PEMBELAJARAN PAI UNTUK ANAK BERKEBUTUHAN KHUSUS

Cetakan I : Agustus 2017-Lhokseumawe

Cetakan II: Desember 2017 - Lhokseumawe

ISBN: 978-602-6960-45-0

1. Hal. $144: 16,5 \times 24 \mathrm{~cm} \quad$ I. Judul 


\section{KATA PENGANTAR}

\section{- Gantino Habibi, M.Pd -}

Buku ini sangat menarik dan memberi pendalaman terhadap konsep bagaimana pembelajaran yang hakiki dapat dilakukan dengan baik. Terutama bagi guru-guru pendidikan agama Islam. Ketika kita membaca buku ini dari awal hingga akhir sentuhan yang jarang dialami selama ini bagaimana implementasi pendidikan inklusif di kelas. Buku ini membantu kita untuk memahami tahap aksi di kelas bersama siswa berkebutuhan khusus sehingga kendala yang selama ini terjadi berkenaan dengan penerapan pendidikan inklusif dapat diatasi dengan membaca buku ini. Model-model dan contoh yang dipaparkan dalam buku ini dapat menjadi rujukan. Saya yakin buku ini menjadi buku terpenting dalam dunia pendidikan dalam memperhatikan anak-anak berkebutuhan khusus dan membantu para guru serta praktisi pendidikan dalam menganalisa berbagai kelebihan-kelemahan terhadap pendidikan inklusif. Semoga buku yang luar biasa ini menjadi salah satu solusi bagi pendidik khususnya guru pendidikan agama Islam dalam memberi dan melayani kebutuhan pendidikan bagi siswa berkebutuhan khusus dan siswa-siswa lainnya.

\section{Tiga kata untuk buku ini:}

cerdas - inspiratif - aplikatif

\section{Prestasi Gantino Habibi, M.Pd}

Tahun 2017, Juara 1 Kepala SD Berpretsasi Nasional, Tahun 2016, Juara 1 Penulisan Best Practice Nasional, Tahun 2013, Penerima Inclusive Education Award dari Menteri Pendidikan, Tahun 2009, dan Juara 1 Lomba Karya Tulis Ilmiah Nasional 


\section{KATA PENGANTAR PENULIS}

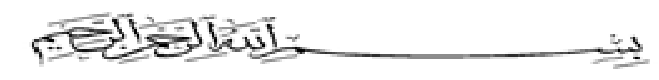

Dengan memanjatkan puji syukur ke hadirat Allah Swt, atas segala limpahan rahmat dan karunia-Nya, shalawat beserta salam kita hadiahkan buat junjungan kita Rasulullah Saw serta keluarga dan sahabat beliau. Ucapan terima kasih Penulis ucapakan kepada Direktorat Pendidikan Tinggi Islam Ditjen Pendidikan Islam Kementrian Agama yang telah mensukseskan keseluruhan penerbitan buku ini.

Secara Khusus, buku ini penulis persembahkan sebagai kado ulang tahun buat istri tercinta Nofil Gusfira, S.H., M.H. Yang siang malam mendidik dua Jundullah yaitu; Ibnu Azamil Quwa, dan Mujahid Haziq Hawari.

Alhamdulillah, buku Pembelajaran Pendidikan Agama Islam untuk Anak Berkebutuhan Khusus ini hadir mensukseskan pembelajaran PAI di sekolah-sekolah penyelenggara pendidikan inklusif (pensif) bagi siswa ABK. Sejak dicetuskannnya pensif pada tahun 2003 silam, hingga saat ini beberapa daerah masih belum menyelenggarakan pensif dengan berbagai alasan. Begitu pula sekolah-sekolah yang telah ditunjuk menyelenggarakan pensif masih terjadinya kegalauan para guru PAI dalam melaksanakan pembelajaran sangat terlihat sekali dengan berbagai penafsiran yang muncul tentang pelaksanaan pengajaran yang dilakukan sama dengan pengajaran anak normal, begitu juga dengan penilaiannya. Sedangkan kemampuan siswa ABK ini sangat bervariasi, sehingga dibutuhkan berbagai bentuk pengajaran yang disesuaikan dengan kemampuan mereka. Oleh sebab itu penulis mengira sangat perlu kiranya untuk ikut serta mensosialisasikan pensif ini kepada lembaga-lembaga pendidikan maupun masyarakat akademis dan awam. Agar lebih efektif penulis menyusun sebuah buku yang dapat menjadi pedoman bagi guru-guru PAI, mahasiswa PAI, orang tua, serta pengawas PAI dan pemerhati Pendidikan Agama Islam.

Akibat dari kurangnya pengetahuan guru-guru PAI tentang pensif ini menjadikan persolan baru dalam pengajaran PAI di sekolah-sekolah penyelenggara pensif. Persoalan yang dihadapi oleh guru-guru adalah bagaimana mengajar ABK agar lebih efektif, bagaimana mengatasi permasalahan, bentuk penilaian, format rapor yang masih diperdebatkan.

Dalam buku ini nantinya akan menjawab beberapa pertanyaan yang selama ini menjadi bahan pemikiran guru-guru PAI yang ada di sekolah Inklusif. Oleh sebab itu penulis memaparkan beberapa teori yang disertai dengan praktek agar menjadi acuan yang dapat diaplikasikan di kelas 
nantinya, sehingga pembelajaran PAI untuk ABK tidak menjadi permasalahan lagi di sekolah-sekolah penyelenggara pendidikan inklusif.

Takengon, 27 Agustus 2017

Abdul Hafiz, M.A. 
KATA PENGANTAR -- i

DAFTAT ISI -- iv

DAFTAR TABEL -- vii

DAFTAR FORMULIR -- viii

DAFTAR GAMBAR -- ix

\section{BAB 1 PENDAHULUAN}
A. Latar Belakang -- 1
B. Tujuan -- 5
C. Ruang Lingkup -- 6
D. Kerangka Pendekatan -- 6
E. Struktur Buku -- 6

BAB 2 PENDIDIKAN INKLUSIF
A. Konsep Dasar Pendidikan Inklusif -- 9
B. Landasan Pendidikan Inklusif -- 11
C. Prinsip-prisip Pendidikan Inklusif - 13
D. Profil Pembelajaran Sekolah Inklusif -- 14
E. Permasalahan Pendidikan Inklusif -- 16

\section{BAB 3 ANAK BERKEBUTUHAN KHUSUS}
A. Konsep Dasar ABK -- 19
B. Klasifikasi ABK -- 20

BAB 4 IDENTIFIKASI DAN ASESMEN ABK
A. Identifikasi ABK -- 29
B. Asesmen ABK -- 37

\section{BAB 5 LAYANAN PENDIDIKAN UNTUK ABK}
A. Intelektual di bawah rata-rata -- 49
B. Gangguan Perilaku -- 51 
C. Autisme -- 55

\section{BAB 6 PEMBELAJARAN PENDIDIKAN AGAMA ISLAM}
A. Konsep Dasar Pembelajaran PAI -- 59
B. Landasan Historis PAI -- 62
C. Ruang Lingkup PAI -- 65
D. Isu-isu Pembelajaran PAI -- 65

\section{BAB 7 DISAIN KURIKULUM PAI UNTUK ABK}
A. Konsep Dasar Kurikulum -- 67
B. Asas-asas Kurikulum -- 69
C. Fungsi Kurikulum -- 78
D. Jenis-jenis Kurikulum -- 79
E. Implementasi Kurikulum PAI untuk ABK -- 84

\section{BAB 8 GURU UNTUK ABK}
A. Konsep Dasar Guru -- 93
B. Tugas Pokok Guru -- 94
C. Kompetensi Guru -- 101

\section{BAB 9 PERENCANAKAN PEMBELAJARAN ABK}
A. Konsep Dasar Perencanakan Pembelajaran -- 105
B. Implementasi Perencanaan dalam sekolah Inklusif -- 108

\section{BAB 10 MEDIA PEMBELAJARAN UNTUK ABK}
A. Konsep Dasar Media untuk ABK -- 113
B. Fungsi Media Pembelajaran untuk ABK -- 114
C. Jenis-jenis Media Pembelajaran untuk ABK --115
D. Kriteria Pemilihan Media Pembelajaran untuk ABK -- 117

\section{BAB 11 EVALUASI PEMBELAJARAN ABK}
A. Konsep Dasar Evaluasi Pembelajaran ABK -- 119
B. Tujuan Evaluasi Pembelajaran - 120
C. Fungsi Evaluasi Pembelajaran -- 120
D. Prinsip Evaluasi Pembelajaran -- 121 
E. Jenis-jenis Evaluasi Pembelajaran -- 121

F. Teknik Evaluasi Pembelajaran -- 122

G. Bentuk Laporan Akademik ABK -- 125

BAB 12 KESIMPULAN -- 127

DAFTAR PUSTAKA

BIODATA PENULIS 


\section{DAFTAR TABEL}

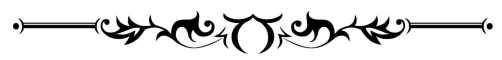

Tabel 4.1 Alat identifikasi anak berkebutuhan khusus -- 31

Tabel 4.2 Matrik Perkembangan Belajar -- 39

Tabel 4.3 Ceklis Pengamatan Membaca -- 40

Tabel 4.4 Formulir Kebiasaan Menulis -- 41

Tabel 7.1 Model kurikulum anak yang tidak mengalami gangguan kecerdasan -- 89

Tabel 7.2 Model kurikulum anak yang mengalami gangguan kecerdasan -89

Tabel 7.3 Contoh Modifikasi Kompetensi Dasar (KD) -- 90

Tabel 7.4. Contoh Modifikasi Indikator -- 90

Tabel 7.5. Contoh Modifikasi Materi pembelajaran -- 91

Tabel 7.6. Contoh Modifikasi Proses -- 91

Tabel 9.1 Contoh silabus siswa reguler -- 108

Tabel 9.2 Contoh modifikasi silabus bagi anak yang mengalami hambatan kecerdasan -- 108

Tabel 11.1. Format laporan Akademik Siswa Berkebutuhan Khusus (Rapor) -- 126 
DAFTAR FORMULIR

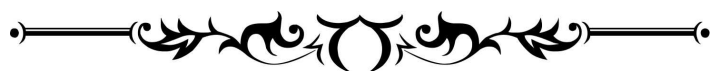

Formulir 4.1 Informasi Perkembangan Anak -- 42

Formulir 4.2 Data Orang Tua/Wali Siswa -- 44

Formulir 4.3 Daftar Anak Yang Terindikasi Berkelainan Dan Memerlukan

Pelayanan Khusus -- 46

Formulir 9.1 Contoh Rencana Perangkat Pembelajaran siswa reguler -- 109

Formulir 9.2 Contoh Modifikasi Rencana Perangkat Pembelajaran siswa yang mengalami hambatan kecerdasan -- 110

viii 


\section{DAFTAR GAMBAR}

.

Gambar 4.1 Skema PPI -- 47

Gambar 6.1. Pola Skema Pembelajaran -- 60

Gambar 7.1 Skema Implementasi model kurikulum -- 88 


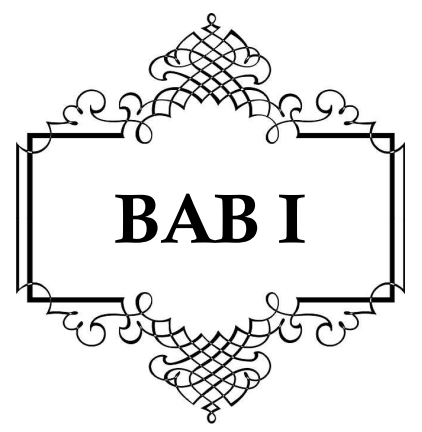

\section{PENDAHULUAN}

Setelah membaca bab ini pembaca diharapkan:

* Memahami hal-hal yang melatar belakangi pembahasan buku ini

* Mengetahui kepada siapa buku ini di tujukan

* Memahami ruang lingkup permasalahan yang dikaji dalam buku ini

* Memahami model kerangka pendekatan yang digunakan dalam penulisan buku ini

* Mengetahui pembahasan pada setiap bab yang dibahas dalam buku ini

\section{A. Latar Belakang}

Semenjak dikeluarkannya Undang-undang pendidikan nomor 12 tahun 1954 pendidikan bagi anak-anak yang memiliki kelainan fisik dan mental sudah terjamin secara hukum. Jaminan itu diberikan dalam bentuk sekolah bagi anak-anak penyandang disabilitas yang diakomodir oleh berbagai macam sekolah luar biasa. SLB-A untuk Tuna netra, SLB-B bagi tuna rungu-wicara, SLB-C untuk tuna grahita, SLB-D untuk tuna daksa, SLBE untuk tuna laras, SLB-G untuk tuna ganda. Jaminan pendidikan itu semakin menguat khususnya semenjak keluarnya program pemerintah tahun 1984 tentang program wajib belajar enam tahun. Imbas dari program tersebut menghendaki seluruh anak usia sekolah dasar wajib bersekolah dan menamatkan pendidikan minimal enam tahun. Berbagai program pendukungpun disusun, mulai dari pendirian sekolah baru, paket A, sekolah kecil hingga sekolah terbuka. Perubahan juga dirasakan oleh sekolah-sekolah luar biasa yang ada, dengan daya tampung yang terbatas maka pemerintah melebur SLB yang ada menjadi SDLB (Sekolah Dasar 
Luar Biasa), SMPLB (Sekolah Menengah Luar Biasa) dan SMALB (Sekolah Menengah Atas Luar Biasa).

Sekolah luar biasa yang pertama di Indonesia dalam bentuk lembaga untuk penyandang tuna netra yang bertujuan untuk penampungan dan latihan kerja terbimbing. Lembaga ini telah didirikan semenjak tahun 1901 di Kota Bandung yang diprakarsai oleh dr. Westhoff yang merupakan seorang dokter mata berkebangsaan belanda. (Sunardi, 2010:19)

Pada tahun 1994 muncullah kurikulum baru tentang Pendidikan Luar Biasa. Di dalam kurikulum yang baru, nama satuan PLB bukan lagi SLB tetapi menjadi SDLB (pendidikan umum tingkat SD selama 6 tahun), SLTPLB (pendidikan semi kejuruan setingkat SMP selama 3 tahun), dan SMALB (pendidikan kejuruan Setingkat SLTA). Dengan kurikulum baru, pada tingkat SLTLP dan SLTA, ALB yang mempunyai potensi akademik tinggi tampaknya harus didorong untuk berintegrasi di SMP umum, karena pada kedua jenjang pendidikan ini kurikulum PLB lebih banyak menyediakan pendidikan keterampilan. (Sunardi, 2010:26).

Perlindungan yang lebih luas terhadap anak yang memiliki kelainan fisik dan mental dengan lahirnya Undang-undang nomor 20 tahun 2003 tentang sistem pendidikan nasional membawa angin segar yang memiliki kelainan fisik, emosional, mental, intelektual, dan/atau sosial karena dalam undang-undang tersebut berhak memperoleh pendidikan khusus yang disebut dengan pendidikan inklusif. Selanjutnya disosialisasikan melalui surat edaran Dirjen Dikdasmen Depdiknas No. 380/C.C6/MN/2003 20 Januari 2003: "Setiap kabupaten/kota diwajibkan menyelenggarakan dan mengembangkan pendidikan inklusif di sekurang-kurangnya 4 (empat) sekolah yang terdiri dari: SD, SMP, SMA, SMK".(Budiyanto, 2013:8)

Kemudian pada tahun 2009 lahir lagi Permendiknas Nomor 70 tahun 2009 tentang Pendidikan Inklusif bagi peserta didik yang memiliki kelainan dan memiliki potensi kecerdasan dan/atau Bakat Istimewa, dinyatakan dalam pasal 2 dan pasal 3 yang berbunyi:

Pasal 2:

Pendidikan inklusif bertujuan:

a. Memberikan kesempatan yang seluas-luasnya kepada semua peserta didik yang memiliki kelainan fisik, emosional, mental, dan sosial, atau memili potensi kecerdasan dan/atau bakat istimewa untuk memperoleh pendidikan yang bermutu sesuia dengan kebutuhan kemampuannya;

b. Mewujudkan penyelenggaraan pendidikan yang menghargai keanekaragaman, dan tidak diskriminatif bagi semua peserta didik sebagaimana yang dimaksud pada huruf a. 
Pasal 3:

(1) Setiap peserta didik yang memiliki kelainan fisik, emosional, mental, sosila, atau memiliki potensi kecerdasan dan/atau bakat istimewa berhak mengikuti pendidikan secara inklusif pada satuan pendidikan tertentu sesuai dengan kebutuhan dan kemampuannya.

(2) Peserta didik yang memiliki kelainan sebagaimana yang dimaksud dalam ayat (1) terdiri atas:

a. Tunanetra;

b. Tuna rungu;

c. Tunawicara;

d. Tunagrahita;

e. Tunadaksa;

f. Tunalaras;

g. Berkesulitan belajar;

h. Lamban belajar;

i. Autis

j. Memiliki gangguan motorik;

k. Menjadi korban penyalahgunaan narkoba, obat terlarang dan zat adiktif lainnya;

l. tunaganda.

Sesuai dengan tujuan penyelenggaraan pendidikan inklusif di atas anak-anak yang mengalami hambatan tersebut dapat bersekolah bersama dengan anak-anak normal lainnya dalam satu sekolah. Konsep yang ditawarkan oleh pendidikan inklusif ini sendiri sangat mengakomodir kebutuhan dari ABK mulai dari adanya guru khusus yang disebut dengan GPK (Guru Pendamping Khusus), sarana dan prasarana yang disediakan khusus untuk mereka, seperti; jalur khusus, alat bantu pembelajaran, hingga kurikulum dan evaluasi yang disesuaikan dengan kemampuan mereka.

Berbicara tentang kurikulum dan evalusi pembelajaran untuk anak berkebutuhan khusus tentu akan disesuaikan hingga kesetiap mata pelajaran, tak terkecuali pelajaran Pendidikan Agama Islam.

Pendidikan Agama Islam (PAI) merupakan salah satu mata pelajaran yang masuk ke dalam kurikulum Nasional. Oleh karenanya, mata pelajaran PAI selalu ada dalam kurikulum sekolah umum, baik Sekolah Negeri atau Swasta. Harapannya mata pelajaran PAI mampu mendorong siswa untuk menumbuhkan karakter dan kepribadian yang luhur. Pendidikan Islam berupaya mengembangkan individu yang utuh yang dapat mewarisi nilainilai Islam. (Haidar Putra Daulay, 2004:222) 
Pelajaran Agama Islam di sekolah diapaparkan dalam beberapa aspek, antara lain aspek; Fiqih (Hukum Islam), Akidah (Mentauhidkan Allah swt), Al-Qur'an (pokok-pokok ajaran Islam), Hadits (Sunnah-sunnah Rasulullah saw), dan Sejarah (Kisah Inspiratif).

Pendidikan Islam idealnya yang tujuan dan dasar-dasarnya berdasarkan kepada ruh Islam yang dituangkan Allah dalam Al-Quran dan dicontohkan Rasul dalam Hadits. Pendidikan yang berdasarkan kepada Realita masyarakat dan lingkungan yang mengitarinya, juga berdasarkan kepada nilai yang bersumber dari Agama dan kebudayaannya.(Depdiknas, 2004:32)

Hakikat manusia dalam pandangan Allah swt adalah sama, yakni sebagai makhluk ciptaannya. Allah tidak memandang kaya, miskin, tua, muda, pejabat, atau masyarakat biasa, yang dapat membedakan antara makhluk hidup ini adalah ketaqwaan kita kepada Allah swt. Seperti yang dikutip dalam Qs. Al Hujurat (49) ayat 13;

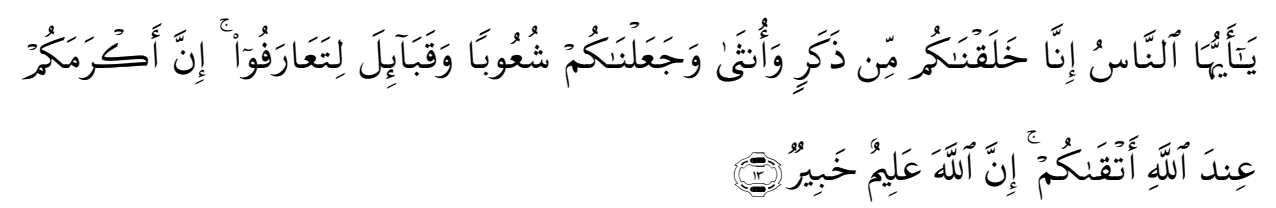

Artinya: Hai manusia, Sesungguhnya Kami menciptakan kamu dari seorang laki-laki dan seorang perempuan dan menjadikan kamu berbangsa-bangsa dan bersuku-suku supaya kamu saling kenalmengenal. Sesungguhnya orang yang paling mulia diantara kamu disisi Allah ialah orang yang paling taqwa diantara kamu. Sesungguhnya Allah Maha mengetahui lagi Maha Mengenal.

Sejarah Islam mencatat sebuah peistiwa tentang bagaimana menghargai orang yang memiliki keterbatasan untuk diperhatikan, sebagaimana ketika ibnu Ummi Maktum, seorang buta datang kepada Rasulullah saw. seraya berkata: "Berilah aku petunjuk ya Rasulallah." Pada waktu itu Rasululllah sawsedang menghadapi para pembesar kaum musyrikin Quraisy. Beliau berpaling dari Ibnu Ummi Maktum dan tetap menghadapi pembesar-pembesar Quraisy. Ibnu Ummi Maktum berkata: "Apakah yang saya katakan ini mengganggu tuan? " Rasulullah menjawab: "Tidak." Kemudian Allah menegur Rasulullah saw dengan turunnya Alqur'an surat Abasa (80) ayat 1-10; 


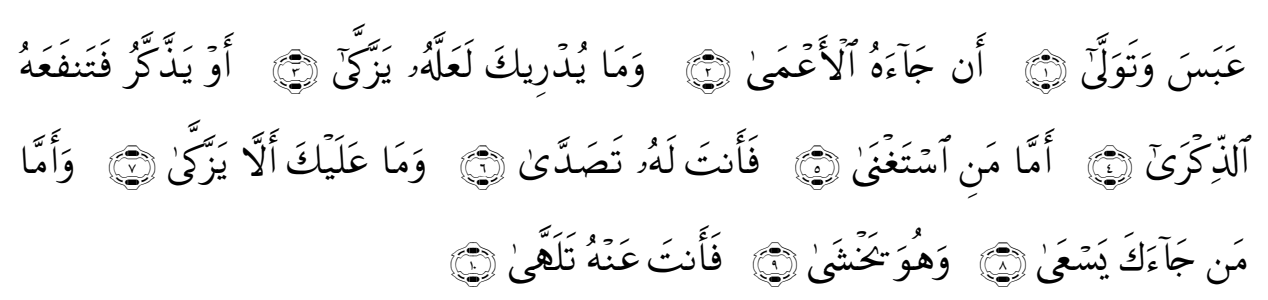

Artinya: 1). Dia (Muhammad) bermuka masam dan berpaling, 2). Karena telah datang seorang buta kepadanya, 3). Tahukah kamu barangkali ia ingin membersihkan dirinya (dari dosa), 4). Atau Dia (ingin) mendapatkan pengajaran, lalu pengajaran itu memberi manfaat kepadanya? 5). Adapun orang yang merasa dirinya serba cukup, 6). Maka kamu melayaninya,7). Padahal tidak ada (celaan) atasmu kalau Dia tidak membersihkan diri (beriman), 8). Dan Adapun orang yang datang kepadamu dengan bersegera (untuk mendapatkan pengajaran).9. Sedang ia takut kepada (Allah), 10). Maka kamu mengabaikannya.

Dalam kaitanya dengan pendidikan inklusif, posisi mata pelajaran Agama Islam dalam memaksimalkan potensi anak berkebutuhan khusus sangat berpengaruh terhadap kehidupan beragama yang akan diamalkan oleh mereka, hal ini bertujuan agar mereka tidak selalu dipandang sebelah mata dalam beramal dan condong di labeli "dimaafkan" karena kekurangan yang mereka miliki.

Untuk itulah guru agama sebagai orang yang berperan untuk mengarahkan dan menjadi teladan bagi mereka sehingga dalam mengamalkan ibadah yaumiyah dengan ketaatan dan memahami ajaran agama dengan shahih.

\section{B. Tujuan}

Buku ini adalah pembahasan tentang menciptakan suasana pembelajaran yang efektif bagi anak berkebutuhan khusus dalam mata pelajaran pendidikan Agama Islam di sekolah-sekolah inklusif. Buku ini juga hendaknya menjadi pedoman bagi guru bidang studi Agama Islam dalam menyusun rencana dan melaksanakan kegiatan pembelajaran di kelas. Selama ini guru agama di sekolah-sekolah umum kurang memahami secara konkrit tentang bagaimana bentuk pembelajaran bagi anak berkebutuhan khusus, guru-guru agama yang mengajar di sekolah inklusif cenderung menyamakan proses pembelajaran dan penilain seperti anak normal lainnya, dan kalaupun dilakukan modifikasi hanya pada tahap evaluasi dengan modifikasi nilai saja artinya tidak tidak dilakukan secara 
bertahap sesuai dengan proses seperti identifikasi dan asesmen anak berkebutuhan khusus dengan tenaga ahli yang yang dibutuhkan, seperti melihat hasil tes, rekomendasi psikolog, rekomendasi guru pendamping khusus, masukan orang tua dan informasi terkait lainnya. Maka dari itu buku ini disusun untuk membantu guru mulai dari pengenalan sekolah inklusif, anak berkebutuhan khusus, merencanakan pembelajaran hingga melakukan evaluasi akhir.

\section{Ruang Lingkup}

Dalam buku ini khusus membahas tentang pembelajaran Pendidikan Agama Islam yang akan memaparkan tentang teori dan praktek pendidikan inklusif yang ada di indonesia sehingga pembaca memahami tentang landasan pelaksanaan pendidikan inklusif di sekolah-sekolah ataupun kelas dimana anak berkebutuhan khusus berada. Disamping itu juga pemahaman tentang karakteristik anak berkebutuhan khsusus itu sendiri akan dipaparkan supaya guru dalam menyusun rencana pelaksanaan pembelajaran agar dapat membantu proses akademik anak berkebutuhan khusus hingga melakukan evaluasi pembelajaran tersebut selesai.

Setelah pembaca mengetahui konsep pendidikan inklusif dan karakteristik anak berkebutuhan khusus maka pembahasan tentang pembelajaran Agama Islam yang praktis mengenai anak berkebutuhan khusus secara bertahap akan dijelaskan sehingga guru dapat mengaplikan dalam kegiatan pembelajaran di kelas inklusif.

\section{Kerangka Pendekatan}

Buku ini mengadopsi pendekatan yang digunakan dalam konsep pengembangan pendidikan inklusif yang dikeluarkan oleh Direktorat Jendral Pendidikan Khusus dan Layanan Khusus. Dimana buku ini membantu menyebarluaskan pembelajaran yang khusus tentang materi pelajaran Pendidikan Agama Islam secara teori dan praktek, agar para guru-guru yang belum memahami secara keseluruhan dari praktek pengembangan pendidikan inklusif dalam materi pelajaran pendidikan Agama Islam itu sendiri.

\section{E. Struktur Buku}

Pada bab I buku ini akan membahas tentang Pendahuluan, adapun sub tema yang akan diuraikan antara lain; Latar belakang, tujuan, ruang lingkup, kerangka pendekatan, dan struktur buku.

Pada bab II buku ini berbicara tentang Pendidikan Inklusif, adapun sub tema yang akan diuraikan antara lain; konsep pendidikan inklusif, 
landasan pendidikan inklusif, prinsip-prinsip pendidikan inklusif, profil pembelajaran sekolah inklusif, dan permasalahan pendidikan inklusif di Indonesia.

Pada bab III buku ini mengungkapkan tentang Anak berkebutuhan Khusus, adapun sub tema yang akan diuraikan antara lain; Konsep dasar anak berkebutuhan khusus, dan karakteristik anak berkebutuhan.

Pada bab IV buku ini akan membahas tentang identifikasi dan asesmen anak berkebutuhan khusus, adapun sub tema yang akan diuraikan antara lain; Identifikasi anak berkebutuhan khusus, dan asesmen anak berkebutuhan khusus.

Pada bab $\mathrm{V}$ buku ini akan membahas tentang layanan pendidikan anak berkebutuhan khusus, adapun sub tema yang akan diuraikan antara lain; Intelektual di bawah rata-rata, gangguan prilaku, dan autisme.

Pada bab VI buku ini akan membahas tentang Pembelajaran Pendidikan Agama Islam, adapun sub tema yang akan diuraikan antara lain; konsep Pendidikan Agama Islam, landasan historis pendidikan agama islam, ruang lingkup pendidikan agama islam, dan isu-isu pendidikan agama islam.

Pada bab VII buku ini akan menguraikan tentang Disain kurikulum PAI untuk ABK, adapun sub tema yang akan diuraikan antara lain; Konsep dasar kurikulum, asas-asas kurikulum, fungsi kurikulum, jenis-jenis kurikulum, dan implementasi kurikulum PAI untuk ABK.

Pada bab VIII buku ini memberikan gambaran tentang Guru untuk Anak Berkebutuhan Khusus, adapun sub tema yang akan diuraikan antara lain; konsep dasar guru, tugas pokok guru, dan kompetensi guru.

Pada bab IX buku ini akan membahas tentang perencanaan pembelajaran $\mathrm{ABK}$, adapun sub tema yang akan diuraikan antara lain; konsep dasar perencanaan pembelajaran, implementasi perencanaan dalam sekolah inklusif.

Pada bab X buku ini akan menguraikan tentang konsep dasar media pembelajaran untuk Anak Berkebutuhan Khusus, adapun sub tema yang akan diuraikan antara lain; konsep dasar media pembelajaran untuk ABK, fungsi media pembelajaran untuk ABK, jenis-jenis media Pembelajaran untuk $\mathrm{ABK}$, dan kriteria pemilihan media pembelajaran untuk ABK.

Pada bab XI buku ini akan menguraikan tentang evaluasi pembelajaran anak berkebutuhan khusus, adapun sub tema yang akan diuraikan antara lain; konsep dasar evaluasi pembelajaran $A B K$, tujuan evaluasi pembelajaran, fungsi evaluasi pembelajaran prinsip evaluasi pembelajaran, jenis-jenis evaluasi pembelajaran, teknik evaluasi pembelajaran, implementasi laporan akademik ABK. 
Pada bab XII buku ini akan menguraikan tentang kesimpulan dari keseluruhan pembahasan buku ini. 


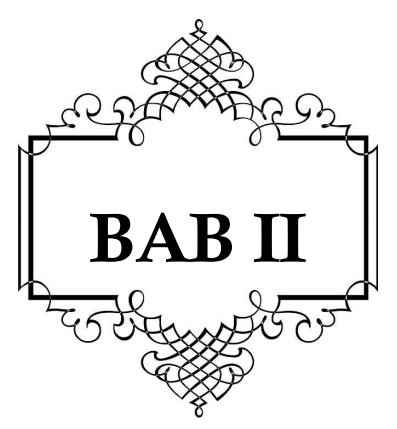

\section{PENDIDIKAN INKLUSIF DI INDONESIA}

Setelah membaca bab ini pembaca diharapkan:

* Memahami konsep pendidikan inklusif di Indonesia

* Mengetahui nilai-nilai apa saja yang melandasi lahirnya pendidikan inklusif di indonesia

* Memahami prinsip-prinsip yang melandasi terciptanya pendidikan inklusif

\# Mengetahui profil lembaga pendidikan inklusif

* Memahami isu-isu yang hangat seputar penerapan pendidikan inklusif di Indonesia

\section{A. Konsep Dasar Pendidikan Inklusif}

Pendidikan inklusif menurut Staub dan Peck (1995) mengemukan bahwa penempatan anak berkelaianan tingkat ringan, sedang, dan berat secara penuh di kelas reguler. Sementara menurut Sapon-Shevin (1995) menyetakan bahwa pendidikan inklusif sebagai sistem layanan pendidikan mempersyaratkan agar semua anak berkelaianan dilayanai di sekolahsekolah terdekat, di kelas reguler bersama-samateman seusianya. Kemudian Freiberg (1995) mengemukakan bahwa melalui pendidikan inklusif peserta didik berkebutuhan khusus didik bersama-sama peserta didik pada umumnya (normal) untuk mengoptimalkan potensi yang dimilikinya. (Direktorat PKLK, 2013: 12)

Dalam Permendiknas nomor 70 tahun 2009 tentang pendidikan pendidikan inklusif diartikan sebagai sistem penyelenggarakan pendidikan 
yang memberikan kesempatan kepada semua peserta didik yang memiliki kelainan dan potensi kecerdasan dan/atau bakat istimewa untuk mengikuti pendidikan atau pembelajaran dalam lingkungan pendidikan secara bersama-sama dengan peserta didik pada umumnya.

Pendidikan inklusif ini memberikan akses pendidikan formal di sekolah-sekolah umum seperti; SD sederajat, SMP sederajat, dan SMA sederajat kepada anak-anak yang memiliki kelainan baik fisik seperti; tunanetra, tunarungu, tunawicara, tunadaksa dan juga kepada anak-anak yang mengalami kelainan secara mental seperti; tunagrahita, tunalaras, autis, dan lain sebagainya. Begitu juga akses pendidikan inklusif ini juga menerima anak-anak yang memiliki potensi kecerdasan yang luar biasa dan anak-anak yang memiliki bakat istimewa dari siswa lainnya.

Inklusi adalah suatu sistem ideologi dimana secara bersama-sama tiap-tiap warga sekolah, yaitu masyarakat, kepala sekolah, guru, pengurus yayasan, petugas administrasi sekolah, para siswa, dan orang tua menyadarai tanggung jawab bersama mendidik semua siswa sedemikian sehingga mereka berkembang secara optimal sesuai potensi mereka (Direktorat PKLK, 2014:9). Maka dari itu seorang anak berkebutuhan khusus tidak dapat serta merta dimasukkan kedalam kelas reguler tanpa adanya pemahaman dari warga sekolah tentang hakikat dari pendidikan inklusif ini.

Bergabungnya anak berkebutuhan khusus dengan anak-anak normal di sekolah reguler menggunakan 3 model, diantaranya; mainstream, integrasi, dan inklusi. (Direktorat PKLK, 2014:10) Model mainstream dilakukan terhadap anak-anak yang tidak mengalami sakit yang berdampak kepada pengurangan kemampuan kognitifnya, seperti anakanak yang memiliki kecacatan sensori menggunakan alat bantu dan anak tuna daksa, kemudian juga kepada anaka-anak yang mengalami sakit asma, epilepsi dan lainnya.

Model integrasi yaitu menggabungkan anak-anak yang berkebutuhan khusus dengan anak normal lainnya dalam satu kelas ketika mengikuti pelajaran-pelajaran yang dapat mereka ikuti, dan untuk pelajaran akdemis yang tidak bisa mereka ikuti, akan mereka dapatkan di kelas yang berbeda dengan anak-anak normal dengan materi pengganti pula.

Pada model inklusi ini memberikan kesempatan yang lebih luas lagi kepada seluruh anak-anak yang memiliki kelaianan dan/ atau bakat istimewa untuk mengikuti pendidikan secara bersama-sama dengan anak normal lainnya dalam satu lingkungan sekolah sesuai dengan kebutuhan dan kemampuan yang mereka miliki.

Dengan hadirnya Pendidikan inklusif yang ramah terhadap anak berkebutuhan khusus ini memberikan ruang kepada mereka untuk 
menunjukkan eksistensi mereka baik dalam bidang akademik maupun ekstrakurikuler.

\section{B. Landasan Pendidikan Inklusif}

Penyelenggaraan pendidikan inklusif di Indonesia memiliki berbagai landasan yang mendasarinya antara lain terdiri dari; landasan filosofi, yuridis, dan berbagai komitmen yang telah digalakkan oleh masyarakat dunia. Adapun diantara landasan tersebut ialah;

1. Landasan Filosofis

1. Bhineka Tunggal Ika, Indonesia terdiri dari berbagai macam latar belakang suku, budaya, adat, keturunan, keyakinan yang yang terlibat dalam memperjuangkan kemerdekaan Republik Indonesia sehingga seperti saat sekarang. Bhineka Tunggal Ika yang berarti Berbeda-beda tetapi tetap satu. Makna dari tulisan ini sangat penting sekali untuk membangun sekolah yang dapat menampung setiap anak dengan berbagai latar belakang kebutuhan.

2. Pandangan Agama islam sendiri bahwa manusia tidak ada bedanya di mata Allah, akan tetapi yang membedakan seseorang adalah derajat ketaqwaannya. Sebagaiman dalam qs. Al Hujurat (13) ayat ke 49.

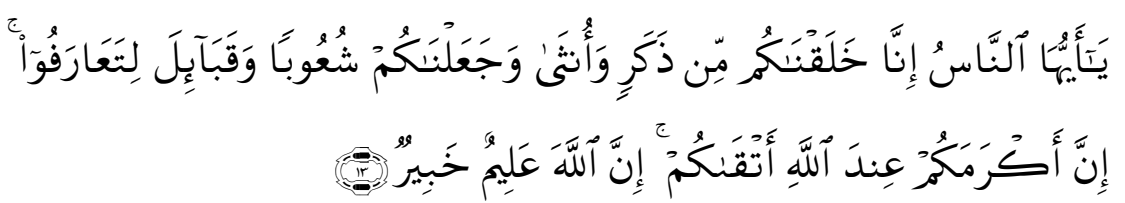

Artinya: Hai manusia, Sesungguhnya Kami menciptakan kamu dari seorang laki-laki dan seorang perempuan dan menjadikan kamu berbangsa-bangsa dan bersuku-suku supaya kamu saling kenal-mengenal. Sesungguhnya orang yang paling mulia diantara kamu disisi Allah ialah orang yang paling taqwa diantara kamu. Sesungguhnya Allah Maha mengetahui lagi Maha Mengenal.

3. Pandangan Universal tentang hak azazi manusia yang menyatakan bahwa "setiap manusia mempunyai hak untuk hidup layak, hak pendidikan, hak kesehatan, hak pekerjaan.

4. Pendidikan inklusif didasari semangat terbuka untuk merangkul semua kalangan dalam pendidikan

5. Pendidikan inklusif merupakan implementasi pendidikan multikultural yang dapat membantu peserta didik mengerti, menerima, serta menghargai orang lain yang berbeda suku, budaya, nilai kepribadian, dan keberfungsian fisik maupun psikologis. 
2. Landasan Yuridis

1. Undang-undang Dasar 1945 yang telah diamandemen, yang termuat dalam pasal 31.

ayat (1) : setiap warga negara berhak mendapat pendidikan

ayat (2) : setiap warga negara mempunyai hak yang sama untuk memperoleh pendidikan dasar dan pemerintah wajib membiayainya

2. Undang-undang nomor 4 tahun 1997 tentang Penyandang Cacat.

Pasal 5 : setiap penyandang cacat mempunyai hak dan kesempatan yang sama dalam segala aspek kehidupan dan penghidupan

3. Undang-undang nomor 23 tahun 2002 tentang Perlindungan Anak.

Pasal 48: pemerintah wajib menyelenggarakan pendidikan dasar minimal 9 (sembilan) tahun untuk semua anak

Pasal 49 : negara, pemerintah, keluarga, dan orang tua wajibmemberikan kesempatan yang seluas-luasnya kepada anak untuk memperoleh pendidikan.

4. Undang-Undang Dasar nomor 20 tahun 2003 tentang Sistem Pendidikan Nasional, pasal 5.

ayat (1) : setiap warga negara mempunyai hak yang sama untuk memperoleh pendidikan yang bermutu

ayat (2) : warga negara yang mempunyai kelaianan fisik, emosional, mental, intelektual, dan/ atau sosial berhak memperoleh pendidikan khusus

ayat (3) : warganegara di daerah terpencil atau terbelakang serta masyarakat adat yang terpencil berhak memperoleh pendidikan layanan khusus

ayat (4) : warga negara yang memiliki potensi kecerdasan dan bakat istimewa berhak memperoleh pendidikan khusus

5. Surat Edaran Direktorat Jendral Pendidikan Dasar dan Menengah Kementrian Pendidikan Nasional nomor 380/C.C6/MN/2003, tanggal 20 Januari 2003.

"setiap kabupaten/kota diwajibkan menyelenggarakan dan mengembangakan pendidikan inklusif di sekurang-kurangnya 4 (empat) sekolah yang terdiri dari: SD, SMP, SMA, SMK"

6. Peraturan Menteri Pendidikan Nasional nomor 70 tahun 2009 tentang Pendidikan Inklusif bagi peserta didik yang memiliki kelainan dan/ atau bakat istimewa

7. Peraturan Pemerintah nomor 17 tahun 2010 tentang pengelolaan dan penyelenggarakan pendidikan pasal 127-142 
3. Komitmen

1. Deklarasi Hak Azazi Manusia, 1948 (Declaration of Human Rigth)

2. Konvensi Hak Anak, 1989 (Convention on the Rights of the child)

3. Konferensi Dunia tentang Pendidikan untuk semua (World Conference on Education for All)

4. Resolusi Perserikatan Bangsa-bangsa nomor 48/96 tahun 1993 tentang persamaan kesempatan bagi Orang Kerkelainan (the standard rules on the equalization of opportunities for persons with disabilitas)

5. Pernyataan Salamanca atau yang lebih dikenal dengan "Salamanca Statement and Framework for Action on Special Needs Education" di Spnayol, 1994

6. Deklarasi Bukittinggi, 1995

7. Komitmen Dakar tentang pendidikan untuk semua, 2000 (the Dakar Commitment on Education for All)

8. Deklarasi Bandung, 2004 (Indonesia Menuju Pendidikan Inklusif)

Dari berbagai landasan di atas terlihat begitu banyak argumen yang dapat dipegangi dalam menyelenggarakan pendidikan inklusif, sehingga tidak ada alasan lain menjadikan pendidikan inklusif ini tidak diadopsi dan di laksanakan disekolah-sekolah umum baik negeri ataupun sekolah yang dinaungi yayasan swasta.

\section{Prinsip-prinsip Pendidikan Inklusif}

Sebelum menyelenggarakan pendidikan inklusif di sekolah-sekolah umum hendaknya kita lihat beberapa prinsip yang yang harus diperhatikan dalam penerapan pendidikan ini, antara lain; (Direktorat PKLK, 2013: 13)

1. Prinsip pemerataan dan peningkatan mutu

Melalui pendidikan inklusif pemerintah melakukan pemerataan pendidikan sehingga dapat diakses oleh setiap peserta didik yang memiliki usia sekolah atau wajib belajar 9 (sembilan tahun). Begitu juga dengan konsep peningkatan mutu pendidikan di negeri ini, dengan pendekatan yang bervariasi yang bisa menyentuh pada semua anak dan menyentuh pada semua anak dan menghargai perbedaan.

2. Prinsip kebutuhan individual

Setiap anak memiliki kemampaun yang berbeda-beda tak terkecuali anak berkebutuhan khusus, maka dari itu diharapkan guru menyesuikan pembelajaran sesuai dengan kebutuhan dan kondisi peserta didik tersebut

3. Prinsip kebermakanaan 
Pendidikan yang menghadirkan empati, saling menghargai, ramah, dan menerima keberagaman merupakan konsep dari pendidikan inklusif yang harus diuraikan oleh seluruh warga sekolah

4. Prinsip keberlanjutan

Penyelnggaraan pendidikan inklusif dilaksanakan secara berkelanjutan pada semua jenjang pendidikan mulai dari Taman kanak-kanak hingga perguruan tinggi

5. Prinsip keterlibatan

Dalam melaksanakan pendidikan inklusif harus melibatkan seluruh stakeholder pendidikan sehingga dapat terlaksananya pendidikan secara optimal.

Penyelenggaraan pendidikan pada umumnya mengacu pada satu tujuan materi dan metode yang sama tanpa memandang kebutuhan peserta didik. Mereka hanya disuguhkan materi yang baku dari buku cetak yang dijadikan pedoman oleh guru, sehingga satu-satunya tuntutan yang harus dipenuhi siswa adalah tercapainya setiap indikator pembelajaran sesuai yang telah ditargetkan, yang menjadi barometer keberhasilan seorang peserta didik. Bagi peserta didik yang tidak memenuhi kriteria ketuntasan belajar maka akan diberikan program remedial, jika hal ini tidak juga berdampak dalam hasil belajara maka peserta didik tersebut dinyatakan tidak berhasil alias tinggal kelas. Pola-pola pendidikan seperti inilah yang dirobah oleh pendidikan inklusif yang lebih mengutamakan prinsip discovering ability (proses menemukan potensi) peserta didik oleh guru sehingga pembelajaran diarahkan menjadi students centered (berpusat kepada siswa). Dengan pola ini maka siswa akan menjadi fokus utama guru dalam mengekplorasi anak tersebut dari sisi akademik.

\section{Profil Pembelajaran Sekolah Inklusif}

Berikut ini dipaparkan profil penyelenggaraan pendidikan inklusif yang baik sehingga menjadi referensi dalam mengoptimalkan peran lembaga pendidikan, diantara profil tersebut disampaikan dalam buku Modul pelatihan pendidikan Inklusif yang disusun oleh Budiyanto, dkk mengutip pendapat oleh Sapon-Shevin, berisi; (Direktorat PKLK, 2013: 13)

1. Pendidikan Inklusi berarti menciptakan dan menjaga komunitas kelas yang hangat, menerima keanekaragaman, dan mengahargai perbedaan.

2. Mengajar kelas yang heterogen memerlukan perubahan pelaksanaan kurikulum yang mendasar. Pembelajaran dikelas inklusi akan bergeser dari pendekatan pembelajaran kompetitif yang kaku, mengacu materi tertentu, ke pendekatan pembelajaran 
kooperatif yang melibatkan kerjasama antarsiswa, dan bahan belajar tematik.

3. Pendidikan inklusi berarti menyiapkan dan mendorong guru untuk mengajar secara interaktif. Dimana guru dapat mengembangkan potensi siswa dengan terjadinya pola belajar antara siswa dengan siswa lainnya saling belajar, mengajar dan bekerjasama diantara mereka yang menumbuhkan keaktifan dalam proses dan mereka bertanggungjawab terhadap diri mereka sendiri.

4. Pendidikan inklusi berarti penyediaan dorongan bagi guru dan kelasnya secara terus menerus dan penghapusan hambatan yang berkaitan dengan isolasi profesi. Dalam proses pendidikan inklusif guru dituntut untuk dapat bekerjasama bersama dengan profesi yang lain diantaranya seperti, psikolog, guru pendamping khusus, kalangan profesional lainnya.

5. Pendidikan inklusi berarti melibatkan orang tua secara bermakna dalam proses perencanaan. Dalam menyusun program individu peserta didik yang tergolong anak berkebutuhan khusus sangat diperlukan sekali peran serta dari orang tua begitu juga dalam membimbing langsung anak ketika berada di rumah masingmasing.

Ketika hal-hal yang telah kita sebutkan tadi dapat terlaksana maka rancang bangun penyelenggaraan pendidikan khusus akan dapat terwujud sehingga terciptanya pendidikan yang diidamkan oleh anak berkebutuhan khusus. Untuk tahap selanjutnya ada beberapa hal yang perlu diperhatikan pihak-pihak terkait dalam penyelenggaraan pendidikan inklusif antara lain;

1. Sekolah harus menyediakan kondisi kelas yang hangat, ramah, menerima keanekaragaman dan menghargai perbedaan.

2. Guru dituntut melakukan kolaborasi dengan profesi atau sumberdaya lain dalam perencanaan, pelaksaan dan evaluasi

3. Guru dituntut melibatkan orangtua secara bermakna dalam proses pendidikan

4. Kepala sekolah dan guru (yang nantinya akan menjadi GPK=Guru Pendamping Khusus) harus mendapatkan pelatihan bagaimana menjalankan sekolah inklusi

5. GPK mendapatkan pelatihan teknis memfasilitasi anak ABK

6. Asesmen di sekolah dilakukan untuk mengetahui anak ABK dan tindakan diperlukan

7. Mengidentifikasi hambatan berkaitan dengan kelainana fisik, sosial dan maslah lainnya terhadap akses dan pembelajaran 
8. Melibatkan masyarakat dalam melakukan perencanaan dan monitoring pendidikan bagi semua anak. (Direktorat PKLK, 2013: 16)

Seluruh hal diatas hendaknya dilakukan dengan tindakan lanjutan untuk memberikan pemahaman hakikat dari pendidikan inklusif ini kepada masing-masing pemangku elemen agar pendidikan inklusif ini berjalan dengan baik.

\section{E. Permasalahan Pendidikan Inklusif di Indonesia}

Sebenarnya pendidikan inklusif ini sudah lama dikembangkan dinegara-negara maju seperti Amerika Serikat dan Eropa seperti yang dituturkan oleh suyanto dan Mudjito dalam buku mereka yang berjudul Masa Depan Pendidikan Inklusif: Suyanto dan Mudjito, 2013:7)

"Di AS dan Eropa, Program Inklusif ini sudah berlansung lama dan sukses membangun kesetaraan . infrastruktur di sana juga sangat mendukung. Misalnya semua gedung-gedung bertingkat dan fasilitas publik di sana selalu menyediakan tempat parkir khusus untuk masyarakat "disable." Lokasinya paling strategis, paling depan, paling gampang diakses, paling lebar, tidak ada penghalang dan bisa langsung menuju ke pintu utama. Biasanya ada gambarnya simbol kursi roda, berwarna biru atau kuning. Jika orang normal parkir ditempat itu, langsung kena denda terbesar! dia dinggap melakukan pelanggaran berat.

Ruangan tolilet juga begitu, dibuat dengan ukuran lain, lebih besar, lebih dekat dengan akses pintu keluar masuk, handle pintunya melintang, sehingga memudahkan membuka dan menutup pintu. Papan-papan petunjuk dengan simbol kursi roda ada di ruang-ruang publik juga tersebar di manamana.

Di kota-kota besar Tiongkok, fasilitas publik yang acceptable terhadap orang-orang berkebutuhan khusus juga makin lengkap. Di hampir semua pedestrian, tempat pejalan kaki di jalur-jalur protokol selalu dilengkapi dengan tanda khusus untuk tuna netra. Pola lantai trotoarnya dibuat berbeda dengan ekstrem. Dibuat garis-garis melintang, agar kalau mereka yang tidak bisa melihat bisa tetap menyusuri jalan itu dengan baik dan aman.

Di Airport juga begitu. Ada jalur-jalur keramik lantainya dibuat lebih besar berpola-pola patah-patah. Maksudnya, agar mereka yang tuna netra bisa memanfaatkan jalur itu dengan baik dan aman. 
Kota paris, perancis, yang dibagi ke dalam kota tua dan kota baru juga memberikan penghargaan yang mat tinggi bagi penderita cacat. Hampir semua gedung bertingkat itu bisa diakses oleh orang dengan kursi roda, tanpa harus memperoleh bantuan orang lain. Karena ada satu lantai, dimana gedung-gedung itu connect atau terhubung satu dengan yang lain. Artinya sejak awal perencanaan gedung sudah ada persyaratan yang diberikan oleh tata kota atau semacam pemilik otoritas dalam mendirikan bangunan, selain harus melalui analisa dampak lingkungaan, juga harus ada connecting floor, antara satu gedung dengan yang lain. Dengan begitu setiap orang yang berkebutuhan khusus yang hendak bepergian antara gedung satu ke gedung yang lain, tidak mengalami kesulitan. Tidak ada tanggga naik turun yang membahayakan keselamatan mereka.

Itu semua membuktikan bahwa masyarakat di banyak penjuru dunia menempatkan orang orang berkebutuhan khusus itu dalam posisi yang normal. Memberikan ruang kemandirian untuk lebih leluasa dalam beraktifitas sebagaimana manusia normal. Dan mereka juga merasa lebih berdaya, lebih mandiri, lebih bebas untuk menentukan pilihan hidup dan optimis menjalani kehidupan. Mereka punya hak untuk mendapatkan keleluasaan seperti orang normal"

Kisah di atas masih berbanding terbalik dengan kondisi pendidikan inklusif di negeri ini. Sebagai contoh ketika disediakan sebuah fasilitas yang memudahkan sirkulasi para penyandang disabilitas berupa lift yang dikhususkan dengan tanda kursi roda disebuah supermarket, yang terjadi bukannya lift tersebut disibukkan dengan sirkulasi masyarakat yang memiliki hambatan fisik akan tetapi pemuda yang normal yang keluar dengan riang gembira. Begitu juga dengan jalur antrian khusus yang disediakan dengan tanda yang sama, masyarakat kita masih menggunakan jalur tersebut dengan alasan antrian panjang dan lain sebagainya. Upaya standarisasi bangunan yang mengakomodir para penyandang disabilitas patut diacungi jempol, akan tetapi tidak dibarengi dengan kesadaran dari masyarakat tentang peruntukkan fasilitas tersebut jauh dari harapan. Melakukan penyadaran akan pemakaian fasilitas-fasilitas yang tidak diperuntukkan untuk mereka menjadi pr yang mesti kita lakukan secara bersama-sama, yang tentunya dengan upaya penanaman semenjak usia dini yang akan didapat dari orang tua kepada anaknya, sangsi sosial dan peran sekolah.

Sekolah inklusif sudah sejak lama diselenggarakan di Indonesia, akan tetapi belum semua daerah melaksanakan pendidikan inklusif ini. Diantara 
Provinsi yang telah mendeklarasikan diri menjadi penyelenggara Pendidikan Inklusif diantaranya; Pada tahun 2012 dimulai oleh Provinsi Kalimantan Selatan, kemudian pada tahun 2013 dilanjutkan oleh Provinsi Aceh, Sumatra Selatan, Jawa Barat, Sulawesi Selatan, dan DKI Jakarta. Pada tahun 2014 Provinsis Sulawesi Tenggara mendeklarasikan diri dengan disusul oleh Provinsi Sumatra Barat, Provinsi Bali dan Provinsi Lampung. Kemudian pada tahun 2015 hanya Provinsi Sumatera Utara yang tercatat mendeklarasikan diri. Baru pada tahun 2016 Nusa Tenggara Timur dan Jawa Timur menjadi Provinsi yang mendeklarasikan penyelenggara pendidikan Inklusif (diolah dari berbagai sumber).

Dari data yang diambil oleh Direktorat Pembinaan PK-LK Pendidikan Dasar persentase sekolah yang menyelenggarakan pendidikan inklusif untuk jenjang SD hanya $0,39 \%$ dan pada tingkat SMP hanya 0,25\%.(Direktorat PKLK, 2013: 23). Hal senada juga diungkapkan oleh Direktur Jenderal Pendidikan Dasar dan Menengah (Dirjen Dikdasmen) merilis data bahwa dari 514 kabupaten/kota di seluruh tanah air, masih terdapat 62 kabupaten/kota yang belum memiliki SLB. Lebih lanjut disampaikan bahwa dari 1,6 juta anak berkebutuhan khusus di Indonesia, baru 18 persen yang sudah mendapatkan layanan pendidikan inklusi. Sekitar 115 ribu anak berkebutuhan khusus bersekolah di SLB, sedangkan ABK yang bersekolah di sekolah reguler pelaksana Sekolah Inklusi berjumlah sekitar 299 ribu (blog Kemdikbud, 2017).

Disamping belum semua sekolah yang menyelenggarakan pendidikan inklusif, ketersediaan Guru Pendamping Khusus juga menjadi sorotan tajam di sekolah-sekolah yang telah ditunjuk dalam sekolah penyelenggara pendidikan inklusif. Kebanyakan sekolah mengatasi cara ini dengan tenaga bantuan dari guru SLB yang berada satu wilayah dengan sekolah tersebut, yang kehadiran guru referal tersebut juga tidak dapat dipastikan alias kalau dibutuhkan dan dipanggil oleh pihak sekolah.

Permasalahan lain yang tidak kalah adalah pengetahuan warga sekolah tentang penyelenggaraan pendidikan inklusif masih sangat minim dan bahkan asal jawab saja, begitu juga dengan faktor orang tua yang kurang menerima nilai anaknya disamakan dengan nilai anak-anak berkebutuhan khusus.

Segala permasalahan di atas menjadi tanggung jawab kita semua untuk menyadarkan orang-orang disekeliling kita akan pemahaman tentang sekolah inklusif, maka dari itu buku ini bermaksud memberikan secuil pemahaman kepada kita bahwa perjuangan menyadarkan lingkungan akan dampak dari penyelenggaraan pendidikan inklusif masih sangat diperlukan. 


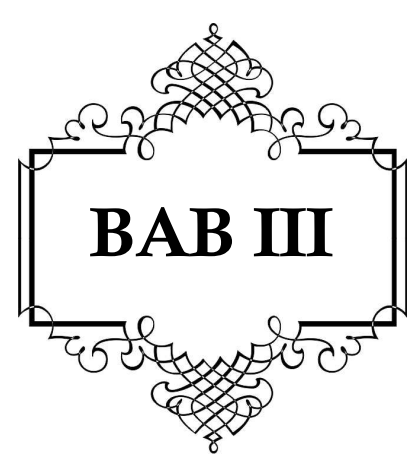

\section{ANAK BERKEBUTUHAN KHUSUS}

Setelah membaca bab ini pembaca diharapkan:

* Memahami konsep dasar Anak Berkebutuhan Khusus

* Memahami karakteristik Anak Berkebutuhan Khusus

* Mampu mengenali ciri-ciri anak berkebutuhan khusus yang berada dilingkungan sekitar

\section{A. Konsep Dasar Anak Berkebutuhan Khusus}

Pada mulanya istilah berkebutuhan khusus muncul dari dari pendidikan khusus yang diberikan kepada para peserta didik yang mengalami kecacatan fisik maupun psikologis. Sehingga kepada mereka diberikan materi pelajaran yang dimodifikasi agar mampu mengikuti pembelajaran di sekolah yang khusus seperti di SLB, SDLB, dan lainnya.

Menurut Ganda Sumekar (2009:2) Anak Berkebutuhan Khusus adalah anak-anak yang mengalami penyimpangan, kelainan atau ketunaan dalam segi fisik, mental, emosi dan sosial, atau gabungan dari hal-hal tersebut sedemikian rupa sehingga mereka memerlukan pelayanan pendidikan yang khusus, yang disesuaikan dengan penyimpangan, kelainan, atau ketunaan mereka.

Pendidikan inklusif yang ditawarkan pemerintah merupakan bentuk dari lembaga pendidikan khusus yang diamanahkan oleh undang-undang Sistem Pendidikan Nasional nomor 20 tahun 2003. Direktoral PSLB menyebutkan (2010:16) yang membutuhkan layanan pendidikan khusus, Peserta didik yang karena internalnya mengalami kecacatan/ kelaianan 
(disability) seperti (tungarahita, tunarungu, tunagrahita, tunadaksa, anak berbakat dan berkecerdasan istimewa, autis, dan sebagainya).

Dari pengertian di atas dapat disimpulkan bahwa Anak Berkebutuhan Khusus adalah Anak yang Cacat secara mental, fisik, emosional maupun sosial yang mampu dididik pada tingkat satuan pendidikan tertentu sesuai dengan kebutuhan dan kemampuannya. Namun yang perlu diperhatikan bahwa tidak semua anak yang mengalami kecacatan fisik ataupun psikologis dikategorikan kepada anak yang berkebutuhan khusus yang nantinya diberikan modifikasi pembelajaran akan tetapi Anak berkebutuhan khusus yang dimaksudkan ialah anak-anak yang dianggap mampu mengikuti pelajaran disekolah inklusif setelah dilakukan identifikasi dan asesmen oleh tenaga profesional.

\section{B. Klasifikasi Anak Berkebutuhan Khusus}

Ganda Sumekar (2009:19-20) memaparkan klasifikasi anak berkebutuhan khusus, anatar lain:

1) Aspek Psikologis

Dilihat dari kemampuan intelektual anak berkebutuhan khusus dapat dikelompokkan sebagai berikut :

a. Lambat Belajar (Slow Learner)

Menurut hasil seminar tentang masalah cacat mental yang dilaksanakan di Magelang pada tanggal 18 Agustus 1975, yang dimaksud dengan lambat belajar adalah anak yang berada di ambang batas normal dengan IQ antara 75-85. mereka memerlukan pelayanan sosial dan pendidikan secara khusus. Dengan perhatian dan pelayanan khusus, mereka akan dapat menyelesaikan program pendidikan dasar. Bagi anak yang malas hamper pada tiap kelas dijalani dalam waktu 2 tahun.

b. Mampu Didik (Debil)

Tingkat intelegensi anak dari golongan ini sudah tergolong rendah, namun masih dapat dididik secara khusus dengan program dan metoda yang khusus pula. IQnya antara 50-70. tingkatan intelegensinya sama, seperti anak lain usia 7-12 tahun. Paling tinggi dapat menyelesaikan pendidikan setaraf dengan sekolah dasar sampai kelas IV atau kelas V. untk menyelesaikan sampai jenjang kelas VI memerlukan perjuangan dan pembinaan dari seua pihak yang terkait.

c. Mampu latih (Embisil)

Secara pedagogis tingkat intelegensi anak ini sudah tergolong rendah, tidak mempu menerima pendidkan secara akademis. Sesuai dengan 
kemampuannya mereka ahanya dapat menerima pendidikan secara kebiasaan (habitual). Lebih dititik beratkan pada pendidikan latihan keterampilan khusus. IQnya antara 25-50. tingkatan ini sama dengan anak apada umumnya usia 3 sampai 7 tahun. Paling tinggi dapat menyelesaikan tingkat pendidikan di Sekolah dasar sampai kelas I atau kelas II (sekedar bisa membaca, menulis dan berhitung/3 $\mathrm{R}$ yang sederhana sekali).

d. Perlu rawat (idiot)

Ditinjau dari segi pedagogis tingkat intelegensi anak kelompok ini terlalu rendah. Tidak mampu menerima pendidikan secara akademis, juga tidak mampu menerima pendidikan keterampilan. Perkembangan mentalnya sangat sedikit, tidak bisa memahami sesuatu dan sukar dilatih sesuatu kecakapan, IQ kelompok anak ini kurang dari 25. Tingkat intelegensinya sama dengan anak pada umumnya yang berusia 1-3 tahun.

\section{2) Aspek Fisiologis}

Jenis kebutuhan khusus peserta didik terdiri atas kebutuhan khusus fisik dan/atau mental, perilaku dan social. Kebutuhan fisik meliputi :

a. Gangguan penglihatan, adalah kerusakan atau cacat yang mengakibatkan seseorang tidak dapat melihat (buta) atau orang yang kurang daya penglihatannya.

b. Gangguan pendengaran, adalah kerusakan atau kelainan pendengaran yang mengakibatkan seseorang tidak dapat mendengar (tuli) atau orang yang kurang daya pendengarannya.

c. Gangguan fisik dan kesehatan, adalah kelainan/cacat tubuh yang mengakibatkan kurang berfungsinya kemampuan gerak, termasuk motorik, sensorik dan mobilitas.

Hal yang perlu mendapat pertimbangan dalam menetapkan program yang akan diberikan kepada anak berkebutuhan khusus. Ganda Sumekar (2009:22) menyebutkan beberapa problem penyerta yang dialami anak berkebutuhan khusus adalah sebagai berikut: selain mereka mengalami kelainan fisik, namun tidak seluruhnya kelaianan fisik saja, tetapi ada gejala lain, hal ini diakibatkan adanya kerusakan fungsi fisik itu sendiri. Seperti:

a. Retardasi mental. Akibat adanya kerusakan di otak maka akan mempengaruhi kemampuan mental intelektual, keterbatasan untuk belajar, penyelesaian sosoal dan tingkah laku, sehingga kemampuannya lebih rendah dibanding dengan anak pada umumnya. 
b. Gangguan pendengaran. Hal ini terjadi karena kerusakan sentral/tidak jarang anak cacat otak mengalami hambatan pendengaran, bukan tuli tetapi persepsi pendengarannya yang terganggu, ia mendengar tetapi tidak mengerti apa yang didengarnya.

c. Gangguan penglihatan. Terjadi akibat adanya ketidakseimbangan otototot mata, misalnya mata jerang/juling (strabismus).

d. Gangguan taktil dan kinestetik. Anak berkebutuhan khusus ada yang mengalami kesulitan untuk mengamati sesuatu melalui fungsi taktilnya demikian pula fungsi kinestetiknya, dengan demikian meraka mengalami kesulitan dalam merasakan gerakannya sendiri.

e. Gangguan body image. Gangguan ini adalah kesulitan untuk merasakan adanya bagian tubuh sendiri tanpa melihat atau memegang, hal ini akan mengalami kesulitan untuk melakukan suatu gerakan.

f. Gangguan persepsi. Gangguan ini kesulitan untuk mengolah rangsangan melalui penglihatan (visuil), pendengaran (auditory), dan rasa raba (tactile) yang diterimanya. Mereka mengalami kesulitan di dalam konsep bentuk, ruang, warna, bunyi dan sebagainya.

g. Gangguan literalisasi. Gangguan ini mengalami kesulitan dalam menggunakan anggota tubuh yang dominan. Hal ini terjadi akibat adanya kerusakan yang terjadi pada hemisphere dominannya.

h. Gangguan epilepsy (kejang-kejang). Gangguan seperti ini yang dialami oleh anak berkebutuhan khusus merupakan suatu serangan ulang dari kelainan pusat susunan syaraf yang terjadi.

\section{3) Aspek Sosiologis}

Yang utama sekali harus dikerjakan oleh guru dalam menghadapi anak berkebutuhan khusus yaitu membangkitkan sosialisasi anak. Anak dianjurkan saling mengenal satu sama lainnya, yang penting membina anak sebagai anggota kelompok. Mereka harus bertingkah laku sesuai dengan harapan orang lain, mencoba menyesuaikan tingkah laku.

Sebagian besar proses sosialisasi adalah dengan cara meniru menyamakan dan mencontoh tingkah laku orang tuanya, gurunya dan kawan-kawannya. Dalam sosialisasi ini bukan berarti orang tua bukan harus terus menerus melayani anak berkebutuhan khusus, akan tetapi beberapa kecakapan yang dapat dilakukan anak diserahkan kepada anak itu sendiri.

Kecakapan sosialisasi yang dimaksud adalah merupakan pergaulan antara anak dengan orang lain. Ganda Sumekar (2009:24) mengatakan kepada anak dapat ditanamkan tingkah laku yang mesti ditaati seperti : 
a. Tidak mengganggu orang lain;

segala tingkah laku anak itu hanya berdasarkan kepuasan hati pada dirinya sendiri. Apa yang dilakukan hanya untuk kenikmatan diri sendiri, dia tidak akan peduli dengan keinginan orang lain. Kadangkadang dengan adanya anak lain hanya untuk kesenangannya sendiri. Walaupun anak itu bersama-sama tetapi perhatiannya tetap pada kepuasan diri sendiri.

b. Tidak menyakiti orang lain;

Suatu barang dapat berubah menjadi suatu permainan. Anak akan bergaul sesamanya karena peraturan permainan itu. Bagaimana melaksanakan peraturan itu dilakukan menurut cara-cara sendiri dari masing-masing anak. Anak tidak akan memperhatikan tingkah laku orang lain, yang dia amati ialah peraturan tersebut. Sepanjang aturan itu tidak berubah tetap anak melaksanakan peraturan itu.

c. Tidak mengambil milik orang lain.

Peraturan permainan atau objek diluar dirinya mulai difikirkan untuk kepentingan bersama sehingga apa yang dapat dikatakan baik tergantung kepada pendapat orang lain. Keinginan harapan orang lain menjadi ukuran penyesuaian dalam pergaulan. Kelancaran penyesuaian sosial tergantung kepada kemampuan intelektual dan anggapan orang tua atau masyarakat terhadap anak tersebut.

Demikan uraian mengenai tahapan kemampuan sosialisasi bagi beberapa anak yang terhambat penyesuaian sosialnya sehingga menjadi kendala. Ganda Sumekar juga mneybutkan (2009:23-24) sebab-sebab adanya penyimpangan sosial, sebagai berikut:

a. Keadaan di dalam diri sendiri.

Keadaan diri anak cacat mengakibatkan penyimpangan penyesuaian social karena kecacatannya, tubuh/fisiknya yang cacat atau keadaan sensorisnya, hal ini akan mempengaruhi kepribadiannya.

b. Konflik dan proses perkembangannya.

Di dalam menjalani proses perkembangn, tiap anak harus melalui beberapa macam komplikasi yang pada umumnya dapat dilalui dengan lancer dan sukses. Tetapi juga yang mengalami gangguan atau hambatan dalam mengjhadapi konflik-konflik tersebut, sehingga tidak dapat dilampaui dengan memuaskan dan menimbulkan gangguangangguan emosi dan tingkah laku. 
c. Sebab-sebab lingkungan.

Anak hidup di dalam tiga dimensi lingkungan yang mempengaruhi perkembangan kepribadiannya. Yaitu :

1. Lingkungan keluarga

2. Lingkungan sekitarnya

3. Lingkungan sekolah.

Dari sebab-sebab yang dialami oleh anak tersebut dalam penyesuaian sosialnya dapat dikelompokkan sebagai berikut :

a. Anak yang mengalami penyimpangan sosial

Pada golongan anak-anak ini gangguan terletak pada perkembangan perasaan dan sikap-sikap sosialnya. Menurut Cruickshank (Ganda Sumekar, 2009:24-25) anak-anak ini dapat di bagi dalam beberapa kelompok, yaitu :

1. Anak-anak yang disebut semi socialized, yaitu mereka yang dapat mengadakan hubungan sosial yang terbatas

2. Anak-anak yang dengan tingkatan sosialisasi yang primitif. Golongan ini terganggu perkembangan sosialnya pada level yang masih rendah.

3. Anak-anak yang tidak memiliki kemampuan untuk belajar sosialisasi.

Reiss (Ganda Sumekar,2009:25) , membedakan anak dalam tiga type psokologis, yaitu :

1. Relatively integrated delinquent

Anak-anak pada kelompok ini relative mempunyai penyesuaian yang baik dan hanya menunjukkan tingkah laku yang menyimpang dalam bentuk-bentuk tertentu, misalnya menyendiri.

2. Delinquent dengan ego control yang lemah

Anak-anak ini adalah anak yang merasa tidak aman, tidak mempunyai kepercayaan diri sendiri, dan merasa dirinya rendah. Anak-anak ini juga menunjukkan tingkah laku yang agresif dan sikap permusuhan.

3. Delinquent dengan hambatan pada super ego control

Pada anak ini sikap sosial dan tingkah laku sosial tidak berkembang, cirri-ciri anak ini adalah ketidak matangan dalam aspek emosi.

b. Anak yang terganggu emosinya

Anak ini anak-anak yang sakit mentalnya, pada anak ini dapat diadakan pengelompokan berdasarkan tingkatan gangguan, yaitu :

1. Anak yang mengalami gangguan emosi yang bersifat sementara saja dan dapat teratasi dengan sendirinya. 
2. Anak-anak yang mengalami gangguan emosi sehingga mempengaruhi tingkah laku mereka. gangguan yang mereka alami dapat mempengaruhi prestasi belajar mereka. mereka masih dapat mengikuti pelajaran, tetapi memerlukan bantuan dari pembimbing/konselor.

3. Anak-anak dengan gangguan yang lebih parah lagi sehingga praktis mereka sudah tidak dapat mengikuti program sekolah dan penyesuaian sosial dan mereka terancam. Pada golongan ini yang pertama diperlukan psikoterapy.

4. Anak-anak yang mengalami gangguan mental yang sudah parah sekali sehingga penyesuaian sosialnya terganggu, mereka memerlukan bantuan perawatan khusus.

5. Anak dengan tingkatan sosialisasinya yang primitive. Golongan ini terganggu perkembangan sosialnya pada level yang masih rendah.

6. Anak-anak yang tidak memiliki kemampuan untuk belajar social behavior (tingkah laku sosial).

4. Klasifikasi dan etiologi anak berkebutuhan khusus

Anak berkebutuhan khusus dapat dibedakan berdasarkan jenis kelainannya (Ganda Sumekar, 2009:25-28). Tiap-tiap jenis kelainan dapat dibagi lebih lanjut berdasarkan berat ringannya masing-masing sebagai berikut:

a. Kelainan penglihatan

Kelaianan penglihatan yang paling berat ialah buta, yang ringan terdiri dari yang rabun dekat, rabun jauh, astigmatisme dan sebagainya. Kriterianya terletak apda penangkapan cahaya. Yang disebut buta ialah yang tidak dapat menangkap cahaya sama sekali. Orang yang masih dapat melihat jari yang bergerak kurang dari satu meter jauhnya dari matanya, demikian juga yang mempunyau visual acuity (ketajaman penglihatan) kurang dari 20/200feet belum buta, akan tetapi dalam pendidikannya dimasukkan ke gelas Braille (untuk yang buta).

Penglihatan yang normal dapat melihat cahaya yang punya gelombang antara 380 nanometer (violet) dan 760 nanometer (merah).

b. Kelainan pendengaran

Kelainan pendengaran yang paling berat ialah tuli sama sekali. Dalam bahasa sehari-hari orang yang hanya dapat menangkap suara keras disebut tuli (pekak). Dalam pendidikan luar biasa yang disebut tuli hanyalah yang tidak dapat menagkap suara sama sekali, sekalipun dibantu dengan alat bantu dengar (hearing aid). Anak yang masih dapat mendengar suara sekalipun suara keras atau dibantu dengan alat bantu 
dengar (hearing aid) disebut kurang pendengaran. Suara keras oleh mereka terdengar lemah. Jadi berkurang selisih ini disebut kehilangan pendengaran. Keras lemahnya suara dihitung dengan satuan decibel (disingkat $\mathrm{dB}$ ). decibel adalah ratio antara tekanan suara dengan tekanan yang terjadi pada ambang pendengaran orang normal. Jadi 20 deciBel adalah 10 kali tekanan pada ambang pendengaran, $40 \mathrm{~dB}$ adalah 100 kali, $60 \mathrm{~dB}$ adalah 100 kali, $120 \mathrm{~dB}$ adalah sejuta kali. Orang yang sedang bercakap-cakap menggunakan suara antara 50-70 dB, suara berbisik $20 \mathrm{~dB}$, suara petir ialah $120 \mathrm{~dB}$. Satuan nada ialah Hert (jumlah getaran dalam jarak satu meter). Pendengaran normal dapat menangkap nada antara 20 sampai $20.000 \mathrm{~Hz}$, suara yang paling jelas ialah antara 1000 hingga $4000 \mathrm{~Hz}$.

c. Kelainan Bicara

Kelainan bicara yang paling keras adalah bisu/gagu, yang ringan terdiri dari berbagai kelainan. Adapun batas antara anak-anak yang mengalami kelainan bicara dengan yang normal adalah anakanak/orang yang cacat bicara memaksa pemerhati/lawan bicara untuk memperhatikan cara bicaranya dalam menangkap isi pembicaraannya. Dalam kaitannya dalam kelainan bicara berbagai kalainan yang akan kita temukan di lapangan antaranya stuttering (gagap), disartria (kelainan artikulasi), afasia (kehilangan bahasa), kelambatan berbicara dibanding dengan usianya (delayed speech).

Anak yang berbicaranya sepotong-potong misalnya bola diucapkan ia (short memory span), dan tidak jarang kita temukan anak dengan autism yaitu yang mempuanyai karakteristik bicara khas.

d. Kelainan kecerdasan

Kalainan kecerdasan merupakan suatu keadaan dimana seseorang mengalami perkembangan dan kemampuan intelektual yang terbelakang. Keterbelakangan mental menyangkut tingkatan operasional dari kecerdasan seseorang. Terman mengemukakan bahwa keterbelakangan mental dapat ditafsirkan menurut tingkatan keterbelakangannya :

1. Idiot, yaitu mereka yang mempunyai IQ antara 0-20 atau 25 kelompok ini disebut totally dependent, karena tidak dapat belajar memelihara diri sendiri dan hanya memerlukan perawatan (perlu rawat).

2. Imbesil, yaitu anak yang memiliki IQ antara 20/25-50/55. Mereka dikatakan mampu latih (trainable), karena mereka tidak dapat 
belajar membaca, menulis dan hanya dapat dilatih dalam kebiasaan sehari-hari.

3. Moron atau debil, mereka yang mempunyai IQ antara 50/5570/75. Mereka masih dapat diberi pelajaran setaraf SD dan disebut mampu didik (educable).

4. Slow learner atau border line mempunyai IQ di bawah rata-rata yaitu 75 atau 85. Mereka ini tidak termasuk terbelakang mental dan juga tidak termasuk normal.

e. Kelainan tubuh atau fisik

Kelainan yang Nampak pada anak kelainan tubuh ini yang mencolok adalah masalah gerak yaitu adanya kelainan daripada gerak. Kata lain dari anak dari kelompok ini adalah tunadaksa yang meliputi :

1. Orthopedically handicapped, yaitu anak-anak yang mempunyai deformity yaitu mengganggu fungsi normal dari tulang, otot atau persendian.

2. Neurological handicapped, yaitu cacat tubuh yang disebabkan oleh gangguan-gangguan fungsi syarat karena adanya gangguan di otak.

\section{f. Kelainan penyesuaian sosial}

Anak-anak dengan gangguan emosi dan perkembangan sosial, mereka dimasukkan dalam golongan yang sulit menyesuaikan diri dengan norma-norma atau kenyataan. Tingkah laku yang mereka lakukan misalnya mencuri, merusak, menyakiti, dan sebagainya. Dalam golongan anak-anak ini termasuk anak-anak yang disebutjuvenille delinquent yang artinya perbuatan-perbuatan yang dilakukan dianggap melanggar hukum dan dilakukan oleh anak-anak yang belum mencapai kedewasaan.

Anak-anak dengan gangguan perkembangan sosial termasuk di dalamnya adalah anak autism, yaitu anak yang memiliki ciri asik dengan dirinya sendiri. Disamping itu ada juga anak yang memiliki gangguan pemusatan perhatian dan hiperaktifitas, dalam bahasa inggris dikenal dengan ADHD (attention devicite and Hiperactivity disorder).

Faktor-faktor yang terjadi pada prenatal, natal dan post natal, dapat mengakibatkan seseorang dilahirkan dengan mengalami kelainan/luar biasa. Pengaruh keturunan disebut factor endogen diwariskan melalui kromosom dan sel keturunan. Hal-hal yang bukan keturunan banyak, misalnya: infeksi, virus, anoxia, anemia ibu, blood incompatibility dan sebagainya. 
Data-data mengenai jumlah anak berkebutuhan khusus banyak ragamnya, salah satu diantaranya mengatakan kira-kira 12\% jumlah anak sekolah adalah anak berkebutuhan khusus. (Ganda Sumekar, 2009:29) 


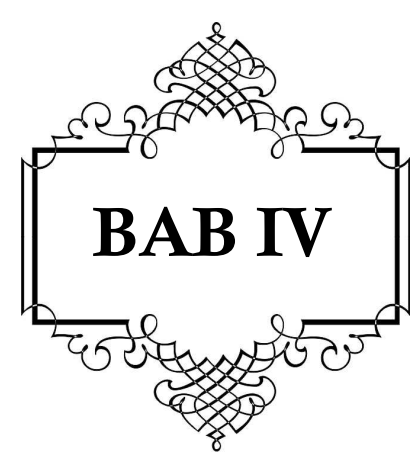

\section{IDENTIFIKASI DAN ASESMEN ANAK BERKEBUTUHAN KHUSUS}

Setelah membaca bab ini pembaca diharapkan:

* Memahami konsep dasar dari idenfikasi terhadap anak berkebutuhan khusus yang

$\$$ memahami cara melakukan Identifikasi Anak Berkebutuhan Khusus

* Memahami konsep dasar dari Asesmen Anak Berkebutuhan Khusus

* Memahami cara melakukan Identifikasi Anak Berkebutuhan Khusus

\section{A. Identifikasi Anak Berkebutuhan Khusus}

Identifikasi berarti penentu atau penetapan identitas seseorang. Menurut buku pedoman umum penyelenggaraan pendidikan inklusif (Direktorat PKLK, 2013:19) Identifikasi dimaknai sebagai proses penyaringan (screening) untuk menentukan jenis kebutuhan khusus peserta didik. Dengan kata lain melakukan identifikasi merupakan cara untuk mengenal kondisi peserta didik apakah termasuk kepada anak berkebutuhan khusus atau tidak, hingga penentuan jenis berkebutuhan khusus manakah peserta didik tersebut dapat diketahui dengan melakukan identifikasi yang benar. Identifikasi sendiri sebenarnya dilakukan oleh tenaga profesional seperti dokter atau psikolog, namun kegiatan identifikasi ini sendiri dapat dilakukan oleh orang tua, guru yang tentunya 
memahami kondisi anak berkebutuhan khusus menggunakan instrumen standar atau yang disusun sendiri oleh guru atau tenaga ahli

Dalam prosesnya, mengidentifikasi anak berkebutuhan khusus sebelum dimulainya kegiatan pembelajaran sangat penting dilakukan sebelum melakukan asesmen. Menurut McLoughlin (Budiyanto, 2013:33) bahwa identifikasi merupakan kegiatan awal yang mendahului asesmen. Dalam arti kata kedua kegiatan ini saling terkait untuk memberikan masukan kepada guru dalam menyusun program pengajaran individual.

Adapun tujuan dari identifikasi ini antara lain:

1) Penjaringan (Screening), yaitu suatu kegiatan identifikasi yang berfungsi untuk menandai dan menetapkan anak-anak yang memiliki kondisi kelainansecara fisik, mental, sosial dan/atau emosi serta menunjukkan gejala-gejala perilaku yang menyimpang dari perilaku anak pada umumnya. Misalnya anak yang dengan gangguan penglihatan secara nyata dapat dilihat kerusakan fungsi penglihatannya.

2) Pengalihtanganan (Referal), yaitu kegiatan identifikasi yang dilakukan bertujuan untuk pengalihtanganan (Referal) ke tenaga profesi lainnya yang berkompeten di bidangnya seperti; dokter, terapis, psikolog, konselor, perawat, dan profesi lainnya.

3) Klasifikasi (Classification), yaitu kegiatan identifikasi yang dilakukan untuk tujuan menentukan atau menetapkan apakah anak tersebut tergolong kebutuhan khusus yang memang memiliki kelainan kondisi fisik, mental, intelektual, sosial dan/atau emosional serta gejala-gejala perilaku menyimpang dari perilaku anak pada umumnya.

4) Perencanaan pembelajaran (Instructional Planning), yaitu kegiatan identifikasi bertujuan untuk keperluan penyusunan program pembelajaran individual dasarnya hasil dari identifikasi.

5) Pemantauan kemajuan belajar (Monitoring pupil progress), yaitu digunakan untuk mengetahui apakah program pembelajaran khusus yang diberikan berhasil atau tidak dalam meningkatkan kemampuan anak (Budiyanto, 2013:35-36).

Setelah mengetahui tujuan dari identifikasi anak berkebutuhan khusus, maka langkah selanjutnya ialah melakukan identifikasi terhadap siswa dengan menggunakan alat identifikasi (Budiyanto, 2013:46-54) sebagai berikut: 
Tabel 4.1 Alat Identifikasi Anak Berkebutuhan Khusus

Nama Sekolah

Kelas

Diisi tanggal

Nama Petugas

Guru Kelas

\begin{tabular}{|c|c|c|c|c|c|c|c|}
\hline \multirow[t]{2}{*}{ Gejala Yang Diamati } & \multicolumn{7}{|c|}{$\begin{array}{l}\text { Nama Siswa Yang Diamati } \\
\text { (Berdasarkan Nomor Urut) }\end{array}$} \\
\hline & 1 & 2 & 3 & 4 & 5 & 6 & dst \\
\hline \multicolumn{8}{|l|}{ 1. Gangguan Penglihatan } \\
\hline $\begin{array}{l}\text { 1. Gangguan Penglihatan (low } \\
\text { vison); } \\
\text { a. Kurang melihat (Kabur) tidak } \\
\text { mampu mengenali orang pada jarak } \\
6 \text { meter }\end{array}$ & & & & & & & \\
\hline $\begin{array}{l}\text { b. Kesulitan mengambil benda kecil di } \\
\text { dekatnya }\end{array}$ & & & & & & & \\
\hline $\begin{array}{l}\text { c. Tidak dapat menulis mengikuti garis } \\
\text { lurus }\end{array}$ & & & & & & & \\
\hline $\begin{array}{l}\text { d. Sering meraba dan tersandung } \\
\text { waktu berjalan }\end{array}$ & & & & & & & \\
\hline $\begin{array}{l}\text { e. Bagian bola mata yang hitam } \\
\text { berwarna keruh/ bersisik/kering }\end{array}$ & & & & & & & \\
\hline f. Mata bergoyang terus & & & & & & & \\
\hline $\begin{array}{l}\text { g. Peradangan hebat pada kedua bola } \\
\text { mata }\end{array}$ & & & & & & & \\
\hline h. Kerusakan nyata pada kedua bola & & & & & & & \\
\hline $\begin{array}{l}\text { 2. Tidak Melihat (Tunanetra } \\
\text { Total) } \\
\text { a. Tidak dapat membedakan cahaya }\end{array}$ & & & & & & & \\
\hline 2. Gangguan Pendengaran (Tunarun & & & & & & & \\
\hline $\begin{array}{l}\text { 1. Kurang Pendengaran (hard of } \\
\text { hearing) } \\
\text { a. Sering memiringkan kepala dalam } \\
\text { usaha mendengar }\end{array}$ & & & & & & & \\
\hline b. Banyak perhatian terhadap getaran & & & & & & & \\
\hline $\begin{array}{l}\text { c. Tidak ada reaksi terhadap } \\
\text { bunyi/suara di dekatnya }\end{array}$ & & & & & & & \\
\hline $\begin{array}{l}\text { d. Terlambat dalam perkembangan } \\
\text { bahasa }\end{array}$ & & & & & & & \\
\hline
\end{tabular}




\begin{tabular}{|l|l|l|l|l|l|l|l|}
\hline e. $\begin{array}{l}\text { Sering menggunakan isyarat dalam } \\
\text { berkomunikasi }\end{array}$ & & & & & & & \\
\hline f. $\begin{array}{l}\text { Kurang atau tidak tanggap kalau } \\
\text { diajak berbicara }\end{array}$ & & & & & & & \\
\hline $\begin{array}{l}\text { i. Tuli (deaf) } \\
\text { Tidak mampu mendengar }\end{array}$ & & & & & & & \\
\hline
\end{tabular}

\begin{tabular}{|c|c|c|c|c|c|c|c|}
\hline \multirow[t]{2}{*}{ Gejala Yang Diamati } & \multicolumn{7}{|c|}{$\begin{array}{l}\text { Nama Siswa Yang Diamati } \\
\text { (Berdasarkan Nomor Urut) }\end{array}$} \\
\hline & 1 & 2 & 3 & 4 & 5 & 6 & $\mathrm{dst}$ \\
\hline \multicolumn{8}{|l|}{ 3. Tunagrahita } \\
\hline $\begin{array}{ll} & \text { 1. Kecerdasan } \\
\text { a. Ringan } \\
\text { a. Memiliki IQ 50-70 (dari WISC) }\end{array}$ & & & & & & & \\
\hline $\begin{array}{l}\text { b. Masih mampu membaca, menulis } \\
\text { dan berhitung sederhana }\end{array}$ & & & & & & & \\
\hline $\begin{array}{l}\text { c. Masih mampu membaca, menulis, } \\
\text { dan berhitung sederhana }\end{array}$ & & & & & & & \\
\hline d. Tidak dapat berfikir secara abstral & & & & & & & \\
\hline Perilaku adaptif & & & & & & & \\
\hline $\begin{array}{l}\text { a. Kurang perhatian terhadap } \\
\text { lingkungan }\end{array}$ & & & & & & & \\
\hline $\begin{array}{l}\text { b. Sulit menyesuaikan diri dengan } \\
\text { situasi (interaksi sosial) }\end{array}$ & & & & & & & \\
\hline b. Sedang & & & & & & & \\
\hline a. Memiliki IQ 25-50 (dari WISC) & & & & & & & \\
\hline b. Tidak dapat berfikir secara abstral & & & & & & & \\
\hline $\begin{array}{l}\text { c. Hanya mampu membaca kalimat } \\
\text { tunggal }\end{array}$ & & & & & & & \\
\hline $\begin{array}{l}\text { d. Mengalami kesulitan dalam } \\
\text { berhitun sekalipun sederhana }\end{array}$ & & & & & & & \\
\hline Perilaku adaptif & & & & & & & \\
\hline $\begin{array}{l}\text { a. Perkembangan interaksi dan } \\
\text { komunikasinya terlambat }\end{array}$ & & & & & & & \\
\hline 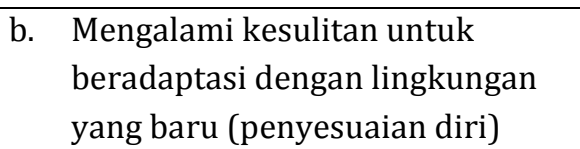 & & & & & & & \\
\hline
\end{tabular}




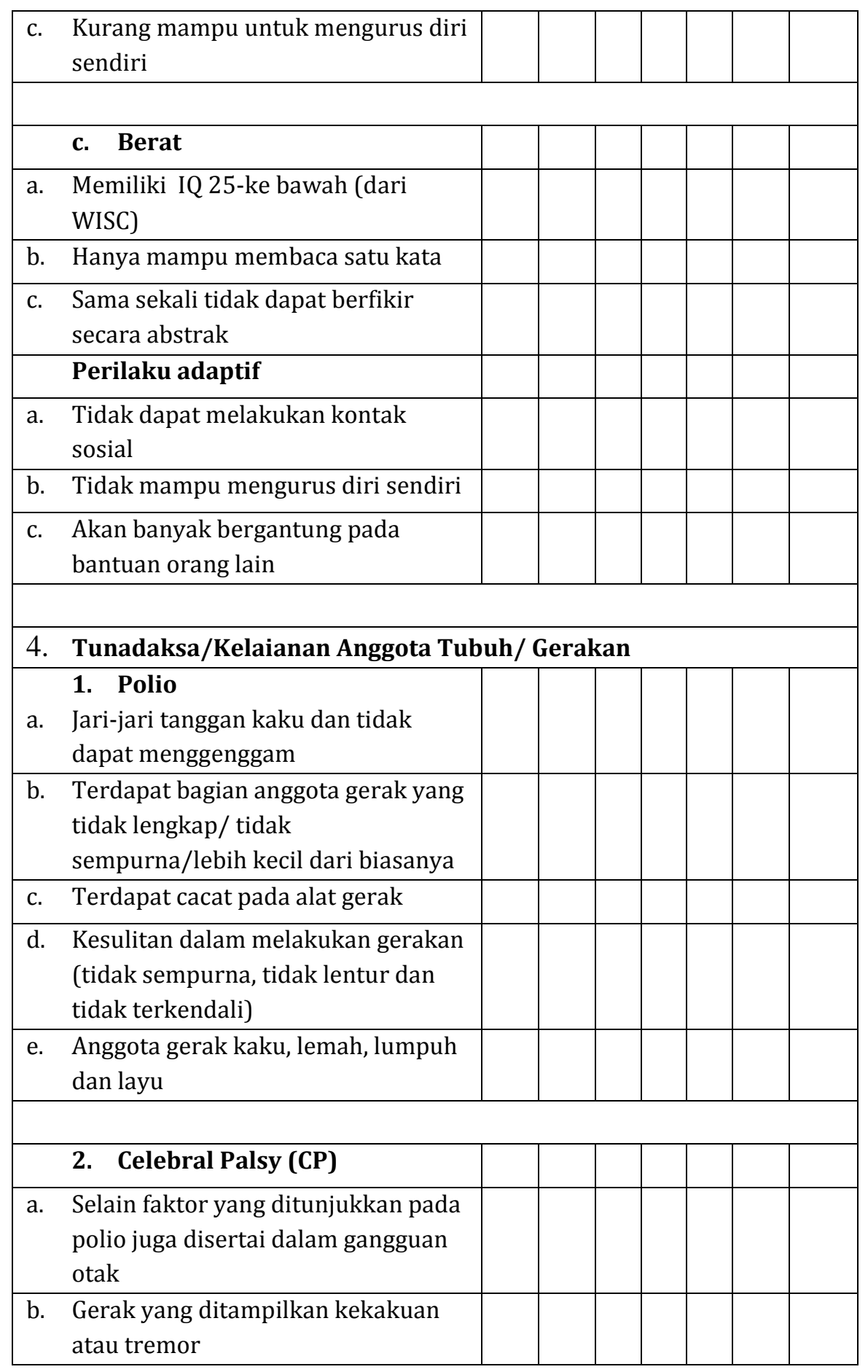




\section{Gejala Yang Diamati}

Nama Siswa Yang Diamati (Berdasarkan Nomor Urut)

\begin{tabular}{l|l|l|l|l|l|l|}
1 & 2 & 3 & 4 & 5 & 6 & $\mathrm{dst}$ \\
\hline
\end{tabular}

5. Tunalaras (Anak yang mengalami gangguan emosi dan perilaku)

a. Mudah teransang emosinya/emosional/mudah marah

b. Menetang otoritas

c. Sering melakukan tindakan agresif, merusak, mengganggu

d. Sering bertindak melanggar norma sosial/normasusial/hukum dan agama

\section{Anak berbakat/memiliki kemampuan dan kecerdasan luar biasa}

a. Membaca pada usia lebih muda

b. Membaca lebih cepat dan lebih banyak

c. Memiliki perbendaharaan kata yang luas

d. Mempunyai rasa ingin tahu yang kuat

e. Mempunyai minat yang luas, juga terhadap masalah orang dewasa

f. Mempunyai inisiatif dan dapat bekerja sendiri

g. Menunjukkan keslahan (orisinalitas) dalam ungkapan verbal

h. Memberi jawaban, jawaban yang baik

i. Dapat memberikan banyak gagasan

j. Luwes dalam berfikir

k. Terbuka terhadap rangsanganrangsangan dari lingkungan

l. Mempunyai pengamatan yang tajam

m. Dapat berkonsentrasi dalam jangka waktu yang panjang terutama dalam tugas atau bidang yang diminati

n. Berfikir kritis juga terhadap diri sendiri 


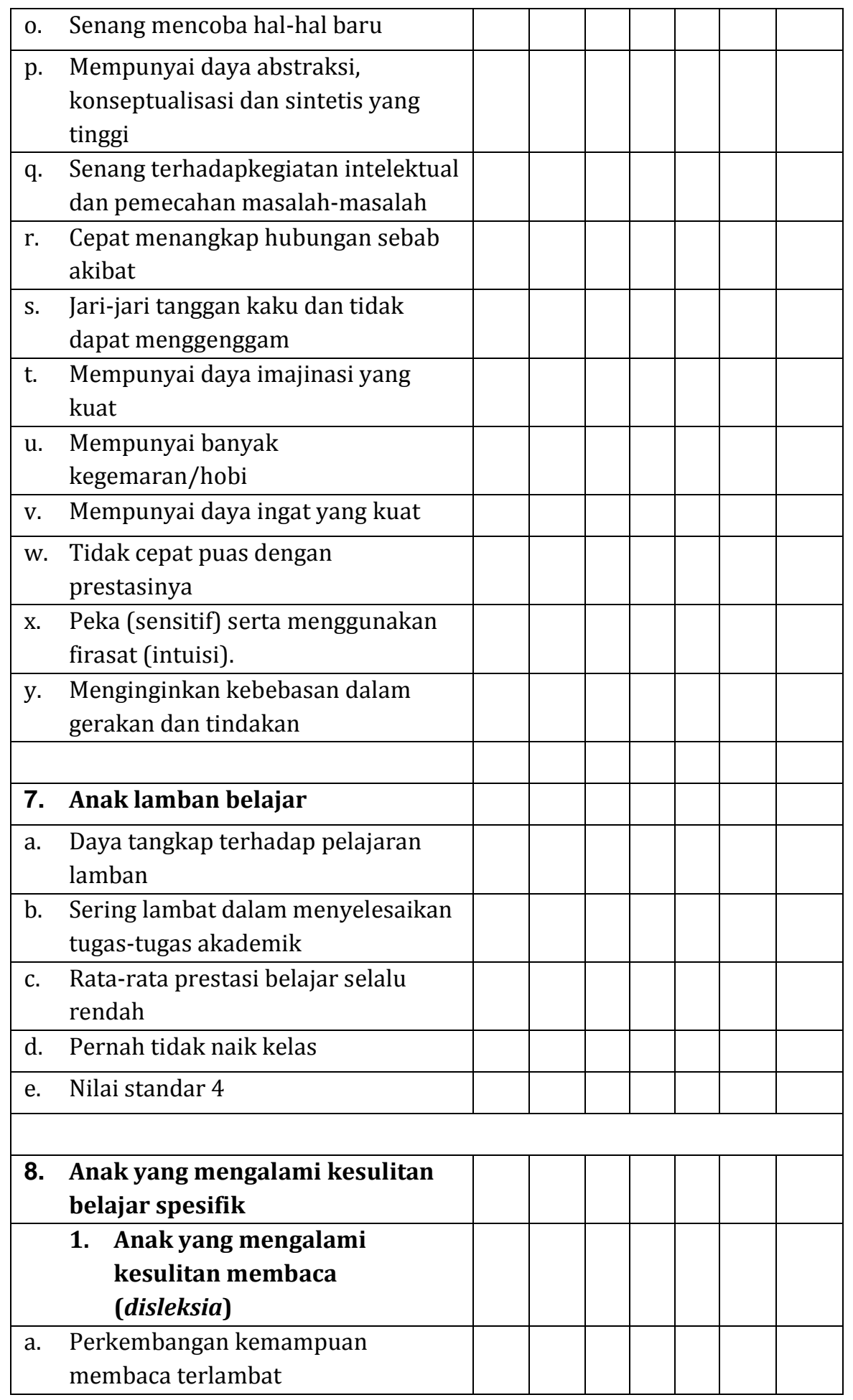




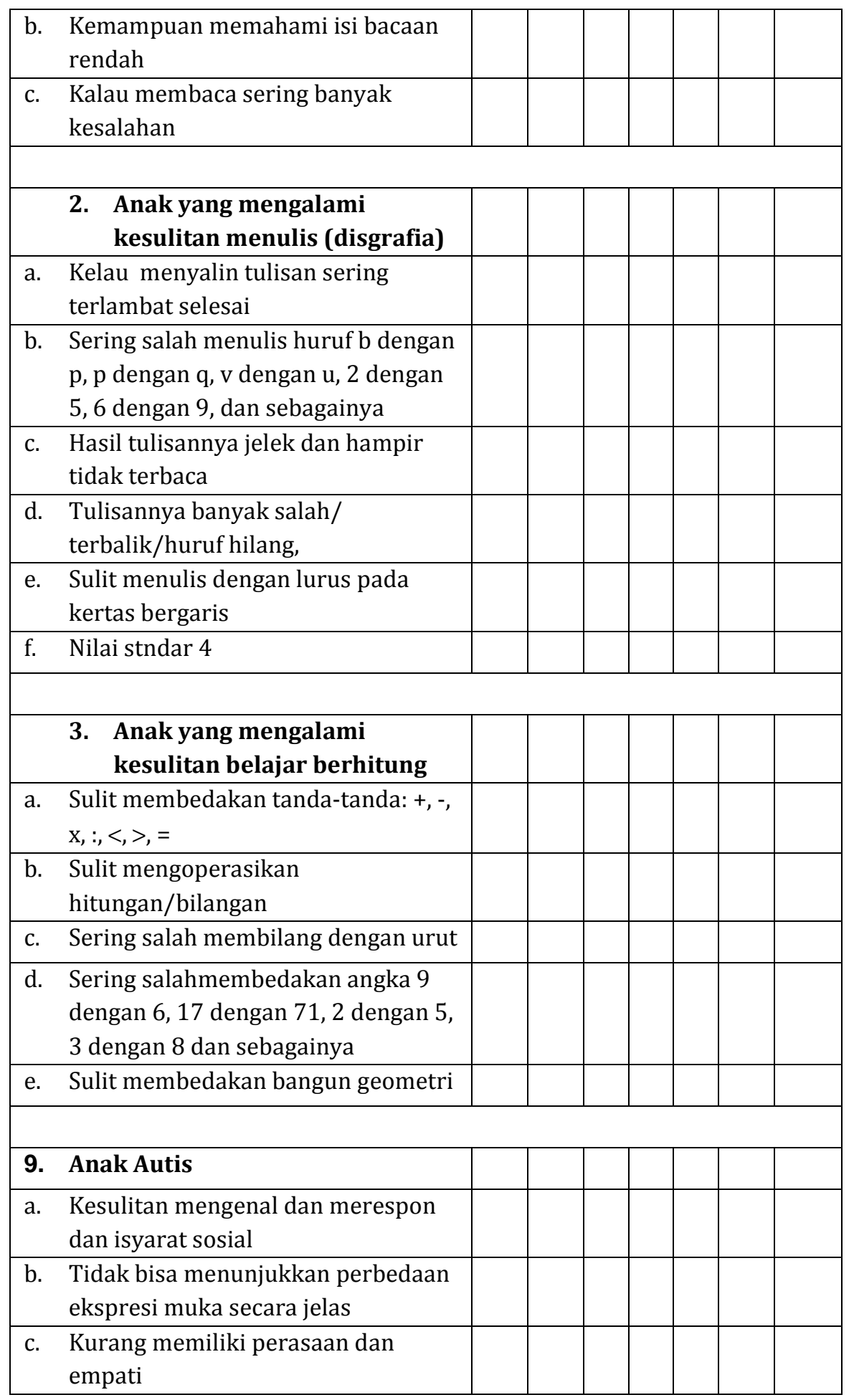




\begin{tabular}{|ll|l|l|l|l|l|l|l|}
\hline d. & Ekspresi emosi yang kaku & & & & & & & \\
\hline e. & $\begin{array}{l}\text { Sering menunjukkan perilaku dan } \\
\text { meledak-ledak }\end{array}$ & & & & & & & \\
\hline f. & $\begin{array}{l}\text { Menunjukkan perilaku yang bersifat } \\
\text { streotip }\end{array}$ & & & & & & & \\
\hline g. & $\begin{array}{l}\text { Sulit untuk diajak berkomunikasi } \\
\text { secara verbal }\end{array}$ & & & & & & & \\
\hline h. & Cenderung menyendiri & & & & & & & \\
\hline i. & $\begin{array}{l}\text { Sering mengabaikan situasi } \\
\text { disekelilingnya }\end{array}$ & & & & & & & \\
\hline
\end{tabular}

Kesimpulan:

Instrumen di atas diisi dengan ceklis berdarkan gejala yang dapat dilihat langsung dari setiap peserta didik berdasarkan nomor urut setiap peserta didik. Jika ditemukan anak berkebutuhan khusus, maka langkah selanjutnya melakukan asesmen.

\section{B. Asesmen Anak Berkebutuhan Khusus}

Tindak lanjut yang akan dilakukan setelah identifikasi selesai dilaksanakan, hendaknya dilanjutkan dengan kegiatan asesmen agar 
peserta didik yang diidentifikasi tergolong kedalam salah satu kategori anak berkebutuhan khusus dapat kita gali informasi yang lebih detail tentang anak tersebut.

Lerner (Budiyanto, 2013:55) mengemukakan bahwa asesmen adalah suatu proses pengumpulan informasi selengkap-lengkapnya mengenai individu yang akan digunakan untuk membuat pertimbangan dan keputusan yang berhubungan dengan individu tersebut. Begitu juga secara spesifik McLoughlin dan Lewis menjelaskan tentang asesmen pendidikan anak berkelainan adalah proses pengumpulan informasi yang relevan dengan kepentingan pendidikan anak, yang dilakukan secara sistematis dalam rangka pembuatan keputusan pengajaran atau layanan khusus.

Pengertian lain (Budiyanto, 2013:56) mengatakan bahwa asesmen ABK memiliki 10 macam kecendrungan;

1. Menilai anak berkebutuhana khusus secara individual

2. Menggunakan berbagai prosedur

3. Mengembangkan tes baru dan prosedur lain untuk mengasesmen kemampuan akademik, bahasa, dan keterampilan lain

4. Mengidentifikasi informasi lain yang relevan dengan pendidikan, sehingga tercapai tujuan instruksional dan pendidikan

5. Menilai lingkungan anak melalui beberapa pertanyaan dan tugas

6. Mengevaluasi secara berkelanjutan atau memonitor program

7. Mengembangkan prosedur asesmen non diskriminasi

8. Menggunakan pendekatan tim dalam asesmen

9. Mengembangkan peran guru pendidikan khusus dalam asesmen

10. Menggunakan data asesmen untuk membuat keputusan legal pembelajaran yang sesuai dengan kondisi anak.

Dapat disimpulkan bahwa asesmen adalah suatu bentuk penggalian informasi seorang anak baik tentang dirinya maupun lingkungan dengan menggunakan instrumen khusus agar dapat menjadi patokan pendidikan lebih lanjut.

Secara garis besar asesmen terbagi menjadi dua, yaitu (1) asesmen akademik (academic assesment), dan (2) asesmen perkembangan (developmental assesment). Asesmen Perkembangan merupakan suatu proses pengumpulan informasitentang aspek-aspek perkembangan anak yang diduga secara signifikan berpengaruh terhadap prestasi akademiknya yang diperlukan sebagai bahan pertimbangan dalam merencanakan program pembelajarannya.

Menurut Harwell (Budiyanto, 2013:59) aspek-aspek perkembangan anak yang perlu diasesmen diantaranya; (1) gangguan motorik, (2) 
gangguan persepsi, (3) gangguan atensi/perhatian, (4) gangguan memori, (5) hambatan dalam orientasi ruang, arah/spasial, (6) hambatan dalam perkembangan bahasa, (7) hambatan dalam pembentukan konsep, dan mengalami masalah dalam perilaku. Lebih lanjut mangungsong memberikan gambaran tentang tingkatan perkembangan belajar anak dan kaitannya dengan asesmen (Budiyanto, 2013:59-60) seperti matrik di bawah ini;

Tabel 4.2. Matrik Perkembangan Belajar

\begin{tabular}{|c|c|c|}
\hline $\begin{array}{c}\text { Tingkatan } \\
\text { Proses Belajar }\end{array}$ & Indikator Asesmen & Uraian \\
\hline \multirow[t]{5}{*}{$\begin{array}{l}\text { Tingkatan Motorik } \\
\text { (Doing Level) }\end{array}$} & Diferensiasi & $\begin{array}{l}\text { Kemampuan memilih dan } \\
\text { menggunakan secara } \\
\text { tersendiri bagian-bagian } \\
\text { tubuh dan menggerakkannya } \\
\text { secara terkontrol }\end{array}$ \\
\hline & Keseimbangan & $\begin{array}{l}\text { Kesadaran dan kemampuan } \\
\text { mempertahankan suatu } \\
\text { hubungan kearah titik pusat } \\
\text { dari gaya tarik bumi }\end{array}$ \\
\hline & $\begin{array}{l}\text { Hubungan } \\
\text { keruangan }\end{array}$ & $\begin{array}{l}\text { Kesadaran tubuh, lateralitas } \\
\text { (dua sisi bagian tubuh), arah } \\
\text { (kemampuan } \\
\text { memproyeksikan lateralitas } \\
\text { dalam ruangan }\end{array}$ \\
\hline & Ritme & $\begin{array}{l}\text { Jarak dan kombinasi dari } \\
\text { berbagai interval waktu }\end{array}$ \\
\hline & Mata-tangan & $\begin{array}{l}\text { Kemampuan menggabungkan } \\
\text { apa yang dilihat dengan } \\
\text { gerakan motorik halus }\end{array}$ \\
\hline \multirow[t]{4}{*}{$\begin{array}{l}\text { Tingkatan } \\
\text { Persepsi } \\
\text { (Matching Level) }\end{array}$} & Diskriminasi & $\begin{array}{l}\text { Kemampuan membedakan } \\
\text { suatu bentuk (persepsi) dari } \\
\text { bentuk yang lain }\end{array}$ \\
\hline & Bentuk dan latar & $\begin{array}{l}\text { Kemampuan membedakan } \\
\text { suatu bentuk utama dari } \\
\text { latarnya (mana stimulus inti } \\
\text { dan mana stimulus latarnya) }\end{array}$ \\
\hline & Closure & $\begin{array}{l}\text { Kemampuan untuk } \\
\text { menambahkan detail yang } \\
\text { hilang dari suatu } \\
\text { bentuk/benda }\end{array}$ \\
\hline & Ingatan & Kemampaun untuk mengingat \\
\hline
\end{tabular}




\begin{tabular}{|l|l|l|}
\hline & & $\begin{array}{l}\text { kembali apa yang pernah } \\
\text { diperoleh melalui indera }\end{array}$ \\
\hline & Sekuens & $\begin{array}{l}\text { Kemampuan untuk mengatur } \\
\text { secara tepat sesuai dengan } \\
\text { urutan, sesuatuyang pernah } \\
\text { diamati melalui indera }\end{array}$ \\
\hline & Integrasi & $\begin{array}{l}\text { Penggunaan dari dua saluran } \\
\text { input atau lebih, secara } \\
\text { serentak dan kemampuan } \\
\text { untuk menghubungkan } \\
\text { keduanya }\end{array}$ \\
\hline Tingkatan & & $\begin{array}{l}\text { Kemampuan membuat } \\
\text { kategori, dan klasifikasi } \\
\text { Konseptual } \\
\text { (Categorization }\end{array}$ \\
Level) & & $\begin{array}{l}\text { pengalaman-pengalaman yang } \\
\text { diperoleh }\end{array}$ \\
\hline
\end{tabular}

Sementara Asesmen akademik (academic assesment). Asesmen akademik merupakan suatu proses yang dilakukan untuk mengumpulkan data atau informasi yang berkenaan dengan prestasi belajar yang telah dicapai anak. Asesmen akademik sekurang-kurangnya mencakup kemampuan dasar, yaitu asesmen keterampilan membaca, asesmen keterampilan menulis, dan asesmen keterampilan berhitung. (Budiyanto, 2013:61-63)

Tabel 4.3. Ceklis Pengamatan Membaca

Nama siswa :

Kelas

Sekolah

Nama Guru

\begin{tabular}{|c|c|c|c|c|c|}
\hline \multirow{2}{*}{ No } & \multirow{2}{*}{ Perilaku Membaca } & \multicolumn{4}{|c|}{ Pengamatan ke } \\
\hline & & 1 & 2 & 3 & 4 \\
\hline \multicolumn{6}{|c|}{ Jenis kesalahan membaca teknis } \\
\hline 1 & Membaca dengan mengeja & & & & \\
\hline 2 & Pengucapan yang tidak benar & & & & \\
\hline 3 & Menerka-nerka kata & & & & \\
\hline 4 & Pemenggalan tidak tepat & & & & \\
\hline 5 & Penghilangan bunyi/kata & & & & \\
\hline 6 & Mengulang-ngulang & & & & \\
\hline 7 & Terbalik & & & & \\
\hline 8 & Menambahkan unsur bunyi & & & & \\
\hline
\end{tabular}




\begin{tabular}{|c|l|l|l|l|l|}
\hline 9 & Mengamati dengan bunyi lain & & & & \\
\hline 10 & Tidak mengenal kosa kata pandang & & & & \\
\hline 11 & Tidak mengenal bunyi konsonan & & & & \\
\hline 12 & Tidak mengenal bunyi vocal & & & & \\
\hline 13 & Tidak mengenal konsonan/vocal ganda & & & & \\
\hline 14 & Kemampuan analisis struktur lemah & & & & \\
\hline 15 & Tidak mampu memanfaatkan konteks & & & & \\
\hline Kesalahan Membaca Pemahaman & & & & \\
\hline 16 & Tingkat pemahaman rendah & & & & \\
\hline 17 & Penguasaan memanfaatkan konteks & & & & \\
\hline 18 & Kurang mampu mengingat isi bacaan & & & & \\
\hline 19 & Jawaban tidak terstruktur secara baik & & & & \\
\hline 20 & Tidak mampu mencari informasi tertentu & & & & \\
\hline 21 & Tidak mampu membaca sepintas & & & & \\
\hline 22 & Banyak salah ejaan pada jawaban & & & & \\
\hline Jenis Kesalahan Umum & & & & \\
\hline 23 & Lambat dalam membaca & & & & \\
\hline 24 & Membaca cepat, tetapi banyak salah & & & & \\
\hline 25 & Membaca sambil berbisik & & & & \\
\hline 26 & Tidak menguasai abjad & & & & \\
\hline
\end{tabular}

Dalam melakukan penilaian ini tim penilai yang telah dibentuk melakukan observasi untuk mengetahui kemampuan anak dari segi membaca. Anak disuruh membaca sebuah teks kemudian diberikan bebarapa pertanyaan yang berkenaan dengan kemampuan baca anak berkebutuhan khusus tersebut.

Setelah melakukan observasi kemampuan membaca, langkah yang dilakukan selanjutnya dengan mengisi form observasi kebiasaan menulis (Budiyanto, 2013:62) di bawah ini;

Tabel 4.4 Formulir Kebiasaan Menulis

Nama siswa :

Kelas

Sekolah

Nama Guru

\begin{tabular}{|c|l|c|c|c|}
\hline No & \multicolumn{1}{|c|}{ Perilaku membaca } & Ya & $\begin{array}{c}\text { Kadang } \\
- \\
\text { kadang }\end{array}$ & Tidak \\
\hline 1 & $\begin{array}{l}\text { Apakah anak memegang pensil dengan } \\
\text { benar? }\end{array}$ & & \\
\hline 2 & Apakah posisi kertas/ buku sudah benar? & & & \\
\hline
\end{tabular}




\begin{tabular}{|c|l|l|l|l|}
\hline 3 & $\begin{array}{l}\text { Apakah posisi duduk anak sudah benar } \\
\text { termasuk jarak antara mata dengan kertas }\end{array}$ & & & \\
\hline 4 & $\begin{array}{l}\text { Apakah anak tampak tegang, frustasi atau } \\
\text { emosional pada waktu menulis }\end{array}$ & & & \\
\hline 5 & $\begin{array}{l}\text { Apakah anak menunjukkan sikap negatif, } \\
\text { bosan, atau terganggu pada waktu menulis }\end{array}$ & & & \\
\hline
\end{tabular}

Dari observasi yang dilakukan seperti yang terdapat dalam tabel diatas maka observer akan menemukan beberapa gejala seperti di atas, agar dapat menjadi pertimbangan dalam pembelajarannya.

Kemudian terkait dalam bidang agama Islam dapat dilakukan asesmen terhadap anak berkebutuhan khusus sesuai dengan tingkatannya. Berikut merupakan contoh soal yang dapat diajukan sebagai berikut;

Soal Pendidikan Agama Islam (Disesuaikan dengan ABK) (untuk kelas dua)

Nama siswa :

Kelas

Sekolah

1. Siapa tuhan kita?

2. Bolehkah kita bohong ?

3. Bolehkah kita durhaka sama orang tua?

4. Orang jahat akan masuk?

5. Anak shaleh akan disayang?

Selain melakukan pengamatan langsung kepada anak berkebutuhan khusus, keterangan dari orang tua sangat berguna dalam mengumpulkan informasi tentang tumbuh kembang anak semenjak dalam kandungan hingga sekolah (Budiyanto, 2013:70) sebagai berikut;

\section{Formulir 4.1 Informasi Perkembangan Anak}

(Diisi oleh orang tua)

\section{Petunjuk:}

Isilah daftar pada kolom yang tersedia sesuai dengan kondisi anak yang sebenarnya. Jika ada yang kurang jelas, konsultasikan kepada guru kelas tempat anak bapak/ibu bersekolah.

a. Identitas Anak

1. Nama

2. Tempat dan tanggal lahir

3. Jenis kelamin 

4. Agama
5. Status anak
6. Anak ke dari jumlah bersaudara
7. Nama sekolah
8. Kelas
9. Alamat

\section{b. Riwayat Kelahiran}

1. Perkembangan masa kehamilan

2. Penyakit pada masa kehamilan

3. Usia kandungan

4. Tempat proses kelahiran

5. Tempat kelahiran

6. Penolong proses kelahiran

7. Gangguan pada saat bayi lahir

8. Berat bayi

9. Panjang bayi

10. Tanda-tanda kelainan pada bayi

\section{c. Perkembangan Masa Balita}
1. Minum ASI hingga umur
2. Minum susu kaleng hingga umur
3. Imunisasi (lengkap/tidak)
4. Melakukan penimbangan rutin/tdk :
5. Kualitas makanan
6. Kualitas makan
7. Kesulitan makan (ya/tdk)

\section{d. Perkembangan Fisik}
1. Dapat berdiri pada umur
2. Dapat berjalan pada umur
3. Naik sepeda roda tiga pada umur
4. Naik sepeda roda dua pada umur
5. Bicara dengan kalimat lengkap
6. Kesulitan gerakan dialami
7. Status gizi balita (baik/kurang)
8. Riwayat kesehatan (baik/kurang)
9. Penggunaan tangan dominan

\section{e. Perkembangan Bahasa}

1. Meraba/ berceloteh pada umur

2. Mengucapkan satu suku kata yang bermakna (mis.Pa berarti bapak) pada umur

3. Berbicara dengan satu kata bermakna pada umur :

4. Berbicara dengan kalimat lengkap sederhana pada umur : 
f. Perkembangan Sosial

1. Hubungan dengan saudara

2. Hubungan dengan teman

3. Hubungan dengan orang tua

4. Hobi

5. Minat khusus

g. Perekembangan Pendidikan

1. Masuk TK umur

2. Lama pendidikan

3. Kesulitan selama di TK

4. Masuk SD umur

5. Kesulitan selama SD

6. Pernah tidak naik kelas

7. Pelayanan khusus yang pernah diterima

8. Prestasi belajar yang dicapai

9. Mata pelajaran yang dirasa paling sulit

10. Mata pelajaran yang dirasa paling disenangi :

11. Keterangan lain yang dianggap perlu :

Diisi tanggal,

Orang Tua,

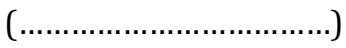

Formulir 4.2 Data Orang Tua/Wali Siswa

(Diisi orang tua/wali siswa)

1. Nama

2. $\mathrm{SD} / \mathrm{MI}$

3. Kelas

\section{A. Identitas Orang tau / wali}

Ayah

1. Nama Ayah

2. Umur

3. Agama

4. Pendidikan Tertinggi

5. Pekerjaan Pokok

6. Alamat tinggal 


\section{Ibu}

1. Nama Ibu

2. Umur

3. Agama

4. Pendidikan Tertinggi

5. Pekerjaan Pokok Alamat tinggal

\section{Wali}

1. Nama

2. Umur

3. Agama

4. Status perkawinan

5. Pendidikan Tertinggi

6. Pekerjaan

7. Alamat

8. Hubungan keluarga

B. Hubungan Orang tua-anak

1. Kedua orang tua satu rumah

2. Anak satu rumah dengan kedua orang tua :

3. Anak diasuh oleh satu orang tua

4. Anak diasuh wali/saudara

\section{Sosial Ekonomi Orang tua}

1. Jabatan formal ayah di kantor (jika ada)

2. Jabatan formal ibu di kantor (jika ada)

3. Jabatan informal ayah di luar kantor (jika ada)

4. Jabatan informal ibu di luar kantor (jika ada)

5. Rata-rata pengahasilan (kedua orang tua) perbulan

D. Tanggungan dan tanggapan Keluarga

1. Jumlah Anak

2. Ybs. Anak yang ke

3. Persepsi orang tua terhadap anak ybs

4. Kesulitan orang tua terhadap anak ybs

5. Harapan orang tua terhadappendidikan anak ybs

6. Bantuan yang diharapkan orang tua untuk anak ybs

Diisi tanggal,

Orang Tua,

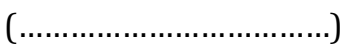


Formulir 4.3 Daftar Anak Yang Terindikasi Berkelainan Dan Memerlukan Pelayanan Khusus

1. $\mathrm{SD} / \mathrm{MI}$

2. Kelas

3. Nama Guru

\begin{tabular}{|c|c|c|c|c|}
\hline No & Nama & $\mathbf{L} / \mathbf{P}$ & Uraian & Keterangan \\
\hline 1 & Amin & $\mathrm{L}$ & 1. Kesulitan belajar Matematika & Standar \\
\hline & & & $\begin{array}{l}\text { 2. Gangguan Penglihatan } \\
\text { 3. Sering tidak masuk karena sakit }\end{array}$ & $\begin{array}{l}\text { nilai yang } \\
\text { dicapai }=4\end{array}$ \\
\hline 2 & Nisa & $\mathrm{P}$ & $\begin{array}{l}\text { 1. Kesulitan hampir semua mata } \\
\text { pelajaran (lamban belaiar) }\end{array}$ & $\begin{array}{l}\text { Jumlah } \\
\text { Saudara }\end{array}$ \\
\hline 3 & Dst & & $\begin{array}{l}\text { 2. Keluarga miskin, penghasilan rata- } \\
\text { rata Perbulan (Rp. 300.000, } \\
\text { dengan jumlah tanggungan } \\
\text { keluarga } 8 \text { orang. }\end{array}$ & $\begin{array}{l}\text { yang } \\
\text { sekolah } 5 \\
\text { orang } \\
\text { dst }\end{array}$ \\
\hline & & & & \\
\hline
\end{tabular}

Dibuat tanggal,

Guru Kelas,

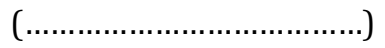

Setelah melakukan asesmen, maka tindakan lanjutan ialah dengan menganalisa hasil asesmen tehadap anak berkebutuhan khusus, dimana berguna untuk menyusun program pengajaran individual. Selain itu ada beberapa fungsi dari hasil asesmen (Budiyanto, 2013:20-21) seorang anak berkebutuhan khusus, seperti;

1. Sebagai dasar perencanaan pembelajaran individual

Data hasil asesmen yang mengambarkan potensi, karakteristik, keunggulan dan kelemahan peserta didik, selanjutnya dipergunakan sebagai pertimbangan utama dalam penentuan program pembelajaran (perencanaan pembelajaran) secara individual peserta didik. Dalam konteks yang lebih luas, penentuan kurikulum bagi peserta didik berkebutuhan khusus selalu didasarkan hasil asesmen yang telah dilakukan. Begitu pula dengan perumusan kurikulum modifikasi, indikator utama modifikasi kurikulum juga didasarkan pada hasil asesmen. 
2. Sebagai dasar evaluasi dan monitoring

Standar kegiatan evaluasi dan monitoring bagi peserta didik berkebutuhan khusus didsarkan pada base line yang ditetapkan dari hasil asesmen. Lebih lanjut penentuan perolehan hasil belajar ditentukan dari peningkatan kemampuan atau tingkat perubahan dari base line yang telah ditetapkan sebelumnya.

3. Sebagai dasar pengalihtanganan (Referal)

Pertimbangan pengalihtanganan penanganan kasus sesuai hasil asesmen mengacu keahlian (profesionalitas) yang kompeten. Contoh; seorang guru (pedgog) menemukan peserta didiknya tersebut kepada psikiater. Dalam konteks pendidikan inklusif penanganan lintas profesi menjadi keharusan, karena keragaman karakteristik peserta didik menuntut layanan lintas profesi yang profesional.

McLoughlin (Budiyanto, 2013:65) memberikan visual kegiatan identifikasi dan asesmen dengan skema sebagai berikut;

Gambar 4.1 Skema PPI

Proses Penyusunan Program Pengajaran Individual

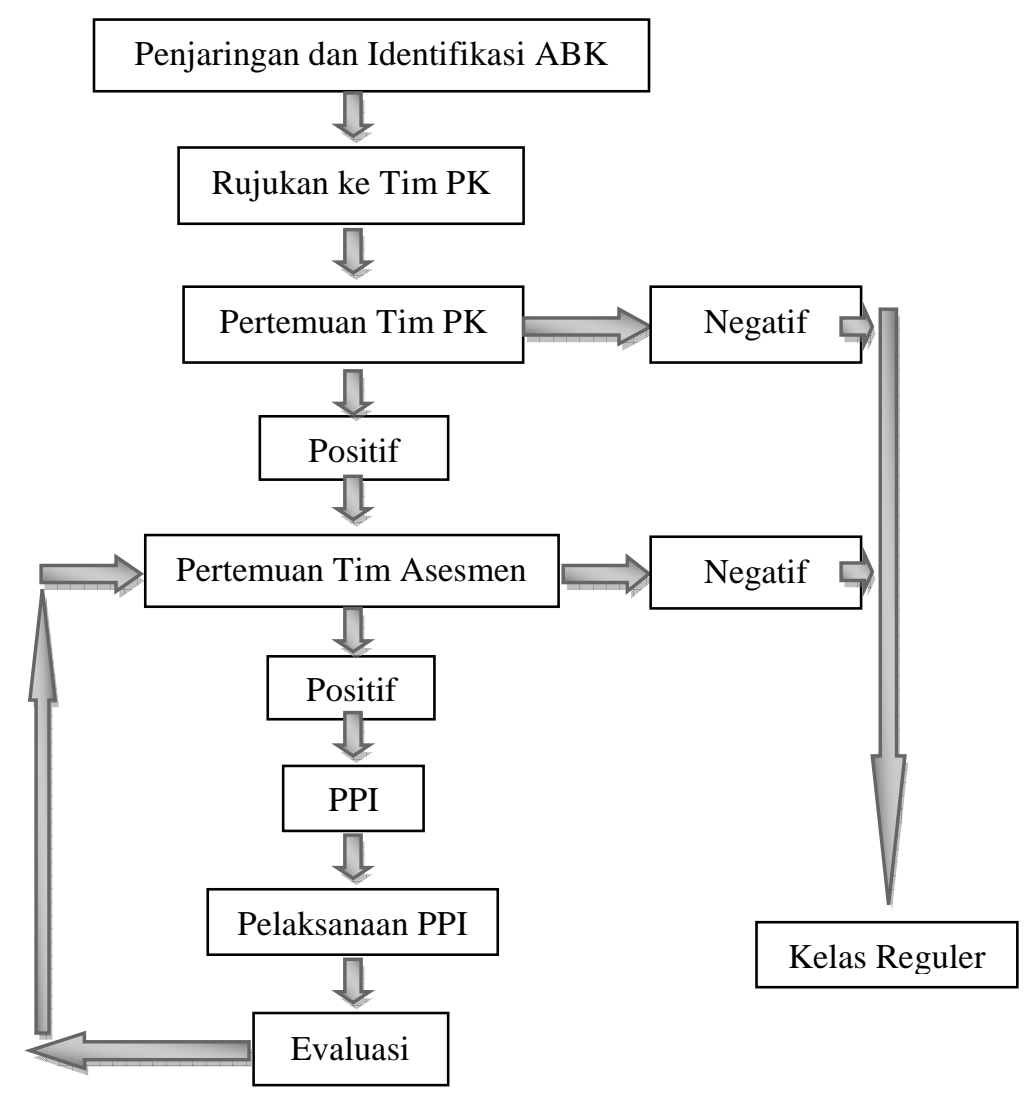


Dalam melakukan identifikasi dan asesmen, ada beberapa hal (Direktorat PKLK, 2013:21-22) yang harus diperhatikan, diantaranya;

a. Satuan pendidikan penyelenggara pendidikan inklusif harus melakukan identifikasi dan asesmen terhadap semua peserta didiknya

b. Identifikasi dan asesmen harus dilakukan oleh tim yang dibentuk oleh satuan pendidikan

c. Tim identifikasi dan asesmen satuan pendidikan sebaiknya melibatkan semua komponen sekolah dan sedapat mungkin dapat didukukung oleh tenaga profesional lainnya sesuai dengan kondisi sekolah

d. Komponen sekolah yang dimaksud pada butir (c) adalah kepala sekolah, guru kelas, guru BK, dan guru khusus

e. Tenaga profesional lainnya yang dimaksud butir (c) adalah dokter, psikiater, psikolog, pekerja sosial, dan terapi

f. Satuan pendidikan penyelenggara pendidikan inklusif dapat bekerja sama dan membangun jaringan dengan satuan pendidikan khusus, perguruan tinggi, organisasi profesi, lembaga rehabilitasi, rumah sakit, pusat kesehatng disediakanan masyarakat, klinik terapi, dunia usaha, lembaga swadaya masyarakat, dan masayarakat.

g. Dalam identifikasi, tim dapat menggunakan pedoman identifikasi yang disediakan

h. Screening dan klasifikasi dilakukan dengan menggunakan alat tes yang terstandarisasi (standardized). Contoh; seorang peserta didik yang dinyatakan autis dalam tingkatan tertentu dengan menggunakan instrumen CARS (Childhood Autism rating Scale). Yang berwenang melakukan screening dan klasifikasi adalah tenaga profesional. Guru menggunakan hasil tes tersebut untuk merancang kegiatan pembelajaran.

i. Asesmen akademik dilaksanakan oleh guru untuk menilai kemampuan dan ketidak mampuan akademis peserta didik pada awal program. Guru dapat menggunakan alat/media buatan sendiri

j. Asesmen non akademik dilakukan oleh ahlinya sesuai dengan kebutuhan pada suatu saat guru memerlukan informasi (mis. Gangguan gerak dilakukan rehab medik atau fisioterapi)

k. Hasil identifikasi dan asesmen harus digunakan sebagai acuan dalam penyusunan dan pengembangan kurikulum, pembelajaran, penyediaan sarana dan prasarana, sumber daya manusia, penilaian dan pembiayaan sekolah. 


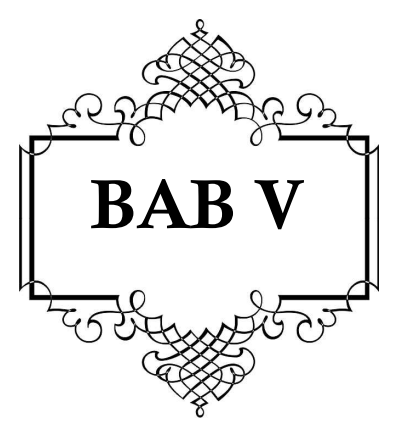

\section{LAYANAN PENDIDIKAN ANAK BERKEBUTUHAN KHUSUS}

Setelah membaca bab ini pembaca diharapkan:

* Memahami cara mendidik siswa yang mengalami intelektual di bawah rata-rata

* Memahami cara mendidik siswa yang mengalami gangguan perilaku

+ Memahami cara mendidik siswa yang mengalami Autisme

\section{A. Intelektual di bawah rata-rata}

Anak dengan intelektual dibawah rata-rata (retardasi mental) atau disebut juga dengan tunagarhita adalah anak yang secara nyata mengalami hambatan dan keterbelakangan perkembangan mental intelektual jauh di bawah rata-rata sedemikian rupa sehingga mengalami kesulitan dalam tugas-tugas akademik, komunikasi maupun sosial, dan karenanya memerlukan layanan pendidikan kebutuhan khusus (Ganda Sumekar, 2009:123).

Anak-anak yang mengalami lamban belajar memiliki ciri-ciri (Budiyanto, 2013:42) sebagai berikut:

1) Daya tangkap terhadap pelajaran lambat

2) Sering lambat dalam menyelesaikan tugas-tugas akademik

3) Rata-rata prestasi belajar selalu rendah, dan

4) Pernah tidak naik kelas. 
Untuk memberikan layanan bagi siswa yang mengalami gangguan in intelektual maka ada beberapa hal yang harus diperlukan, diantaranya:

a) Guru yang efektif bagi siswa bergangguan intelektual

Dalam prinsip guru yang efektif ini Wong, Kauffman dan Lloyd yang dikutip Ganda Sumekar, 2009:162) disebutkan ciri-cirinya antara lain:

1) Punya harapan bahwa siswa akan berhasil

2) Memberi pengawasan yang sering pada tugas-tugas sekolah siswa serta member umpan balik

3) Memberikan penjelasan standar-standar, arah-arah, dan harapan-harapan pembelajaran

4) Fleksibel dalam menangani siswa

5) Mempunyai komitmen dalam memperlakukan tiap siswa

6) Bersikap responsif terhadap pertanyaan dan komentar siswa

7) Melakukan pendekatan tersusun dengan baik dalam pengajaran

8) Bersikap hangat, sabar, humoris kepada siswa

9) Bersifat teguh dan konsisten dalam pengaharapan-pengaharapan

10) Mempunyai pendekatan-pendekatan pengaturan berbagai sikap

11) Bersikap terbuka dan positif terhadap perbedaan dan kelainan anak-anak dan orang dewasa

12) Mempunyai kemauan kerjasama dengan gurupendidikan khusus dan bersikap responsive dalam membantu orang lain

13) Mempunyai rasa percaya diri dan kompetensi sebagai seorang guru

14) Punya rasa keterlibatan professional yang tinggi serta pemuasan professional

b) Menajemen dan disiplin kelas

1) Guru dan siswa menggunakan waktu secara efisien

2) Siswa-siswa tidak menunggu untuk meminta bantuan

3) Siswa-siswa hanaya mengggunakan sedikit waktu dalam melakukan perpindahan dari satu aktifitas ke aktivitas lainnya

4) Tidak banyak yang diperlukan untuk menegakkan disiplin

5) Guru jarang melakukan hukuman

6) Penaganan-penaganan khusus lainnya tidak diperlukan dalam mengatur sikap 
c) Umpan balik selama pembelajaran

1) Guru memberikan umpan balik positif bagi siswa untuk mendapatkan sikap dan prestasi yang layak

2) Guru membantu siswa menemukan jawaban yang benar bila jawabannnya salah

3) Guru mengindari umpan balik yang negatif kepada siswa, serta menghindari kritik kepada siswa dan tugas mereka

d) Pengembangan pembelajaran yang tepat

1) Guru memberikan tugas-tugas pada tingkat kesulitan yang layak bagi setiap siswa

2) Siswa dapat melakukan setiap tugas dengan sedikit kesalahan

3) Siswa dapat diberikan nilai tinggi terhadap jawaban yang benar dari tugas dan pertanyaan guru

4) Guru dan murid berinteraksi sangat positif yang berhubungan dengan tugas pengajaran

e) Suasana pembelajaran yang kondusif

5) Guru melakukan penangan yang mendukung ketimbang menuduh

6) Guru merespon dengan perhatian dan pemahaman kepada siswa yang mempunyai tingkat kemampuan lebih rendah

7) Guru lebih mendukung bila siswa mempunyai suatu masalaha pembelajaran

8) Siswa percaya pada guru dan mau meminta bantuan

9) Rasa percaya diri siswa terhadap kemampuan dalam belajar meningkat

10) Tingkat dan kualiatas proses pembelajaran siswa menjadi kokoh. (Ganda Sumekar, 2009:165-167)

\section{B. Gangguan Prilaku}

Gangguan-gangguan perhatian dan hyper aktivitas diberi kategori tunggal, yaitu attention deficit/ hyperactivitiy disorders (ADHD) oleh American Psyciatric Association dalam diagnostic and Statistical Manual of Mental Disorders. Diagnostic and statistical manual of mental disorders tersebut tidak membedakan antara keduanya dikarenakan kurang bukti bahwa hyperactivity dan attention deficits merupakan kategori perilaku yang berbeda. (Ganda Sumekar, 2009:238-230)

Berikut beberapa layanan yang dapat diberikan kepada anak yang mengalami gangguan perilaku:

1. Mengatasi masalah emosi dan prilaku 
Ganda sumekar ( 2009:223) mengutif pendapat Sabatino tentang berapa cara dianjurkan dalam menciptakan susana kelas yang dapat meningkatkan sikap-sikap positif dan membantu mencegah sikap-sikap negatif:

a) Buatlah harapan-harapan akademis dan prilaku siswa yang anda inginkan sejelas mungkin bagi mereka

b) Tunjukkan pada siswa bahwa anda jujur dalam berhubungan dengan mereka

c) Berikan perhatian dan pengakuan pada siswa atas sifat-sifat dan prestasi yang positif. Suatu aturan yang baik adalah menemukan suatu yang positif untuk dinyatakan kepada siswa setiap hari

d) Buatlah contoh sikap, kebiasaan kerja, dan hubungan yang positif

e) Persiapan pola pengajaran dan berikan kurikulum yang tersusun dengan baik

f) Buatlah Susana kelas yang dapat diterima, baik secara fisik maupun sosial.

\section{Keterampilan menajemen diri (self-menagement skill)}

Menurut Alberto dan Troutman seperti yang dikutip Ganda sumekar menyatakan beberapa cara menajemen diri dapat dicoba kepada siswasiswa dikelas-kelas inklusif, adalah:

a) Pemantauan diri (self-monitoring)

Teknik pemantauan diri (self-monitoring) telah dipakai dalam berbagai cara-cara yang strategis dalam mengubah dan menyusun sikapsikap di kelas. Termasuk mengubah pola pengajaran siswa agar sadar dan mencatat seberapa sering mereka tidak masuk kelas, jumlah waktu mereka bercakap-cakap diluar kelas, jumlah waktu mereka melakukan tindakan agresif terhadap orang lain, dan jumlah waktu mreka melakukan tugastugas akademis.

b) Intervensi diri (self-inrevention)

Setelah mereka sadar akan sikap diri mereka sendiri dan dampaknya terhadap orang lain, mungkin penting mengajari mereka cara memberikan penghargaan diri mereka sendiri secara sistematis bagi perubahan dalam sikap tersebut, seperti pemberian bintang emas, sertifikasi prestasi yang diperlihatkan kepada orang tua mereka

c) Pengarahan diri (self-instruction)

Menurut J. David Smith yang dikutip oleh Ganda Sumekar, ada beberapa latihan-latihan dalam mengajarkan mereka menganalisis 
masalah serta mengembangkan solusi yang tepat bagi masalah-masalah tersebut, meliputi:

- Mengenali masalah (apa yang telah diminta untuk saya kerjakan?)

- Menciptakan solusi yang mungkin (cara apa yang dapat saya lakukan)

- Analisis solusi-solusi yang mungkin (solusi apa yang nampaknya sangat tepat bagi sesuatu yang telah diminta untuk dilakukan?)

- Berusaha memecahkan masalah (bagaimana memilih suatu solusi yang dapat dilakukan?

- Nilailah apakah solusi itu berhasil (apakah ini membantu untuk menyelesaikan tugas secara berhasil?)

3. Penerapan analisis prilaku

Dalam beberapa kasus, sikap-sikap tidak pantas siswa yang mengalami gangguan emosi dan perilaku mungkin membutuhkan penanganan konsultan pendidikan khusus, yang dapat membantu gru kelas dalam menganalisis sifat dasar sikap-sikap tersebut, serta member bantuan dalam mengembangkan strategi-strategi penanganan. Berikut beberapa kemungkinan pertanyaan yang akan diajukan:

a) Seberapa seringkah perilaku itu terjadi ? kapan berakhirnya ketika itu terjadi? Seberapa beda perilaku ini dalam frekwensi dan durasi disbanding anak lain dikelas? Apa yang mengakibatkan munculnya perilaku ini? Adakah factor-faktor yang membuat perilaku ini semakin intensif? Adakah factor-faktor yang menguranginya?

b) Bagaimana asal-mulanya masalah ini? Sudah berapa lama siswa mempunyai perilaku ini? Berkembangkah perilaku itu kini? Apakah itu muncul atau menjadi besar sekarang ini dikarenakan perubahan kondisi siswa? Apakah sikap ini berhubungan berhubungan dengan mata pelajaran atau aktifitas tertentu di sekolah? Apakah itu muncul berhubungan dengan kecemasan tertentu atau pola-pola kegagalan akademis?

c) Sebagian hasil pertanyaan-pertanyaan ini, suatu gambaran mungkin muncul bagi masalah-masalah dan pola-pola yang perlu dibicarakan untuk memudahkan kelas berfungsi secara layak dan berhasil. Suatu rencana penganan dapat dibuat yang memuat pengawasan konsekwensi-konsekwensi dari sikap tersebut yang sudah diketahui sebagai masalah. Pilihan penguatan-penguatan yang positif dalam dalam meningkatkan sikap-sikap yang diinginkan atau solusi-solusi untuk mencegah menguatnya sikapsikap yang tidak diinginkan berdasarkan atas analisis ini. 
4. Latihan ketrampilan sosial (skillsteaming)

Berikut beberapa program-program ini meliputi unsure-unsur:

a) Peniruan/ modeling

b) Bermain peran/ role playing

c) Umpan balik untu kerja/ performance feedback

d) Mengalihkan keterampilan latihan/ transfer of training

5. Partisipasi keluarga

Menurut Welkowitz seperti yang dikutip Ganda Sumekar, Para orang tua melaporkan bahwa, dengan bertambahnya tingkat komunikasi dan berbagai informasi, proses kerja tim ini dapat ditindak lanjuti di rumah pada program pendidikan anak. Proses kerja tim ini dapat ditindaklanjuti di rumah pada program pendidikan anak. Proses kerja tim ini juga memungkinkan guru belajar dari orang tua.

\section{Latihan prilaku kognisi (cognitive behavioral training)}

Latihan perilaku kognisi ini merupakan suatu kumpulam cara-cara perubahan sikap dan strategi pengajaran lainnya. Cara ini menitik beratkan pada penggunaan mediasi verbal dalam meningkatkan sikap-sikap. Berikut ini suatu contoh latihan perilaku kognisi sebagaimana yang dikutip Ganda Sumekar pendapat J. David Smith, antara lain:

Langkah 1 : berhentilah dan fikirkan sebelum bertindak, tahan keinginan bertindak tanpa berfikir

Langkah 2 : katakana pada diri sendiri bagaimana persaan anda dan apa masalah bagi anda, tentukan masalahnya

Langkah 3 : pikirkan solusi masalah sebanyak mungkin, perhatikan alternative-alternatif terhadap cara anda bertindak lanjut sebelumnya

Langkah 4 : pikirkan lagi terhadap kemungkinan jika anda menggunakan alternatif, perhatikan konsekuensi yang mungkin bagi sikap anda

Langkah 5 : ketika anda mendapatkan alternatif yang terbaik, cobalah, bertindaklah. (Ganda Sumekar, 2009:228)

7. Kolaborasi teman sebaya (peer collaboration)

Bentuk kerjasama teman sebaya lain yang dapat berguna bagi siswa di kelas Inklusif adalah perantara teman sebaya (peer mediation). Teknik ini menyangkut latihan siswa dalam menengahi perbedaan-perbedaan di antara teman-teman mereka. Penegangah dilakukan saat latihan dalam teknik-teknik resolusi konflik 


\section{Sikap guru}

Sesuatu yang penting dalam keberhasilan inklusi siswa penyandang hambatan emosi dan perilaku di kelas-kelas regular adalah sikap-sikap guru yang mengatur kelas-kelas itu.

Menurut J. David Smith yang dikutip Ganda Sumekar, menuturkan beberapa sikap yang telah diidentifikasi yaitu: (Ganda Sumekar, 2009:229)

a) Fleksibel dalam harapan-harapan akademis, mengetahui bahwa siswa belajar berbeda-beda, pada tingkat-tingkat berbeda pula.

b) Fleksibel dalam harapan-harapan perilaku, berkeinginan untuk menangani siswa kearah kemampuan sikap dan sosial yang meningkat

c) Sikap humor, mampu memperlihatkan sikap humornya di kelas dan biasa tertawa bersama dengan siswa oleh humor-humor tersebut. (Ganda Sumekar, 2009:223-230)

\section{Autisme}

Istilah Autisme berasal dari kata autos (bahasa Yunani) yang berarti self atau 'diri sendiri'. Jadi penyandang autism pada dasarnya seseorang yang cenderung menikmati kegiatan dengan dirinya sendiri. (Kak Kresno, 2011:13)

Beberapa perilaku dibawah merupakan ciri khas dari anak-anak autis:

1) Kesulitan dengan komunikasi verbal maupun non verbal

2) Kesulitan melakukan interaksi sosial

3) Bertingkah laku sama terus-menerus, dan memili ketertarikan yang sempit serta obsesif. (Simone Griffin dan Dianne Sandler,2010:2)

Menurut PA (American Psychiatric Assosiation) telah menetapkan krikteria Diagnostik Gangguan Spektrum Autisme, berdasarkan Statistical Manual of Mental Disorder IV, lebih lanjut sebgaaimana yang dikutip Kak Kresno sebagai berikut:

1. Harus ada sedikit gejala dari (1), (2), dan (3):

a) Gangguan kualitatif dalam interaksi sosial yang timbale balik. Minimal harus ada 2 dari gejala gejala di bawah ini:

1) Tidak mampu menjalin interaksi sosial yang cukup memadai, kontak mata sangat kurang, ekspresi muka kurang hidup, gerak-gerik yang kurang tertuju.

2) Tidak bisa bermain dengan teman sebaya (sesuai dengan usia anak) 
3) Tidak bisa merasakan apa yang dirasakan orang lain

4) Kurangnya hubungan sosial dan emosional yang timbal-balik

b) Gangguan kualitatif dalam bidang komunikasi, seperti ditunjukkan minimal 1 dari gejala-gejala dibawah ini:

1) Bicara terlambat atau bahkan sama seklai tidak berkembang (tak ada usaha un tuk mengimbangi komunikasi dengan cara lain tanpa bicara)

2) Bila bisa bicara, bicaranya tidak dipakai untuk komunikasi

3) Sering menggunakan bahasa yang aneh dan diulang-ulang

4) Cara bermain kurang variatif, kurang imajinatif, dan kurang bias meniru.

c) Ada suatu pola yang dipertahankan dan diulang-ulangi dalam perilaku, minat dan kegiatan. Sedikitnya harus ada 1 dari gejala di bawah ini:

1) Mempertahankan satu minat atau lebih, dengan cara yang khas dan berlebih-lebihan

2) Ada gerakan-gerakan aneh yang khas dan diulang-ulang

3) Sering kali sangat terpukau pada bagian-bagian benda

2. Gejala-gejala di atas timbul sebelum usia 3 tahun, dan adanya keterlambatan/ gangguan dalam bidang:

1) Interaksi sosial

2) Bicara/ bahasa

3) Cara bermain baik simbolik atau imajinatif

3. Tidak termasuk sindroma Rett, gangguann disintegrasi masa kanak, dan Sindroma Asperger. (Kak Kresno, 2011:11-12)

Dalam persiapan anak autis untuk memasuki sekolah regular, maka dalam pembuatan sebuah kurikulum, perlu diperhatikan beberapa hal, yaitu:

a) Materi atau aktivitas yang diajarkan harus dimulai dengan kepatuhan dan kontak mata. Keduanya harus dikuasai anak dengan baik, semakin konsisten, semakin baik

b) Kemudian, ajarkan kemampuan menirukan dan berlanjutke kemampuan bahasa reseptif atau kognitif. Lanjutkan terus kek kemampuan bahasa ekspresif. Perlu diketahui bahwa kadangkadangdijumpai anak autis yang lebih mudah memahami bahasa reseptif daripada menirukan. Bila hal ini terjai urutan yang biasa boleh saja dimodifikasi 
c) Kemampuan akademik baru diajarkan apabila kemampuan bahasa reseptif telah dikuasai anak

d) Pada awal terapi mulailah dengan jumlah aktivitas yang kecil

e) Bila ternyata kemampuan anak tinggi, jumlah aktivitas yang diajarkan boleh disesuaikan

f) Urutan aktvitas yang diajarkan sebaiknya konsisten agar lebih mudah dikuasai anak

g) Perlu diingat bahwa cara mengajarkan tiap aktivitas adalah dengan siklus DTT. Kecuali kepatuhan dan kontak mata yang diajarkan dengan cara DTT yang khusus. (Y. Handojo, 2009:254)

Adapun layanan pendidikan bagi penderita Autis ini pada program inklusi dengan daya ukur keberhasilan bila ada:

a) Keterbukaan dari sekolah umum

b) Test masuk tidak didasari hanya oleh test $I Q$ untuk anak normal

c) Peningkatan SDM/guru terkait

d) Proses shadowing/ dapat dilaksanakan guru pendamping khusus (GPK)

e) Idealnya anak berhak memilih pelajaran yang ia mampu saja (mempunyai IEP/ program pendidikan individu sesuai dengan kemampuannya)

f) Anak dapat tamat (bukan lulus) dari sekolahnya karena telah selesai melewati pendidikan di kelasnya bersama-sama teman sekelasnya/peers.

g) Tersedianya tempat khusus (special unit) bila anak memerlukan terapi 1:1 di sekolah umum. (Ganda Sumekar, 2009:285-286)

Menurut Yosfan Azwandi, sebaiknya anak autistk didampingi oleh seorang guru pembimbing khusus (GPK) dan guru pendamping/shadow. Guru pembimbing khusus adalah ortopedagog (tenaga ahli PLB) yang bertugas sebagai:

a) Konsultan dalam menangani anak

b) Ikut serta dalam merencanakan program pembelajaran

c) Memonitor pelaksanaan program pembelajaran

d) Mengevaluasi pelaksanaan program pembelajaran. (Yosfan Azwandi, 2005: 140)

Anak autisme mempunyai cara berfikir yang berbeda dan kemampuan yang tidak merata disemua bidang, misalnya pintar matematika, tapi tidak suka menulis dsb. Ciri khas anak autisme sebagai berikut: 
a) Anak tidak dapat mengikuti jalan pikiran orang lain

b) Anak tidak mempunyai empati dan tidak tahu apa reaksi orang lain atas perbuatannya

c) Pemahaman anak sangat kurang, shingga apa yang ia baca sukar dipahami. Misalnya dalam bercerita kembali dan soal berhitung yang menggunakan kalimat

d) Anak kadang mempunyai daya ingat yang sangat kuat, seperti perkalian, kalender, dan lagu-lagu

e) Anak lebih mudah belajar memahami lewat gambar-gambar (visual-learners)

f) Anak belum dapat bersosialisasi dengan teman sekelasnya, seperti sukar bekerjasama dalam kelompok, bermain peran dsb.

g) Anak sukar mengekspresikan perasaannya, seperti mudah frustasi bila tidak dimengerti dan dapat menimbulkan tantrum. (Ganda Sumekar, 2009:286)

Akibat dari gangguan saraf yang di deritanya, seringkali anak autis mengalami kesulitan belajar, yang mempengaruhi kemampuannnya menyimpan, memproses, atau memproduksi informasi. Walaupun intelegensinya tergolong tinggi atau cukup, kesulitan belajar membuat anak lemah atau mempunyai masalah dalam satu atau beberapa mata pelajaran di sekolah, misalnya membaca, menulis, bahasa, matematika, IPS, atau geografi.

Bonny Danuatmaja (2005:176) memparakan biasanya, terapi ini diberikan bagi anak yang mengalami kesulitan belajar atau specific learning disability sehingga terapis harus memberikan remediasi atau pengulangan kembali konsep-konsep atau materi yang diberikan sekolah mulai dari awal, secara one on one atau satu guru satu murid. Dengan adanya terapi ini diharapkan siswa dapat mengingat kembali pelajaran yang telah dipelajari dengan guru di kelas. 


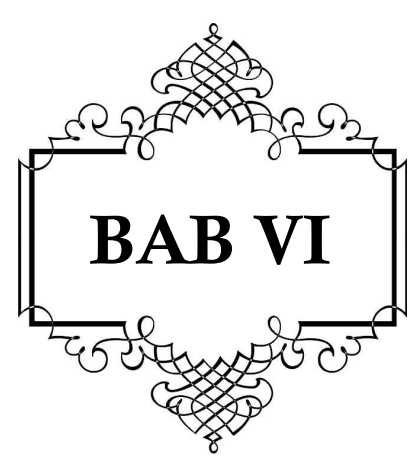

\section{PEMBELAJARAN PENDIDIKAN AGAMA ISLAM}

Setelah membaca bab ini pembaca diharapkan:

* Memahami konsep dasar Pembelajaran Pendidikan Agama Islam

* Memahami landasan pembelajaran pendidikan Agama Islam

* Mengetahui ruang lingkup PembelajaranPendidikan Agama Islam

* Mengetahui isu-isu terkini tentang pendidikan Agama Islam

\section{A. Konsep Dasar Pembelajaran Pendidikan Agama Islam}

Menurut Rusman (2014:134) pembelajaran pada hakikatnya merupakan suatu proses interaksi antara guru dengan siswa, baik interaksi secara langsung seperti kegiatan tatap muka maupun secara langsung, yaitu dengan menggunakan berbagai media pembelajaran.

Barry Moris (Rusman, 2014:135) mengklasifikasikan empat pola pembelajaran, sebagai berikut; 
1. Pola Pembelajaran Tradisional 1

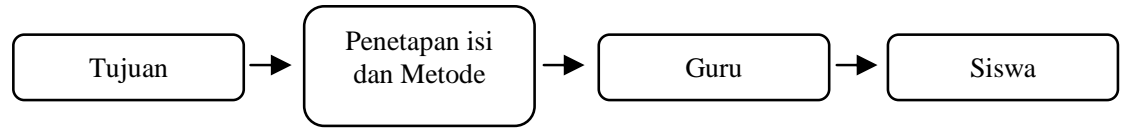

2. Pola Pembelajaran Tradisional 2

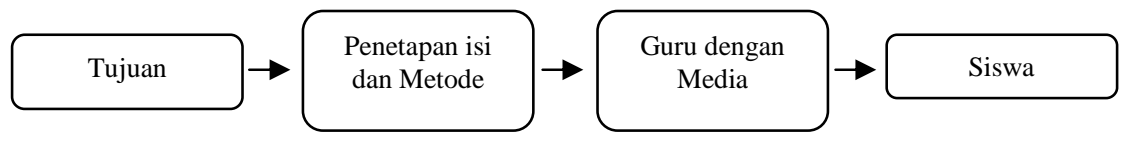

3. Pola Pembelajaran Guru dan Media

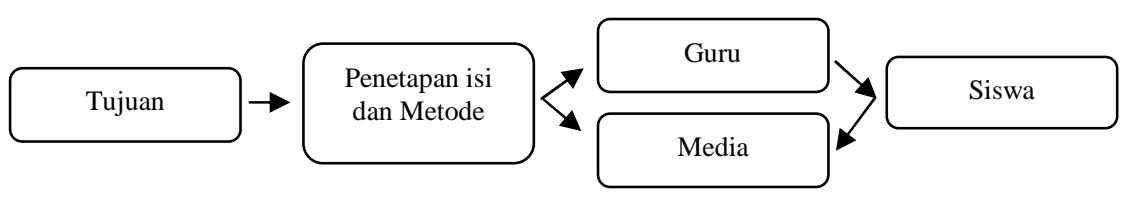

4. Pola Pembelajaran Bermedia

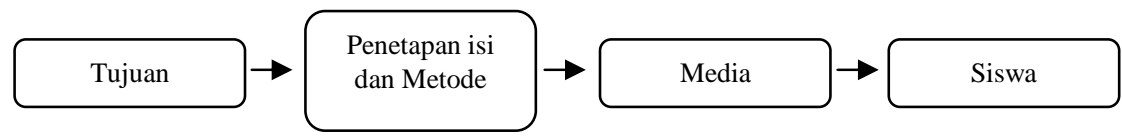

Dari gambar diatas terlihat bahwa perkembangan media pembelajaran berdampak kepada peran guru sebagai penyampai pesan. Dalam pola tersebut guru bukan hanya satu-satunya sebagai sumber belajar, yang disebabkan karena siswa dapat memperoleh informasi dari media yang tesedia, seperti; televisi, radio, internet, VCD, tabloid, dan lainnya.

Dalam pendidikan islam peran seorang guru sangat dominan dalam memberikan pelajaran. Menurut Zakiah Darajat (1992:39), dalam bukunya Ilmu Pendidikan Islam menyatakan bahwa: Guru adalah pendidik profesional, karenanya secara implisit telah merelakan dirinya menerima dan memikul sebagian tanggungjawab pendidikan yang di pundak para orang tua.

Muhaimin menuturkan (2005:51) guru Pendidikan Agama Islam yang profesional adalah orang yang menguasai ilmu pengetahuan Agama Islam sekaligus mampu melakukan transfer ilmu pengetahuan Agama Islam, internalisasi, serta implementasi), mampu menyiapkan peserta didik agar dapat tumbuh dan berkembang kecerdasan dan daya kreasinya untuk 
kemaslahatan diri dan masyarakatnya, mampu menjadi model atau sentral identifikasi diri dan konsultan bagi peserta didik, memiliki kepekaan informasi intelektual dan moral-spiritual, serta mampu mengembangkan bakat, minat dan kemampuan peserta didik dan mampu menyiapkan peserta didik untuk bertanggung jawab dalam membangun peradaban yang diridhai oleh Allah.

Maka dari itu agar proses interaksi akan berjalan dengan baik apabila pendidik dan peserta didik memiliki ikatan emosional yang harmonis baik di dalam kelas maupun diluar kelas, baik di sekolah ataupun di luar sekolah. Harmonisasi dalam kehidupan antara pendidik dan peserta didik baik di lingkungan formal (sekolah) maupun non formal (masyarakat) harus terbina dengan baik layaknya sang anak dengan orang tuanya sendiri, sehingga peserta didik merasakan keberadaan pendidik sendiri sebagai orang yang dihormati, disegani, dan teladani dalam kehidupan sehari-hari.

Konsep hubungan anak dengan orang tua yang diharapkan disini adalah hubungan emosional yang memberikan keleluasaan antara pendidik dan peserta didik untuk memberikan umpan balik yang positif, baik dari pendidik kepada peserta didik maupun sebaliknya.

Sebagai contoh, ketika sang anak merasakan ketakutan akan suatu bahaya yang akan datang padanya maka sang anak akan serta merta lari menghampiri orang tuanya untuk mendapatkan perlindungan, karena dia merasa satu-satunya tempat sang anak tersebut untuk berlindung hanyalah orang tuanya. Begitu pula dengan orang tua yang merasakan akan bahaya yang akan menghampiri anaknya, maka orang tua tersebut pasti akan memberikan peringatan, nasehat, hingga sebuah perlindungan jika sang anak tidak sanggup untuk menghadapi bahaya yang datang.

Peserta didik yang sudah memberikan ruang kepada Pendidik baik sebagai Bapak atau ibu, Saudara hingga menjadi seorang sahabat dekat tempat berbagi baik suka maupun duka. Maka pembelajaran akan tercapai dengan baik sesuai dengan apa yang diharapkan baik orang tua, pendidik, maupun peserta didik itu sendiri karena dengan keterbukaan dan penerimaan dinding pemisah antara ilmu yang ada pada pendidik akan dengan mudah ditransfer kepada peserta didik.

Begitu pula dengan hubungan pendidik dan peserta didik dalam pembelajaran pendidik dengan ramah menyambut peserta didik, menyemangati peserta didik agar dapat mencapai cita-cita sebagaimana yang diinginkan peserta didik dan juga memberikan solusi maupun nasehat ketika peserta didik mengalami suatu permasalahan baik dalam pelajaran 
hingga permasalahan pribadi yang sedang dialaminya. Di kelas jadi Orang Tua, di Luar Jadi Sahabat.

Ketika hubungan antara pendidik dan peserta didik berjalan dengan harmonis sebagaimana hubungan antara orang tua dan anaknya maka kita akan menemukan seorang pendidik yang all out dalam memberikan segala yang ia miliki untuk tercapainya tujuan pembelajaran tanpa memandang cerdas atau tidak, miskin atau kaya, etnis, ras, ataupun penyandang disabilitas.

Keberhasilan interaksi antara pendidik dengan peserta didik akan menghantarkan kepada proses selanjutnya yakni pemanfaatan sumber belajar sesuai dengan kebutuhan.

Sumber belajar seringkali dijadikan oleh sebagian orang tua sebagai hal nomor dua dalam kelancaran sekolah setelah seragam sekolah. Hal ini tercipta karena seringnya pengusiran yang dilakukan Oknum Pendidik yang mengagungkan peserta didik yang memiliki buku teks dan mendiskriditkan yang lain. Sumber belajar yang kita maksudkan disini bukan hanya buku pegangan siswa yang menjadi satu-satunya sumber belajar, akan tetapi sumber belajar lainnya seperti, alat atau media pembelajaran yang disajikan oleh guru, perpustakaan, maupun sarana lainnya yang terkait dengan materi yang akan dipelajari itu sendiri.

Pendidikan Agama Islam merupakan salah satu materi wajib yang akan didapatkan oleh setiap peserta didik yang berlatar belakang Agama Islam. Pelajaran PAI sendiri diajarakan semenjak dari kelas 1 (satu) pada tingkatan sekolah dasar hingga kelas 12 (dua belas) paada tingkatan Sekolah Menengah Atas. Pelajarn PAI sendiri akan dibimbing oleh seorang guru mata pelajaran agama pada masing-masing tingkatan.

\section{B. Landasan Historis PAI}

Sebelum Indonesia merdeka mata pelajaran Pendidikan Agama Islam belum diajarkan di sekolah-sekolah negeri. Pelajaran Agama Islam hanya dapat ditemui pada lembaga pendidikan yang diselenggarakan oleh masyarakat, yayasan, ataupun organisasi keagamaan seperti Pesantren dan Madrasah. Proses masuknya Pendidikan Agama Islam kedalam kerangka kurikulum nasional dilakukan secara bertahap. Untuk wilayah Sumatera diprakarsai oleh Mahmud Yunus (1995:128), dimana beliau ketika menjabat sebagai kepala bagian Islam pada Jawatan Agama Propinsi Sumatera. Beliau mengusulkan kepada kepala Jawatan P.P.K. Propinsi Sumatera yakni Abdullah Nawawi untuk memasukkan pelajaran Agama dalam proses belajar mengajar di sekolah-sekolah negeri mulai dari S.R hingga S.M.A. Apa yang menjadi keinginan dari Mahmud Yunus tersebut di 
sambut baik oleh Abdullah Nawawi, sehingga apa yang rencana pengajaran agama yang sudah di tetapkan di Sumatera Barat dapat diterimanya dengan baik.

Pada tahun yang sama dikeluarkannya penetapan bersama antara Menteri Pengajaran, Pendidikan dan Kebudayaan dan Menteri Agama (Mahmud Yunus,1995:357). Nomor: 1285/K-7 Tahun 1946 (Agama) dan nomor: 1142/Bhg.A (Pengajaran). Hasil dari penetapan bersama tersebut dijelaskan bahwa Pendidikan Agama hanya dapat diberikan mulai kelas empat S.R., sedangkan pada kelas satu sampai tiga, pendidikan Agama tidak boleh diajarkan. Untuk membuat rencana pengajaran Agama dibentuk badan Penasehat yang bernama Majelis Pertimbangan Pengajaran Agama Islam yang dipimpin Ki Hajar Dewantoro dan Drs. Abdullah Sigit.

Ketika diadakan Konfrensi Pendidikan dan Pengajaran yang pada tanggal 2-10 Maret 1947 oleh kepala Jawatan P.P.K. Propinsi Sumatera di Padang Panjang. Dimana pada acara tersebut dihadiri oleh para inspektur dan pemeriksa-pemeriksa sekolah seluruh Sumatera, serta undangan lainnya. Mahmud Yunus menyampaikan saran agar pendidikan dan pengajaran agama dimasukkan kedalam renacana pengajaran sekolahsekolah negeri mulai dari kelas satu S.R hingga kelas tiga S.M.A. usulan beliau diterima dengan suara bulat sehingga ditetapkan, bahwa pendidikan dan pengajaran agama dimasukkan dalam sekolah-sekolah negeri sejak dari kelas satu S.R. hingga kelas tiga S.M.A. dengan jumlah jam pelajaran dua jam pada tiap-tiap kelas.

Dalam rangka desiminasi tentang proses belajar mengajar Agama Islam di sekolah-sekolah negeri pada tanggal 1-30 Juni 1947 diadakan kursus guru-guru agama di Pematang Siantar. Adapun pesertanya merupakan seorang guru agama yang terpandai di kabupatennya masingmasing. Adapun materi yang ditekankan dalam kursus ini adalah bagaimana cara melancarkan dan melaksanakan rencana pengajaran agama terutama dari kelas satu hingga enam S.R. baik teori atau praktek.

Pada tahun 1950 setelah Pemerintah Republik Indonesia Serikat berpusat di Jakarta, dimulailah rencana Pendidikan Islam untuk seluruh Indonesia. Saat itu Mahmud Yunus yang dipindahkan dari Kementrian Agama Republik Indonesia di Yogyakarta ke Kementrian Agama R.I.S. Jakarta, ia bersama Mr. Sunaryo yang saat itu sebagai Sekjen Kementrian Agama Yogyakarta mengadakan kompromi antara rencana Sumatera dengan rencana Kementrian Agama Yogyakarta. Selama beberapa kali pertemuan yang juga melibatkan Mr. Hadi yang merupakan Sekjen Kementrian P.P.K. akhirnya ditetapkan Peraturan Bersama oleh 
Kementrian P.P.K. nomor: 1432/Kab dan nomor K.1/651 oleh Kementrian Agama yang bertepatan dengan tanggal 20 Januari 1951.

Berikut kutipan dari Pasal 2 Peraturan bersama tersebut; 1) Di sekolah-sekolah rendah pendidikan Agama dimulai pada kelas IV, banyakanya 2 (dua) jam dalam Satu minggu. 2) Di lingkungan yang istimewa pendidikan Agama dapat dimulia pada kelas I dan jamnya dapat ditambah menurut kebutuhan, tetapi tidak melebihi 4 jam seminggu dengan ketentuan, bahwa mutu pengetahuan umum, bagi sekolah-sekolah rendah itu tidak boleh dikurangi dibandingkan dengan sekolah-sekolah rendah di lain-lain lingkungan. Kemudian dalam Pasal 3 dibunyikan; Di sekolah-sekolah lanjutan tingkat pertama dan tingkatan atas, baik sekolahsekolah umum, maupun sekolah-sekolah vak, diberi pendidikan Agama dua Jam dalam tiap-tiap minggu. Dengan lahirnya peraturan tersebut maka pendidikan agama secara resmi masuk kedalam pelajaran sekolah-sekolah umum.

Setelah peraturan tersebut Menteri Agama membentuk kepanitiaan yang diketuai oleh Kiyai Imam Zakasyi dari Pondok Pesantren Modern Gontor untuk membuat Rencana pengajaran Agama Islam disekolahsekolah negeri tersebut. Rapat yang diadakan di Yogyakarta beberapa kali tersebut melahirkan sebuah ketetapan yang disahkan oleh Menetri Agama nomor 21 tahun 1952. Selanjutnya di Bandung melahirkan rencana pengajaran utuk sekolah lanjutan pertama. Dikarenakan Panitia Perencana Pendidikan Agama Islam tidak bekerja lagi, maka rencana pengajaran agama untuk S.M.A. dibuat oleh Lembaga Pendidikan Agama (Japenda) sementara waktu. Selanjutnya pada tanggal 1 Oktober 1953 dibentuk Majelis Pertimbangan Pendidikan dan Pengajaran Agama yang diketuai oleh Imam Zarkasyi. Sementara panitia Perencana Pendidikan Agama Islam di bubarkan.

Pemerintah, selanjutnya melalui Majelis Permusyawaratan Rakyat Sementara (MPRS) pada bulan Desember 1960 melahirkan keputusan yang menyatakan dalam Pasal 3 yang berbunyi; bahwa agama menjadi mata pelajaran di sekolah umum, mulai dari sekolah dasar hingga perguruan tinggi, dengan ketentuan, bahwa murid berhak ikut serta dalam pendidikan agama jika wali murid atau murid dewasa menyatakan tidak keberatan. (Abuddin Nata, 2014: 321)

Selanjutnya pada tahun 1989 lahirlah undang-undang nomor 2 Tahun 1989 Tentang Sistem Pendidikan Nasional yang memasukkan pendidikan Islam mulai dari Taman Kanak-kanak hingga perguruan Tinggi sebagai bagian dari sistem pendidikan nasional yang berhak mendapatkan 
perlakuan yang sama dalam bidang regulasi, bantuan keuangan, dan sumber daya manusia. (Abuddin Nata, 2014: 334)

\section{Ruang Lingkup Pembelajaran Agama Islam}

Pendidikan Agama Islam (PAI) merupakan salah satu mata pelajaran yang masuk ke dalam kurikulum Nasional. Oleh karenanya, mata pelajaran PAI selalu ada dalam kurikulum sekolah, baik Sekolah Negeri atau Swasta. Harapannya mata pelajaran PAI mampu mendorong siswa untuk menumbuhkan karakter dan kepribadian yang luhur. Haidar Putra Daulay (2004:222) Pendidikan Islam berupaya mengembangkan individu yang utuh yang dapat mewarisi nilai-nilai Islam. Pendidikan Islam idealnya yang tujuan dan dasar-dasarnya berdasarkan kepada ruh Islam yang dituangkan Allah dalam Al-Quran dan dicontohkan Rasul dalam Hadits. Pendidikan yang berdasarkan kepada Realita masyarakat dan lingkungan yang mengitarinya, juga berdasarkan kepada nilai yang bersumber dari Agama dan kebudayaannya. (DepDikNas,2004: 32)

Sebagai mata pelajaran pokok, mata pelajaran Pendidikan Agama Islam (PAI) dalam Permendiknas Nomor 23 tahun 2006 tentang Standar Kompetensi Lulusan yang harus dicapai siswa diantaranya: 1) Alqur'an, 2) Aqidah, 3) Tarikh, 4) Akhlak, 5) Fiqih.

Materi Al-Qur'an yang diberikan biasanya berisi tentang ayat-ayat yang disesuaikan dengan pembahasan seperti keimanan, perilaku sosial atau yang lainnya. Hal ini bertujuan agar ayat-ayat tersebut dipahami serta dihafal oleh peserta didik. Dalam materi aqidah materi-materi yang diberikan terkait dengan penguatan keimanan peserta didik tentang Allah, Malaikat, Rasul, Qadha, dan Hari Akhir. Selanjutnya materi Tarikh berisi tentang kisah-kisah yang dapat menjadi ibrah bagi peserta didik agar dapat meneladani perilaku yang baik dan meninggalkan perilaku yang tidak baik.

Begitu juga dengan materi akhlak lebih kepada memberikan contohcontoh keteladanan sehingga peserta didikm dapat menjadi hamba yang shaleh dan shalehah. Untuk materi Fiqih, biasanya berisi tentang tuntunan hukum-hukum yang telah ditetapkan oleh para ulama sehingga peserta didik dapat berpegang dan mengaplikasikan dalam kehidupan sehari-hari.

\section{Isu-isu Pendidikan Agama Islam}

Berbagai kritikan terus mengalir dari berbagai pengamat yang bersal dari kalangan islam sendiri, bahwa pelajaran Agama Islam yang diajarakan belum dapat menyelesaikan permasalahan kenakalan remaja yang sudah sangat memprihatinkan. Muklai dari permasalahan umum seperti merokok, perkelahian hingga permalahan yang dilaur nalar orang tua 
seperti; Pergaulan Bebas, Narkoba, Minuman Keras, Tawuran, Perkosaan, Pembunuhan, hingga bunuh diri.

Kalau dapat kita renungkan sejenak tentang tujuan orang tua menitipkan anaknya kepada sekolah tentu kita akan menemukan jawaban akan sebuah harapan yang sangat besar agar anak mereka dapat menjadi anak yang shaleh dan shaleh dan memiliki ilmu pengetahuan dan mengusai teknologi moderen.

Lalu, kenapa peristiwa-peristiwa yang telah disebutkan di atas masih terjadi? Syaithan, merupakan penyebab dibalik semuanya, akan tetapi sebelum menyalahkan tokoh utama tersebut, mari kita kaji si manusianya yang melakukan suruhan-suruhan syaithan tersebut. Beberapa pertanyaan dapat kita pertanyakan, diantaranya; bagaimana suasana pembelajaran agamanya di kelas? Layakkah gurunya untuk di teladani? apakah dalam bergaul bersama dengan anak-anak yang shaleh/ shalehah? sudahkah betul shalat yang dilakukan? bagaimana hubungan dalam keluarga? Sejauh mana pemahamnnya tentang agama islam itu sendiri?

Penulis yakin dengan menjawa beberapa pertanyaan di atas dengan jujur, maka permasalahan sebenarnya akan dapat ditemukan apakah penyebab utamanya, Guru, Sekolah, Teman, Anak, Atau orang tuanya sendiri.

Maka dari itu mari kita rangkul diri kita sendiri kepada ajaran islam yang shahihah, kemudian menjadikan keluarga yang sakinah akan memiliki dampak yang luar biasa dalam memilih sekolah, pergaulan dan memandang hal-hal yang baru dengan pendekatan aqidah yang telah dipupuk sedari kecil.

Peran dari pihak sekolah tentu sangat diharapkan dapat membantu perkembangan seorang anak yang dititipkan dengan pakaian seragam lengkap hendaknya ketika lulus menjadi anak yang sesuai dengan harapan orang tua. Tentunya kerjasama menjadi kata kunci dari semua pembahasan ini, dengan komunikasi yang intens, fleksibel, dan jujur dapat menyelesaikan permasalahan yang terjadi terhadap generasi muda kita. 


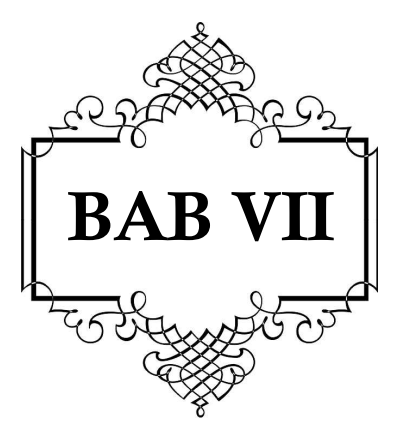

\section{KURIKULUM UNTUK ANAK BERKEBUTUHAN KHUSUS}

Setelah membaca bab ini pembaca diharapkan:

* Memahami konsep dasar Kurikulum

* Memahami Asas-asas kurikulum

* Mengetahui fungsi kurikulum

* Mengetahui jenis-jenis kurikulum

\# Memahami Implementasi kurikulum untuk anak berkebutuhan khusus

\section{A. Konsep Dasar Kurikulum}

1. Secara Etimologi (Bahasa)

Kurikulum bersal dari bahasa Yunani yang mula-mula digunakan dalam bidang olah raga, yaitu kata "curere", yang berarti jarak tempuh lari. (M. Ahmad,1998:9) Menurut kamus Webster tahun 1856. Artinya pada waktu itu ialah: 1. "a race course; place for running; a chariot. 2. a course in general; applied particulary to the course of study in university" (S.Nasution, 1995:1). Sedangkan menurut pendapat lain, kurikulum berasal dari bahasa Latin, yaitu "curiculae" artinya jarak yang harus di tempuh oleh seorang pelari pada waktu itu (Oemar Malik, 1999:16)

\section{Secara Terminologi (Istilah)}

Syarifuddin Nurdin (2005:32) Kurikulum ialah sejumlah mata pelajaran di sekolah atau di akademisi/college yang harus di tempuh oleh siswa untuk mencapai suatu degree (tingkat) ijazah.

Menurut John dewey kurikulum merupakan suatu rekonstruksi berkelanjutan yang memparkan pengalaman belajar anak didik melalui 
suatu susunan pengetahuan yang terorganisasikan dengan baik. Sedangkan menurut Ralph Tyler kurikulum adalah seluruh pengalaman belajar yang direncanakan dan diarahkan sekolah untuk mencapai tujuan pendidikannya (M. Ahmad,1998:13).

Sedangkan menurut Edward A. Krug (S.Nasution, 1995:4-8) memaparkan kurikulum adalah sebagai cara-cara dan usaha untuk mencapai tujuan sekolah. Kemudian J. Wiles \& J. Bondi menambahkan kurikulum adalah suatu cita-cita atau seperangkat nilai-nilai, yang digerakkan melalui suatu pengembangan proses kulminasi dalam pengalaman-pengalaman dikelas untuk murid-murid. Tingkat terhadap pengalaman-pengalaman tersebut merupakan suatu representasi yang benar terhadap cita-cita yang diimpikan ialah suatu fungsi langsung daripada efektivitas dari usaha-usaha pengembangan kurikulum (Abdullah Idi, 1999:4-5)

Di dalam pasal 1 butir ke-19 dalam Undang-undang nomor 20 tahun 2003 tentang Sistim Pendidikan Nasional kurikulum diartikan sebagai Seperangkat rencana dan pengaturan mengenai tujuan, isi, dan bahan pelajaran serta cara yang digunakan sebagai pedoman penyelenggaraan kegiatan pembelajaran untuk mencapai tujuan pendidikan tertentu

Berbagai tafsiran tentang kurikulum diatas, dapat digolongkan (S.Nasution, 1995:9) sabagai berikut:

1. Kurikulum dapat dilihat sebagai produk, yakni sebagai hasil karya para pengembang kurikulum, biasanya dalam suatu panitia. Hasilnya dituangkan dalam bentuk buku atau pedoman kurikulum, yang misalnya berisi sejumlah mata pelajaran yang harus diajarkan .

2. Kurikulum dapat pula dipandang sebagai program, yakni alat yang dilakukan oleh sekolah untuk mencapai tujuannya. Ini dapat juga meliputi segala kegiatan yang dianggap dapat mempengaruhi perkembangan siswa, misalnya, perkumpulan sekolah, pertandingan, pramuka, warung sekolah dan lain-lain.

3. Kurikulum dapat pula dipandang sebagai hal-hal yang harapkan akan dipelajari siswa, yakni pengetahuan, sikap keterampilan tertentu. Apa yang diharapkan akan dipelajari tidak selalu sama dengan apa yang benar-benar di pelajari.

4. Kurikulum sebagai pemahaman siswa. Ketiga pandangan diatas berkenaan dengan perencanaan kurikulum sedangkan pandangan ini mengenai apa yang secara aktual menjadi kenyataan pada tiap siswa. Ada kemungkinan, bahwa apa yang diwujudkan pada diri anak berbeda dengan apa yang diharapkan menurut bersama. 
Dapat disimpulkan bahwa kurikulum merupakan seperangkat pelajaran yang harus diberikan kepada siswa dengan metode tertentu dan pengalaman belajar yang relevan dengan tujuan pembelajaran di bawah tanggung jawab sekolah.

\section{B. Asas-asas Kurikulum}

Dalam mengembangkan kurikulum banyak hal yang harus diperhatikan dan dipertimbangkan sebelum mengambil keputusan. Dalam mengembangkan kurikulum memerlukan asas-asas yang harus dipegang. Asas-asas tersebut tidaklah rumit, akan tetapi harus dengan pemahaman yang cukup dengan asas-asas tersebut dan tidak melupakan kebutuhan pendidikan dimana pengembangan kurikulum dibutuhkan.

Pengembangan kurikulum pada suatu Negara dengan Negara lain, apakah negara-negara berkembang (developing Countries), negara terbelakang (under developing countries), bisa dipastikan mempunyai perbedaan-perbedaan dan mungkin mendasar, tetapi tetap ada persamaanpersamaannya.

Falsafah yang berlainan, otoriter, demokrasi, sekuler atau relijius, akan memberi warna yang berbeda dalam kurikulum yang dimiliki oleh bangsa bersangkutan. Begitu juga apabila dilihat dari perbedaan masyarakat, organisasi bahan yang digunakan, dan pilihan psikologi belajar pada tiap-tiap Negara tersebut.

Sebelum merobah sebuah kurikulum atau mengembangkan kurikulum, maka perlu meyakinkan bahwa langkah tersebut merupakan sebuah keputusan yang mantap dan tepat sasaran. Untuk lebih terarahnya para pengembang kurikulum dalam pandangan S.Nasution (1995: 10-11) maka perlu rasanya untuk menjawab beberapa pertanyaan dibawah:

1. Apakah yang ingin dicapai ?

2. Manusia bagaimana yang diharapkan akan dibentuk ?

3. Apakah akan diutamakan kebutuhan anak pada saat sekarang atau pada masa yang akan datang ?

4. Apakah hakikat anak harus dipertimbangkan, ataukah ia diperlakukan sebagai orang dewasa?

5. Apakah kebutuhan anak itu ?

6. Apakah harus dipentingkan anak sebagai individu atau sebagai kelompok?

7. Apa yang harus dipentingkan, mengajarkan kejujuran atau member pendidikan umum?

8. Apakah pelajaran akan didasarkan atas disiplin ilmu ataukah dipusatkan pada masalah sosial dan pribadi? 
9. Apakah semua anak harus mengikuti pelajaran yang sama ataukah ia diizinkan memilih mata pelajaran sesuai dengan minatnya ?

10. Apakah semua kurikulum sama bagi semua sekolah secara uniform, atau diberi kelonggaran untuk menyesuaikannya dengan keadaan daerah?

11. Apakah hasil belajar anak diuji secara uniform ataukah diserahkan pada penilaian guru yang dapat mempelajari anak dalam segala aspek selama waktu yang panjang?

Beberapa pertanyaan diatas merupakan sebuah instrument untuk mengarahkan dalam mengembangkan kurikulum yang sesuai dengan apa yang diinginkan oleh para pengembang kurikulum.

Dengan adanya sebuah visi dan misi yang sudah jelas oleh para pengembang kurikulum, maka langkah selanjutnya adalah memperhatikan beberapa asas-asas kurikulum yang menjadi titik tolak untuk pengembanagn kurikulum. Asas-asas tersebut adalah:

1. Asas Filosofis

Filsafat diartikan sebagai ilmu yang berusaha untuk memahami semua hal yang muncul didalam keseluruhan lingkup pengalaman manusia, yang mana diharapkan agar manusia dapat mengerti dan mempunyai pandangan yang menyeluruh dan sistematis mengenai alam semesta dan tempat manusia didalamnya, manusia merupakan bagian dari dunia (Abdullah Idi,1999: 57).

Pandangan yang menyeluruh dan sistematis yang diharapkan dapat dikuasai oleh manusia tersebut adalah lebih dari pengetahuan. Barangkali yang dimaksud dikuasia disini adalah pengetahuan itu sendiri, dan yang dapat menemukan saling hubungan dan pertalian dari semua unsur, sehingga ditemui kedalaman mengenai kebijakan (S.Nasution, 1995:57).

Sebagai induk dari semua pengetahuan (the mother of knowledge), menurut Abdullah Idi (1999: 57) filsafat dapat dirumuskan sebagai kajian tentang:
a. Metafisika, yakni studi tentang hakekat kenyataan atau realitas
b. Efistimologi, yakni studi tentang pengetahuan
c. Aksiologi, yakni studi tentang nilai
d. Etika, yakni studi tentang kebaikan
e. Estetika, yakni studi tentang keindahan
f. Logika, yakni studi tentang hakekat penalaran

Apabila diamati dari item-item yang ada diatas, tampaknya filsafat mempunyai jangkauan yang sangat luas. Bagi para pengembang kurikulum 
yang memiliki pemahaman yang kuat tentang rumusan filsafat diatas. Maka akan memberikan dasar yang kuat pula kemungkinan dalam mengambil suatu keputusan yang tepat dan konsisten.

Diharapkan dalam mengembangkan sebuah kurikulum hendaknya para pengembang kurikulum tidak menonjolkan kepentingan-kepentingan pribadi mereka. Para pengembang kurikulum harus mempunyai filsafat yang jelas tentang apa yang mereka junjung tinggi. Filsafat yang kabur akan menimbulkan kurikulum yang tidak menentu arahnya.

Di dalam buku asas-asas kurikulum karangan S. Nasution (1995:57) dijelaskan ada beberapa aliran filsafat yang mempengaruhi suatu kurikulum yang akan dijalankan tersebut, diantaranya, aliran Perennialisme, Aliran Idealisme, Aliran Realisme, Aliran Pragmatisme, dan Aliran Eksistensialisme. Berikut penjelasan aliran-aliran filsafat tersebut:

a. Aliran Perennialisme

Aliran ini bertujuan mengembangkan kemampuan intelektual anak melalui pengetahuan yang "abadi, universal, dan Absolut", atau "perennial" yang ditemukan dan diciptakan para pemikir unggul sepanjang masa, yang dihimpun dalam the great books, atau buku agung. Kebenaran buku ini beretahan teguh terhadap segala perubahan zaman

Kurikulum yang diinginkan oleh kurikulum ini adalah berupa subject atau mata pelajaran yang terpisah sebagai disiplin ilmu sebagai penolak penggabungan seperti IPA atau IPS. Hanya mata pelajaran yang susngguh mereka anggap dapat menggembangkan kemampuan intelektual seperti, matematika, fisika, kimia, biologi yang diajarkan, sedangkan yang berekenaan emosi dan jasmani seperti seni rupa, olah raga sebaiknya di kesampingkan. Pelajaran yang diberikan termasuk pelajaran yang sulit karena membutuhkan tingkat intelejensi yang tinggi kurikulum ini member persiapan yang sungguh-sungguh bagi studi di perguruan tinggi.

\section{b. Aliran Idealisme}

Filsafat ini berpendapat bahwa kebenaran itu berasal dari "atas", dari dunia supra-natural, dari tuhan. Boleh dikatakan hamper semua agama menganut aliran idealism. Kebenaran dipercayai datangnya dari tuhan yang diterima melalui wahyu. Kebenaran ini termasuk dogma-dogmanya yang bersifat mutlak . apa yang dating dari tuhan baik dan benar. Tujuan hidup ialah memenuhi kehendak tuhan.

Filsafat ini umumnya diterapkan disekolah yang berorientasi relijius. Semua siswa diharuskan mengikuti pelajaran agama, menghadiri khotbah dan membaca kitab suci. Biasanya disiplin termasuk ketat, pelanggaran diberikan setimpal bahkan dapat dikeluarkan dari sekolah. Namun 
pendidikan intelektual juga sangat diutamakan dengan menentukan standar mutu yang tinggi.

c. Aliran Realisme

Filsafat realisme mencari kebenaran di dunia ini sendiri. Melalui pengamatan dan penelitian ilmiah dapat dikemukakan hukum-hukum alam. Mutu kehidupan senantiasa di tingkatkan dengan ilmu pengetahuan dan teknologi. Tujuan hidup ialah memperbaiki kehidupan melalui penelitian ilmiah.

Sekolah yang beraliran realisme ini mengutamakan pengetahuan yang sudah mantap sebagai hasil penelitian ilmiah yang dituangkan secara sistematis dalam berbagai disiplin ilmu atau mata pelajaran. Di sekolah akan dimulai dengan prinsip-prinsip yang fundamental, kemudian praktik dan aplikasinya.

Karena mengutamakan pengetahuan yang esensial, maka kurikulum ini tidak memperhatikan minat anak, hal ini terbukti dengan tidak perlunya mempelajari keterampilan dan kesenian, namun diharapkan menaruh minat terhadap mata pelajaran akademis.

\section{d. Aliran Pragmatisme}

Aliran ini juga disebut aliran instrumentalisme atau utilitarianisme dan berpendapat bahwa kebenaran adalah buatan manusia berdasarkan pengalamannya. tidak ada kebenaran mutlak, kebenaran adalah tentatif dan dapat berubah. yang baik adalah yang berakibat baik bagi masyarakat. Tujuan hidup ialah mengabdi kepada masyarakat dengan peningkatan kesejahteraan manusia.

Tugas guru bukan mengajar dalam arti menyampaikan pengetahuan, melainkan member kesempatan terhadap anak untuk melakukan berbagai kegiatan guna memecahkan masalah, atas dasar kepercayaan bahwa belajar itu bias dilakukan oleh anak sendiri, bukan karena "dipompakan kedalam otaknya". yang penting bukanlah "what to think"melainkan "how to think" yakni melakukan pemecahan masalah. Pengetahua di peroleh bukan dengan mempelajari mata pelajaran, melainkan karena digunakan secara fungsional dalam pemecahan masalah.

\section{e. Aliran Eksistensialisme}

Filsafat ini mengutamakan individu sebgai factor yang menentukan apa yang baik dan benar/ norma-norma hidup berbeda secara individual dan ditemukan masing-masing secara bebas, namun dengan pertimbangan jangan menyinggung perasaan orang lain. Tujuan hidup adalah menyempurnakan diri, merealisasikan diri. 
Sekolah berdasarkan eksistensialisme mendidika anak agar menentukan pilihan dan keputusan sendiri dengan menolak otoritas orang lain. Ia harus berfikir dan mengambil keputusan sendiri secara bertanggung jawab.

Sekolah ini menolak segala kurikulum, pedoman, instruksi, buku wajib, dan lain-lain dari pihak luar. Anak harus mencari identitasnya sendiri, menentukan standarnya sendiri dan kurikulumnya sendiri. Dengan sendirinya mereka tidak dipersiapkan untuk menempuh ujian nasional.

Selanjutnya Abdullah Idi (1999: 59-60) menerangkan asas Filosofis ini ada 3 (tiga) falsafah yang harus diperhatikan diantara nya:

\section{a. Falsafah Bangsa}

Setiap negara didunia ini, negara berkembang, negara maju, memiliki suatu falsafah atau pandangan pokok mengenai pendidikan. Setiap individu memiliki pandangan tertentu mengenai pendidikan. Yang kadangkala tidak sama dengan pandangan umum. Keberadaan kurikulum adalah perlunya memelihara keutuhan dan persatuan Bangsa dan Negara.

Bagi bangsa Indonesia, falsafah pendidikan bukanlah persoalan, mengingat Pancasila dan UUD 1945 telah diterima secara resmi dan telah dapat diterima semua pihak, bahkan tidak bertentangan dengan falsafah pendidikan Islam atau falsafah agama lain.

Keselarasan pendidikan nasional dengan falsafah pendidikan Islam terletak pada tujuan filosofi pendidikan masing-masing. menurut Undangundang nomor 2 tahun 1989 tentang Sistem Pendidikan Nasional adalah untuk menciptakan manusia Indonesia yang beriman, bertakwa, berbudi pekerti luhur, berakhlak, berketerampilan, tanggung jawab kemasyarakatan dan berbangsa.

Keberadaan falsafah Pancasila harus dijadikan kerangka utama (main-steam) dalam mengontrol pelaksanaan lembaga-lembaga pendidikan pada suatu Negara, karenanya keberadaan falsafah tersebut akan mempengaruhi semua kebijakan dan keputusan dalam pengembangan kurikulum.

b. Falsafah Lembaga Pendidikan

Pancasila merupakan falsafah nasional yang tegas, yang telah diterima oleh segenap bangsa Indonesia. Dalam kontek pendidikan Pancasila sebagai pedoman bagi lembaga pendidikan untuk mengembangkan falsafah atau pandangan masing-masing sesuai dengan misi dan tujuan serta nilai-nilai masyarakat yang terkandung dilayaninya. 
Tiap-tiap lembaga pendidikan, seperti IAIN contohnya, mempunyai misi dalam rangka bagian sistem pendidikan nasional, namun IAIN barangkali mempunyai barangkali mempunyai suatu khas yang ada perbedaannya dengan IAIN di daerah lain. Sama halnya dengan tiap fakultas atau jurusan menunjukkan suatu kekhasan dalam pandangannya sehingga ia memiliki pendekatan (approach) yang berlaianan terhadap pengembnagan kurikulum dalam pelaksanaan pendidikan. Jadi, walaupun banyak persamaan-persamaan diantara fakulktas atau jurusan, sama halnya dengan sekolah-sekolah, tapi ada pula yang menonjol dengan fakultas, jurusan, dan sekolah tempat lain, dimana lembaga pendidikan tersebut berada

\section{c. Falsafah Pendidikan}

Dalam operasional kurikulum peran pendidik memang menduduki posisi yang yang penting, dari segi perencanaan pengorganisasian dan penyampaian pelajaran, merupakan suatu hal yang menentukan tercapainya tujuan pendidikan yang dirumuskan dalam sekolah yang bersangkutan.

Tidaklah berarti sama sekali suatu kurikulum yang baik, namun pendidik memiliki falsafah yang berbeda dalam memahami, menafsirkan dan melaksanakan suatu kurikulum.

Keberadaan falsafah dari pada seseorang pendidik memang sangat berpengaruh terhadap keberhasilan proses belajar mengajar, oleh karenanya, seorang pendidik mesti professional, karena dengan porsi perannya yang di bebankan orang tua murid kepada mereka agar anakaanak mereka mendapatkan pendidikan yang terbaik.

\section{Asas Sosiologis}

Tiap masyarakat mempunyai norma-norma, adat kebiasaan yang dapat diwujudkan anak dalam pribadinya lalu dinyatakan dalam kelakuannya. Tiap masyarakat berlainan corak yang dianutnya. Tiap anak akan berbeda latar belakang kebudayaannya. Perbedaan ini harus diperhatikan dalam kurikulum.

Studi mengenai people in society menekankan pada pendapat tentang kemanusiaana yang dimulai oleh sosiologi dan dilakukan oleh filosoffilosof inggris seperti Hobbes pada abad ke tujuh belas. Mereka merasakan bahwa suatu hal yang penting bagi individu-individu untuk di jaga dalamperaturan, kalau tidak merata akan kacau balau (chaos) karena individu-individu pada dasarnya bersifat rakus dan suka mementingkan diri sendiri (Abdullah Idi,1999: 61) 
Asas Sosiologis mempunyai peran penting dalam mengembangkan kurikulum pendidikan pada masyarakat. Suatu kurikulum pada prinsipnya mencerminkan keinginan, cita-cita tertentu dan kebutuhan masyarakat.

Dengan memperhatikan asas sosiologis dimana masyarakat sebagai parameter untuk melihat kondisi siswa yang berdampak langsung untuk perkembangan mereka. Maka usaha untuk mencerdaskan anak bangsapun akan tercapai, dan permaslahan sosialpun akan terselesaikan.

Kesukaran-kesukaran akan muncul apabila kelompok-kelompok sosial dalam masyarakat, seperti: golongan militer, politik, agama, industri, pemerintah, swasta, ekonomi, dan lain-lain, mengajukan keinginan yang bertentangan dan berkaitan dengan kepentingan kelompok masingmasing. Akhirnya sangat memungkinkan adanya tekanan sumber nasional, dan lain-lain (Abdullah Idi,1999:62).

Dari sudut pandang sosiologis sistem pendidikan serta lembaga pendidikan di dalamnya dapat dilihat sebagai bahan yang memiliki beragam fungsi bagi kepentingan masyarakat, yakni:

a. Mengadakan revisi dan perubahan sosial

b. Mempertahankan kebebasan akademis dan kebebasan melaksanakan penelitian ilmiah

c. Mendukung dan turut memberi kontribusi kepada pembangunan

d. Menyampaikan kebudayaan dan nilai-nilai tradisional dan mempertahankan status quo

e. Mengekploitasi orang banyak demi kesejahteraan golongan elit

f. Mewujudkan revolusi sosial untuk melenyapkan pengaruhpengeruh pemerintah terdahulu.

g. Mendukung kelompok-kelompok tertentu, antara lain, kelompok militer, industri atau politik

h. Menyebarluaskan falsafah, politik atau kepercayaan tertentu

i. Membimbing dan mendidiplinkan jalan fikiran generasi muda

j. Mendorong dan mempercepat laju kemajuan ilmu pengetahuan dan teknologi

k. Mendidik generasi muda agar menjadi warga Negara nasional dan warga dunia

l. Mengajarkan keterampilan pokok, misalnya membaca, menulis, dan berhitung

m. Memberikan keterampilan dan berhubungan dengan mata pencaharian (Abdullah Idi,1999:62-63).

Banyak lagi aspek lain aspek-aspek lain yang turut memeberikan pengaruh mengenai apa yang harus dimasukkan kedalam kurikulum, yakni menjadi kebutuhan masyarakat (the need of society), antara lain: 
a. Interaksi yang komplek antara kekuatan-kekuatan social, politik, ekonomi, militer, industry, cultural dalam masyarakat

b. Kekuatan-kekuatan sebagaimana diungkapkan diatas yang dominan dibagian dunia lainnya yang erat hubungannya dengan Negara bersangkutan

c. Pribadi pemimpin dan tokoh-tokoh yang memegang kekuasaan formal dan informal diberbagai lapisan masyarakat (Abdullah Idi,1999: 63).

Berkaitan dengan hal-hal diatas maka para pengembang (developers) kurikulum, memiliki tugas-tugas atau tanggung jawab untuk:

a. Mempelajari dan memahami kebutuhan masyarakat sebagaimana dirumuskan dalam undang-undang, peraturan, keputusan pemerintah, dan lain-lain

b. Menganalisis masyarakat dimana sekolah berada

c. Menganalisis syarat dan tuntutan terhadap tenaga kerja

d. Menginterpretasi kebutuhan individu dalam ruang lingkup kepentingan masyarakat (Abdullah Idi,1999: 63).

Dalam mengambil suatu keputusan mengenai kurikulum, para pengembang mesti merujuk pada lingkungan atau dunia dimana mereka tinggal, merespon terhadap berbagai kebutuhan yang dilontarkan atau diusulkan oleh beragam golongan dlam masyarakat (sebagaimana telah diungkapkan diatas) dan pemahaman atas tuntutan pencantuman nilainilai falsafah pendidikan bangsa dan berkaitan dengan falsafah pendidikan yang berlaku.

Kadangkala para pengembang kurikulum (curriculum developsers) akan mengahadapi bermacam kendala, antara lain ketentuan-ketentuan pemerintah yang hingga pada taraf tertentu atas membatasi keputusan yang diambilnya. Barangkali tantangan-tantangan yang dihadapi developers akan beragam menurut tingkat kesukaran dan jenjang pendidikan yang ada. Tentu saja, tingkat universitas, akademisi, institut) tidak serumit atau sekompleks dalam merumuskan dan mengembangkan kurikulum untuk tingkat sekolah dasar (SD/MI) dan sekolah menengah (SMP/MTs, SMA/MA) (Abdullah Idi,1999: 63-64).

Meskipun demikian prinsip dasar dalam pengembangan itu sendiri tetap diberlakukan sama. Misalnya perlunya pemahaman filosofis bangsa, filosofis pendidikan, kebutuhan masyarakat, dan lain-lain. Kebutuhan masyarakat perlu di tampung untuk dianalisa, diseleksi dan diambil suatu keputusan. 


\section{Asas Psikologis}

Abdullah Idi (1999: 64) memaparkan kontribusi psikologi terhadap studi kurikulum memiliki dua hal. Pertama, model konseptual dan informasi akan membantu perencanaan pendidikan. Kedua, berisikan metodologi-metodologi yang dapat diadaptasikan untuk penelitian pendidikan.

Dalam menciptakan hasil belajar yang efisien, tentunya asas psikologi perlu diperhatikan dalam proses belajar mengajar dalam kelas ataupun diluar kelas. Pada asas psikologis ini ada 2 (dua) bentuk psikologi yang perlu diperhatikan, yaitu:

a. Psikologi Anak

S.Nasution (1995:12) menyatakan karena sekolah didirikan untuk anak, maka sudah sewajarnya diciptakan suasana dimana anak dapat mengembangkan bakat yang dimilikinya agar mereka dapat berkembang dengan baik

Dalam psikologi anak iniada beberapa hal yang perlu diperhatikan dalam pengembangan kurikulum diantaranya:

1. Anak bukan miniatur orang dewasa

2. Fungsi sekolah di antaranya mengembangkan pribadi anak seutuhnya

3. Faktor anak harus benar-benar diperhatikan dalam pengembangan kurikulum

4. Anak harus menjadi pusat pendidikan/sebagai subjek belajar dan bukan objek belajar

5. Tiap anak unik, mempunyai ciri-ciri tersendiri, lain dari yang lain. Kurikulum hendaknya mempertimbangkan keunikan anak agar ia sedapat mungkin berkembang sesuai dengan bakatnya

6. Walaupun tiap anak berbeda dari yang lain, banyak pula persamaan di antara mereka. Maka sebagian dari kurikulum dapat sama bagi semua (Toni Purwakarta,2009)

b. Psikologi Belajar

Pendidikan di sekolah diberikan dengan kepercayaan dan keyakinan bahwa anak-anak dapat dididik, dapat dipengaruhi kelakuannya. Anakanak dapat belajar, dapat menguasai sejumlah pengetahuan, dapat mengubah sikapnya, dapat menerima norma-norma, dapat menguasai sejumlah keterampilan (S.Nasution, 1995:12).

Pentingnya penguasaan psikologi belajar dalam pengembangan kurikulum antara lain diperlukan dalam hal:

a. Seleksi dan organisasi bahan pelajaran 
b. Menentukan kegiatan belajar mengajar yang paling serasi

c. Merencanakan kondisi belajar yang optimal agar tujuan belajar tercapai (Toni Purwakarta, 2009).

\section{Asas Organisatoris}

Asas ini berkenaan dengan masalah, dalam bentuk yang bagaimana bahan pelajaran akan disajikan ?, apakah dalam bentuk mata pelajaran yang terpisah-pisah, ataukah diusahakan adanya hubungan antara pelajaran yang diberikan, misalnya dalam bentuk broad-field atau bidang studi seperti IPA, IPS, Bahasa, dan lain-lain (S.Nasution, 1995:14).

Dalam mengembangkan suatu kurikulum, para pengembang kurikulum hendaknya memperhatikan aspek organisasi kurikulum yang akan dikembangkan.seperti, Separated Subject Curriculum, Correlated Curriculum, Integrated Curriculum, dan lainnya. Dengan kata lain, konsep pengembangan kurikulum ini hendaknya menjadikan asas organisatoris sebagai awal berpijak sebuah pengembangan kurikulum yang akan disesuaikan dengan kebutuhan dunia pendididikan.

\section{Fungsi Kurikulum}

Menurut pendapat para ahli tentang fungsi kurikulum, seperti pendapat Alexander Inglis (Abdullah Idi,1999: 139-142) dalam bukunya Principle of Secondary Education, menyatakan bahwa fungsi kurikulum adalah:

1. Fungsi penyesuaian

Anak didik hidup dalam suatu lingkungan, yang harus mampu menyesuaikan diri terhadap lingkungan tersebut. Lingkungan yang senantiasa bersifat dinamis, maka anak didik diharapkan mampu menyesuaikan diri dengan kondisi yang demikian. Agar mereka dapat menyesuaikan diri berdampingan dengan masyarakat.

2. Fungsi pengintegrasian

Kehidupan anak-anak didik yang hidup berdampingan dengan masyarakat, tentunya harus dapat mengintegrasikan kepribadian mereka dalam rangka pembentukan atau pengintegrasian masyarakat.

3. Fungsi Diferensiasi

Kurikulum hendaknya dapat memberi pelayanan terhadap perbedaanperbedaan perorangan dalam masyarakat. Pada prinsipnya perbedaan (differensiasi) akan mendorong orang berfikir kritis, kreatif, dan akhirnya akan memajukan kemajuan sosial dalam masyarakat. 
4. Fungsi persiapan

Kurikulum berfungsi untuk mempersiapkan anak-anak didik untuk dapat melanjutkan studi anak-anak didik ke jenjang yang lebih tinggi. karena tuntutan zaman yang lebih maju menuntut mereka untuk lebih luas ilmu pengetahuan meraka dan juga wawasan yang mereka miliki.

Selain untuk persiapan ke jenjang yang lebih tinggi, kurikulum hendaknya juga dapat mempersiapkan mereka agar dapat diterima didunia kerja sesuai dengan kemampuan mereka.

5. Fungsi Pemilihan

Sebuah kurikulum hendaknya bersifat luwes dan fleksibel, agar anakanak didik dapat memilih sesuai denghan aapa yang mereka minat. Semakin banyak pilihan semakin terbuka pula peluang bagi mereka untuk mengarahkan potensi merak kepada apa yang mereka inginkan.

6. Fungsi Diagnostik

Fungsi diagnosostik berfungsi sebagai alat evaluasi bagi siswa, agar mereka dapat mengevaluasi atas diri mereka sendiri. Menyadari kelemahan dan kekuatan yang ada pada diri mereka, sehingga dapat memperbaiki dan mengembangkan sendiri sesuai dengan kemapuan yang ada, yang pada akhirnya dapat berekembang secara maksimal di tengah masyarakat.

\section{Jenis-jenis Kurikulum}

Dalam menyusun sangatlah tergantung pada asas oraganisatoris, yakni bentuk penyajian bahan bahan pelajaran yang dikenal juga dengan sebutan jenis-jenis kurikulum atau tipe-tipe kurikulum.

Berikut bebrapa jenis kurikulum yang menulis rangkum dari bebrapa pendapat ahli, diantaranya:

\section{Separated Subject Curriculum}

Bentuk separated subject terdiri dari mata pelajaran-mata pelajaran yang terpisah satu dengan yang lain. Bentuk ini termasuk paling tua dalam sejarah kurikulum. Sejak jaman dahulu orang yunani maupun orang romawi sudah menggunakan bentuk kurikulum semacam ini. Orang yunani mengajarkan disekolah mata pelajaran-mata pelajaran seperti kesusasteraan, matematika, filsafat, dan ilmu pengetahuan. sedangkan orang romawi mengajarkan gramatika, retorika dan logika yang dinamakan sebagai trivium, serta aritmatika, geometri, astronomi dan musik yang dinamakan sebagai quadrivium. Ketujuh mata pelajaran dalama trivium dan quadrivium itu kemudian dikenal dengan the seven Liberal Arts (Lukmanul Hakim, 2008:8). 
Kurikulum ini menyajikan segala bahan pelajaran dalam berbagai macam mata pelajaran (subjects) yang terpisah-pisah satu sama lain, seakan-akan ada batas pemisah antara mata pelajaran yang satu dengan yang lainnya

Kurikulum mata pelajaran dapat menetapkan syarat-syarat minimum yang harus dikuasai anak, sehingga anak didik naik kelas. Biasanya bahan pelajaran textbook merupakan alat dan sumber utama bagi pelajaran (Abdullah Idi,1999: 27).

Separated subject curriculum ini mengandung berbagai hal yang positif didalam praktek pendidikan disekolah yakni:

a. Bahan pelajaran disajikan secara sistematis dan logis

b. Organisasi kurikulum ini sederhana: mudah disusun, mudah di tambah, mudah dikurangi jumlah mata pelajaran yang diperlukan (mudah direorganisir)

c. Penilaian lebih mudah karena biasanya bahan pelajaran ditentukan berdasarkan buku-buku pelajaran tertentu, sehingga dapat diadakan ujian umum atau tes hasil belajar yang seragam (uniform)diseluruh Negara.

d. Kurikulum ini memudahkan guru dalam melaksankaan pelajaran karena bersifat "Subject centered"; guru-guru yang sudah berpengalaman dan menguasai seluruh bahan pelajarannya menjadi rutin setiap tahun hanya mengulang yang sudah pernah dilakukan sebelumnya.

e. Kebanyakan orang berangggapan bahwa sekolah adalah persiapan masuk perguruan tinggi; di perguruan tinggibiasanya organisasi kurikulum sesuai dengan prionsip terpisash-pisah itu. Jadi organisasi kurikulum di sekolah dasar dan menengah dengan begitu sesuai dengan organisasi di perguruan tinggi (B. Suryosubroto:2)

Disamping hal-hal positif, Separated Subject Curriculum ini juga mendapat kritik-kritik sebagai berikut:

a. Mata pelajaran terlepas-lepas satu sama lain, hal ini tidak sesuai dengan kenyataan kehidupan yang sebenarnya.

b. Tidak atau kurang memperhatikan masalah yang dihadapi dalam kehidupan sehari-hari.

c. Dari sudut psychologis kurikulum demikian mengandung kelemahan; banyak terjadi verbalitas dan menghafal serta makna tujuan pelajaran kurang dihayati oleh anak didik.

d. Kurikulum ini cenderung statis dan ketinggalan dari perkembnagan zaman (B. Suryosubroto:3). 


\section{Correlated Curriculum}

Correlated Curriculum merupakan bentuk organisasi yang menghubungkan antara satu mata pelajaran dengan mata pelajaran lain.hubungan ini dapat dilakukan baik secara sewaktu-waktu ataupun secara diupayakan. Pada cara yang pertama, hubungan antara mata pelajaran-mata pelajaran terjadi secara kebetulan. Jika suatu materi pembelajaran mempunyai pertalian dengan pelajaran lain. Sebagai contoh dalam pelajaran sejarah, kalau kebetulan materi pembelajaran yang diajarkan mempunyai hubungan dengan geografi. Dilakukan korelasi. Demikian pula sebaliknya. Cara kedua, hubungan dilakukan dengan cara membahas satu pokok permasalan dengan dipelajari dalam berbagai mata pelajaran (Lukmanul Hakim, 2008:10).

Pada dasarnya organisasi kurikulum ini menghendaki agar mata pelajaran itu satu sama lainnya ada hubungan, bersangkut paut (correlated) walaupun mungkin batas-batas yang satu dengan yang lain masih di pertahankan.

Prinsip berhubungan (B. Suryosubroto:3) satu sama lain (korelasi) ini dapat dilaksanakan dengan beberapa cara:

a. Antara dua mata pelajaran diadakan hubungan secara tiba-tiba (insidental).

b. Mempertimbangkan masalah-masalah tertentu dalam berbagai macam pelajaran (etis).

c. Mempersatukan beberapa mata pelajaran dengan nmenghilangkan batas-batas masing-masing (sistematis).

Beberapa manfaat (B. Suryosubroto:4) Correlated Curriculum dapat disebutkan antara lain:

a. Dengan korelasi pengetahuan murid lebih integral, tidak terlepaslepas (berpadu)

b. Dengan melihat hubungan erat antara mata pelajaran satu dengan yang lain, minat murid bertambah

c. Korelasi memberikan pengertian yang lebih luas dan mendalam karena memandang dari berbagai sudut.

d. Dengan korelasi maka yang diutamakan adalah pengertian dan prinsip-pinsip bukan bukan pengetahuan akan fakta, dengan begitu lebih memungkinkan penggunaan pengetahuan secara fungsional bagi murid-murid

Adapun disamping kebaikan yang ada tersebut, ada keberatan yang diajukan dalam Correlated Curriculum ini, yakni: 
a. Sulit untuk menghubungkan dengan masalah-masalah yang hangat dalam kehidupan sehari-hari. sebab dasarnya Subject Centered.

b. Broad Fields tidak memberikan pengetahuan yang sistematis dan mendalam untuk sesuatu mata pelajaran sehingga hal ini dipandang kurang cukup untuk bekal mengikuti pelajaran di perguruan tinggi (B. Suryosubroto:4).

\section{Broad Fields Curriculum}

Merupakan bentuk organisasi kurikulum yang dibuat dengan melebur mata pelajaran-mata pelajaran sejenis ke dalam satu pelajaran. Batas-batas antara mata pelajaran itu menjadi kabur. Bahkan jenis mata pelajaran peleburan mempunyai nama yang lain dari nama mata pelajaran asalnya. kita mengenal lima macam broad field dalam kurikulum:

1) Ilmu pengetahuan Sosial (Social Studies), peleburan dari mata Pelajaran-mata pelajaran ilmu bumi, sejarah, hokum, kewarganegaraan, ekonomi, dan sejenis

2) Bahasa (Language Arts), peleburan dari mata pelajaran-mata pelajaran membaca, tata bahasa, menulis, mengarang, menyimak, pengetahuan bahasa

3) Ilmu Pengetahuan Alam (Natural Sciences), peleburan dari ilmu alam, ilmu hayat/ilmu bumi, ilmu kimia, ilmu kesehatan

4) Matematika, peleburan dari berhitung, aljabar, ilmu ukur sudut, bidang dan ruang, serta statistika

5) Kesenian, peleburan dari seni tari, seni suara, seni lukis, seni pahat, dan seni drama (Lukmanul Hakim, 2008:10).

Oranisasi kurikulum Broad Fields ini mempunyai beberapa keuntungan, yaitu:

a) Korelasi memajukan integrasi pengetahuan pada siswa

b) Minat siswa bertambah apabila ia melihat hubungan antara mata pelajaran-mata pelajaran

c) Pengetahuan siswa tentang sewsuatu hal lebih mendalam, jika didapat penjelasan dari berbagai mata pelajaran.

d) Korelasi memberikan pengertian lebih luas karena diperoleh pandangan dari berbagai sudut

e) Korelasi memungkinkan siswa menggunakan pengetahuan dari berbagai mata pelajaran guna memecah masalah

f) Korelasi antara mata pelajaran lebih mengutamakan pengertian dan prinsip-prinsip daripada pengetahuan dan fakta-fakta (Lukmanul Hakim, 2008:10-11). 
Disamping keunggulan organisasi kurikulum ini, ada beberapa kelemahan organisasi kurikulum ini, yaitu:

1) Tidak memberikan pengetahuan yang sistemnatis dan mendalam mengenai berbagai mata pelajaran, akibat luasnya ruang lingkup mata pelajaran itu.

2) Mata pelakaran-mata pelajaran itu tidak disesuaikan dengan kebutuhan dan masalah kehidupan yang dihadapi sehari-hari (Lukmanul Hakim, 2008:11).

\section{Integrated Curriculum}

Kurikulum ini meniadakan batas-batas antara berbagai mata pelajaran dan menyajikan bahan pelajaran dalam bentuk unit atau keseluruhan. Dengan kebulatan bahan pelajaran diharapkan mampu membentuk kepribadian murid yang integral, selaras dengan kehidupan sekitarnya (B. Suryosubroto:4).

Integrated curriculum dilaksanakan melalui pengajaran unit. Suatu unit mempunyai tujuan yang bermakna bagi anak yang biasanya dituangkan dalam bentuk masalah. Untuk memecahkan masalah-masalah itu anak-anak melakukan serangkaian kegiatan saling berkaitan, menghadapkan anaka kepada masalah berarti merangsangnya untuk berfikir dan ia merasa tidak akan merasa puas dan tenang sebelum memecahkan masalah. (S.Nasution, 1995:196)

Dalam pelajaran unit dengan sengaja anak-anak dididik untuk berfikir secara ilmiah menurut langkah-langkah yang disebut Dewey "the method of intelligence"

1) Seorang berfikir bila ia mengahadapi masalah. Masalah itu harus dirumuskan setajam-tajamnya dan sering pula menganalisanya dalam sub-masalah

2) Ia memikirkan hipotesis-hipotesis, yaitu cara-cara yang mungkin memberi jawaban atau penyelesaian masalah itu.

3) Untuk membuktikan benar atau tidaknya suatu hipotesis itu ia harus mengumpulkan keterangan atau data sebanyak-banyaknya.

4) Dengan keterangan-keterangan yang diperoleh itu ia menguji kebenaran hipotesis-hipotesis.

5) Jika diperoleh jawaban berdasarkan pemikiran yang dibenarkan oleh bukti-bukti yang factual, maka kesempatan itu dapat dijadikan pegangan bagi perbuatan atau tindakan kita. Maka kita bertindak secara rasional (S.Nasution, 1995:196-197). 
Berikut beberapa manfaat kurikulum yang "integrated" ini dapat disebutkan sebagai berikut:

a. Segala sesuatu yang dipelajari anak merupakan unit yang bertalian erat, bukan fakta yang terlepas satu sama lainnya.

b. Kurikulum ini sesuai dengan pendapat-pendapat modern tentang belajar, murid dihadapkan kepada maslah yang berarti dsalam kehidupan mereka.

c. Kurikulum ini memungkinkan hubungan yang erat anatara sekolah dengan masyarakat

d. Aktifitas anak-anakmeningkat karena diransang untuk berfikir sendiri dan bekerja sendiri, ataubekerja sama dengan kelompok

e. Kurikulum ini mudah disesuaikan dengan minat, dan kesanggupan dan kematangan murid (B. Suryosubroto:4).

Sebagaimana kurikulum dua terdahulu, integrated Curriculum ini juga mempunyai beberapa kelemahan, diantaranya:

a. Guru-guru kita belum disiapkan untuk mlaksanakan kurikulum ini

b. Kurikulum ini tidak mempunyai organisasi yang sistematis

c. Kurikulum ini memberatkan tugas Guru

d. Kurikulum ini tidak memungkinkan ujian umum, sebab tidak ada uniformitas disekolah-sekolah satu sama lain.

e. Anak-anak diragukan untuk bisa diajak menetukan kurikulum

f. Pada umumnya kondisi sekolah masih kekurangan alat-alat untuk melaksanakan kurikulum ini. (B. Suryosubroto:5)

\section{E. Implementasi Kurikulum untuk anak berkebutuhan khusus 1. Konsep Dasar Implementasi Kurikulum}

Secara sederhana implementasi bisa diartikan pelaksanaan atau penerapan. Esensinya implementasi adalah suatu proses, suatu aktivitas yang digunakan untuk mentransferkan ide/gagasan, program, atau harapan-harapan yang dituangkan dalam bentuk kurikulum disain (tertulis) agar dilaksanakan sesuai dengan disain tersebut (Syafruddin Nurdin, 2005: 73)

Dalam implementasi kurikulum (Syafruddin Nurdin, 2005: 73) ada beberapa pendekatan yang perlu diperhatikan, diantaranya:

a. Mengambarkan implementasi itu dilakukan sebelum penyebaran (desiminasi) kurikulum disain.

Kata proses dalam pendekatan ini adalah aktivitas yang berkaitan dengan penjelasan tujuan program, mendeskripsikan sumber-sumber baru, dan mendemonstrasikan metode pengajaran yang digunakan 
b. Menekankan pada fase penyempurnaan.

Pengembang melakukan pemeriksaaan pada program baru yang direncanakan, sumber-sumber baru, memasukkan isi/materi baru ke program yang sudah ada berdasarkan hasil uji-coba dilapangan dan pengalaman-pengalaman guru

c. Memandang implementasi sebagai bagian dari program kurikulum

Proses implementasi dilakukan dengan mengikuti perkembangan dan mengadopsi program-program yang sudah direncanakan dan sudah diorganisasikan dalam bentuk kurikulum disain (dokumentasi).

Dari ketiga pendekatan diatas dapat disimpulkan bahwa implementasi kurikulum adalah proses aktualisasi kurikulum potensial atau ideal menjadi kurikulum aktual oleh staf pengajar dalam belajar mengajar.

Dalam implementasi pengembangan kurikulum, maka pengembangan kurikulum dapat dilaksanakan terhadap empat komponen kurikulum seperti; Tujuan, Isi/materi, proses, dan evaluasi.

Tujuan ialah seperangkat kemampuan atau kompetensi yang akan dicapai setelah para siswa menyelesaikan program pendidikan dalam kurun waktu tertentu. Secara sederhana tujuan pembelejaran yang akan menjadi fokus ialah; 1) Standar Kompetensi Lulusan, 2) Standar Kompetensi, 3) Kompetensi Dasar, dan 4) Indikator Keberhasilan.

Sementara isi atau materi adalah isi atau konten yang harus dipelajari oleh siswa supaya bisa mencapai tujuan yang telah ditetapkan. Materi pembelajaran biasanya dikembangkan oleh guru dengan tetap mengacu kepada SKL, SK, KD, dan Indikator.

Berbeda dengan isi atau materi, proses ialah kegiatan atau aktifitas yang akan dijalani oleh siswa supaya bisa menguasai materi yang diajarkan dan bisa mencapai tujuan-tujuan pembelajaran yang telah ditetapkan. Adapun proses pembelajaran berhubungan dengan penggunaan metode yang tetap, media, strategi, sumber, dan lainnya.

Evaluasi merupakan proses yang dilakukan untuk mengetahui tingkat keberhasilan pencapaian tujuan-tujuan pendidikan yang telah ditetapkan. Evaluasi berupa pemberian latihan-latihan, tugas dirumah, ujian lisan maupun tulisan, hingga portofolio karya siswa.

\section{Prinsip pengembangan kurikulum anak berkebutuhan khusus}

Sebelum melakukan pengembangan kurikulum untuk siswa berkebutuhan khusus, perlu memperhatikan beberapa prinsip (Budiyanto, 2013:83) yang akan dijadikan acuan oleh para guru, antara lain;. 
a. Kurikulum umum yang diberlakukan untuk siswa reguler perlu dirubah (dimodifikasi) untuk disesuaikan dengan kondisi siswa berkebutuhan khusus.

b. Penyesuaian kurikulum dengan kemampuan siswa berkebutuhan khusus bisa terjadi pada komponen tujuan, materi, proses, dan atau evaluasi

c. Penyesuaian kurikulum tidak harus sama pada masing-masing komponen. Artinya jika komponen harus dimodifikasi, mungkin tidak demikian halnya dengan proses. Dst

d. Proses penyesuaian juga tidak harus sama dengan semua materi. Untuk materi tertentu perlu dimodifikasi, tetapi mungkin tidak perlu untuk materi yang lain.

e. Proses modifikasi juga tidak harus sama untuk semua pelajaran. Untuk mata pelajaran tertentu mungkin perlu banyak modifikasi tetapi tidak perlu untuk materi yang lain.

f. Proses modifikasi juga tidak sama pada masing-masing jenis kelainan. Siswa berkebutuhan khusus yang tidak mengalami hambatan kecerdasan (tunanetra, tunrungu, tundaksa) mungkin akan sedikit membutuhkan modifikasi kurikulum. Sedangkan siswa yang mengalami hambatan kecerdasan (tungrahita) membutuhkan modifikasi hampir pada semua komponen pembelajaran (tujuan, materi, proses, dan evaluasi)

\section{Model pengembangan kurikulum anak berkebutuhan khusus}

Berbicara tentang implementasi kurikulum pendidikan inklusif, ada empat model (Budiyanto, 2013:80-83) yang ditawarkan;

a. Model Duplikasi

Duplikasi berarti meniru atau mengandakan. Dalam model kurikulum duplikasi, kurikulum yang dipelajari oleh anak berkebutuahan khusus sama persis dengan apa yang diapatkan oleh anak reguler, mulai dari tujuan pembelajaran, isi atau materi, proses hingga evaluasi. Kesemuanya diduplikasi untuk dipelajarai oleh anak berkebutuhan khusus.

Duplikasi tujuan ialah berarti tujuan pembelajaran yang digunakan sesuai standar nasional digunakan juga oleh anak berkebutuhan khusus, mulai dari SKL yang sama, SK, KD, hingga Indikator keberhasilan. Begitu juga dengan duplikasi isi atau materi yang diajarkan kepada anak normal dari materi pokok, sub-sub materi hingga jabaran materi juga dipelajari oleh anak berkebutuhan khusus. Untuk duplikasi proses berarti anak berkebutuhan khusus mendapatkan perlakuan yang sama di kelas, media yang sama, waktu belajar dan kondisi lainnya. Kemudian duplikasi evaluasi 
juga tidak jauh berbeda dengan anak reguler lainnya, mulai dari bentuk soal, butir-butir soal, lokasi ujian, alokasi waktu dan lainnya.

b. Model Modifikasi

Modifikasi berarti merubah untuk disesuaikan. Dalam artian kurikulum yang dipakai oleh siswa reguler dirubah untuk disesuaikan dengan kemampuan anak siswa berkebutuhan khusus. Modifikasi kurikulum bisa dilakukan kepada empat komponen kurikulum, tergantung kemampuan peserta didik berkebutuhan khusus.

Jika dilakukan modifikasi pada tujuan berarti kompetensi yang diajarkan kepada siswa reguler akan di modifikasi sedemikian rupa, sehingga siswa berkebutuhan khusus akan memiliki rumusan kompetensi yang akan berbeda dengan siswa reguler. Hal ini bisa dimodifikasi pada SKL, SK, KD,atau indikator.

Begitupun pada komponen isi atau materi, jika dilakukan modifikasi maka materi-materi yang dianggap memberatkan anak berkebutuhan khusus dirubah untuk disederhanakan sehingga sesuai dengan kemampuannya. Artinya cakupan dari materi mulai dari keluasan, kedalaman, dan kemampuan yang sebelumnya sulit menjadi lebih rendah dari pada yang didapatkan siswa reguler.

Melakukan modifikasi proses bisa dilakukan dengan merubah setting kelas, alokasi waktu, metode penyampaian guru, media yang digunakan agar materi dapat diserap dengan mudah oleh siswa. Begitu pula dengan modifikasi evaluasi dapat dirubah berupa bentuk instrumen, kriteria kelulusan, sistem kenaikan kelas, bentuk rafor, ijazah dan lainnya.dalam arti kata anak berkebutuhan khusus menjalani evaluasi yang berbeda dengan siswa reguler.

c. Model Subtitusi

Susbtitusi berarti mengganti. Dalam kaitan dengan model kurikulum subtitusi berarti mengganti sesuatu yang ada dalam kurikulum umum dengan sesuatu yang lain. Perubahan yang dilakukan disebabkan karena tidak mungkin diberlakukan kepada anak berkebutuhan khusus, tetapi masih bisa dengan hal lain yang kurang lebih sepadan (memiliki nilai yang kurang lebih sama). Model penggantian (subtitusi) bisa terjadi dalm hal pembelajaran, materi, proses atau evaluasi.

\section{d. Model Omisi}

Omisi artinya menghilangkan. Dalam kaitannya dengan model kurikulum, brarti menghilangkan sesuatu (bagian atau keseluruhan) dari kurikulum umum, karena hal tersebut tidak mungkin diberikan kepada 
anak berkebutuhan khusus. Dengan kata lain, omisi beberati sesuatu yang ada dalam kurikulum umum tidak disampaikan atau tidak diberikan kepada siswa berkebutuhan khusus karena sifatnya terlalu sulit atau tidak sesuai dengan kondisi anak berkebutuhan khusus. Bedanya dengan subtitusi adalah jika dalam subtitusi ada materi pengganti yang sepadan, sedangkan dalam model omisis tidak ada materi pengganti.

\section{Penerapan kurikulum anak berkebutuhan khusus}

Dalam melakukan penerapan model kurikulum tersebut, mari kita lihat beberapa model implementasi kurikulum untuk anak berkebutuhan khusus pada sekolah inklusif. Seperti yang tergambar dari skema berikut: (Budiyanto, 2013:84)

Gambar 7.1 Skema Implementasi model kurikulum

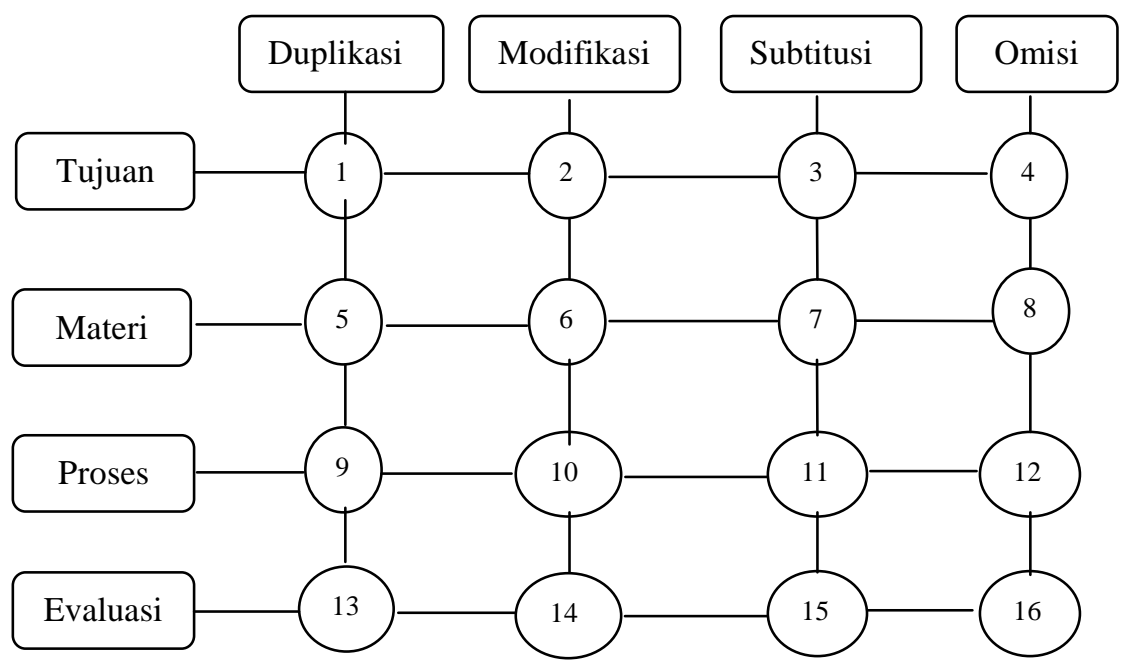

Dari gambar diatas berbagai ada 16 (enam belas) kemungkinan model kurikulum yang dapat diterapkan antuk pembelajaran anak berkebutuhan khusus di sekolah inklusif, seperti; 4 skema model untuk tujuan $(1,2,3,4)$, begitu juga dengan materi $(5,6,7,8)$, untuk proses juga bisa dengan $(9,10,11,12)$, dan $(13,14,15,16)$ untuk model evaluasi.

Jadi penerapan model ini tidak serta merta dapat dipilih sesuka hati guru saja, akan tetapi pemilihan model pengembangan dengan menggunakan duplikasi, modifikasi, subtitusi, ataupun omisi, tergantung dari kondisi peserta didik. Apakh menggunakan duplikasi pada tujuan, atau materi itu tergantung dari hasil dari identifikasi dan asesmen terhadap kemampuan akademik peserta didik.

Secara garis besar kurikulum untuk anak khusus memiliki dua kategori; 1) Kurikulum untuk anak berkebutuhan khusus namun tidak 
memiliki hambatan kecerdasan, dan 2) Kurikulum untuk anak berkebutuhan khusus dan memiliki hambatan kecerdasan. Anak yang tidak memiliki hambatan kecerdasan, seperti anak yang tunanetra, tunarungu, tunadaksa, dan lainnya. Tidak membutuhkan modifikasi kurikulum secara menyeluruh, akan tetapi menyesuaikan dengan kondisi fisik dari peserta didik tersebut. Sementara anak yang mengalami hambatan kecerdasan adalah anak-anak yang mengalami tungrahita sangat membutuhkan modifikasi kurikulum pada empat komponen yang telah disebutkan di atas. Hal tersebut dikarenakan oleh kemampuan dari peserta didik yang mengalami hambatan kecerdasan memerlukan penyesuian materi sedemikian rupa hingga dapat ditangkap dengan baik. Dibawah ini merupakan beberapa penerapan modifikasi kurikulum dengan empat komponennya;

a) Modifikasi Tujuan.

Sebagaimana diketahui ada empat tujuan pembelajaran yang dapat dimodifikasi sedemikian rupa agar pembelajaran sesuai dengan kebutuhan peserta didik, diantaranya; SKL, SK, KD, dan Indikator. Namun sebagai bahan pertimbangan untuk modifikasi tujuan lebih kepada modifikasi KD dan indikator saja. Karena pada standar kompetensi lulusan dan standar kompetensi hanya bersifat umum sehingga sementara kompetensi dasar lebih spesifik. (lihat Tabel 1 dan

Tabel 7.1. Model kurikulum anak yang tidak mengalami gangguan kecerdasan

\begin{tabular}{|l|c|c|c|c|c|c|c|c|c|}
\hline & \multicolumn{3}{|c|}{ TUJUAN } & \multirow{2}{*}{ MATERI } & \multicolumn{2}{c|}{ PROSES } & \multicolumn{3}{c|}{ EVALUASI } \\
\cline { 2 - 9 } & SK & KD & INDIKATOR & & METODE & MEDIA & SOAL & CARA & ALAT \\
\hline Duplikasi & $\checkmark$ & $\checkmark$ & $\checkmark$ & $\checkmark$ & $\checkmark$ & $\checkmark$ & $\checkmark$ & $\checkmark$ & $\checkmark$ \\
\hline Modifikasi & $\times$ & $\times$ & $\times$ & $\times$ & $\checkmark$ & $\checkmark$ & $\times$ & $\checkmark$ & $\checkmark$ \\
\hline Subtitusi & $\times$ & $\times$ & $\times$ & $\times$ & $\times$ & $\times$ & $\times$ & $\times$ & $\times$ \\
\hline Omisi & $\times$ & $\times$ & $\times$ & $\times$ & $\times$ & $\times$ & $\times$ & $\times$ & $\times$ \\
\hline
\end{tabular}

Tabel 7.2. Model kurikulum anak yang mengalami gangguan kecerdasan

\begin{tabular}{|c|c|c|c|c|c|c|c|c|c|}
\hline & \multicolumn{3}{|c|}{ TUJUAN } & \multirow{2}{*}{ MATERI } & \multicolumn{3}{c|}{ PROSES } & \multicolumn{3}{c|}{ EVALUASI } \\
\cline { 2 - 10 } & SK & KD & INDIKATOR & & METODE & MEDIA & SOAL & CARA & ALAT \\
\hline Duplikasi & $\checkmark$ & $\times$ & $\times$ & $\times$ & $\times$ & $\times$ & $\times$ & $\times$ & $\times$ \\
\hline
\end{tabular}




\begin{tabular}{|l|c|c|c|c|c|c|c|c|c|}
\hline Modifikasi & $\times$ & $\checkmark$ & $\checkmark$ & $\checkmark$ & $\checkmark$ & $\checkmark$ & $\checkmark$ & $\checkmark$ & $\checkmark$ \\
\hline Subtitusi & $\times$ & $\checkmark$ & $\checkmark$ & $\checkmark$ & $\checkmark$ & $\checkmark$ & $\checkmark$ & $\checkmark$ & $\checkmark$ \\
\hline Omisi & $\times$ & $\checkmark$ & $\checkmark$ & $\checkmark$ & $\checkmark$ & $\checkmark$ & $\checkmark$ & $\checkmark$ & $\checkmark$ \\
\hline
\end{tabular}

Dari dua tabel diatas terlihat bahwa model kurikulum untuk anak berkebutuhan khusus yang tidak mengalami hambatan kecerdasan hanya membutuhkan modifikasi pada proses pembelajaran saja, seperti anak yang mengalami tunanetra membutuhkan modifikasi pada media yang dapat didengar atau dengan tulisan braile, begitu juga dengan cara penyajian soal. Sementara untuk anak berkebutuhan khusus yang mengalami hambatan kecerdasan memerlukan modifikasi pada hampir semua bagian.

Tabel 7.3. Contoh Modifikasi Kompetensi Dasar (KD)

Mata Pelajaran : Pendidikan Agama Islam

Kelas : IV (empat)

\begin{tabular}{|c|c|c|c|}
\hline \multirow{2}{*}{$\begin{array}{c}\text { Standar } \\
\text { Kompetensi } \\
\text { (Umum) }\end{array}$} & \multirow{2}{*}{$\begin{array}{l}\text { Kompetensi } \\
\text { Dasar } \\
\text { (Umum) }\end{array}$} & \multicolumn{2}{|c|}{$\begin{array}{c}\text { Kompetensi Dasar (KD) } \\
\text { (Modifikasi) }\end{array}$} \\
\hline & & $\begin{array}{l}\text { Berkebutuhan } \\
\text { Khusus Ringan }\end{array}$ & $\begin{array}{l}\text { Berekebutuhan } \\
\text { Khusus Sedang }\end{array}$ \\
\hline $\begin{array}{l}\text { Menceritakan } \\
\text { kisah Nabi }\end{array}$ & $\begin{array}{l}\text { Menceritakan } \\
\text { kisah Nabi } \\
\text { Muhammad saw }\end{array}$ & $\begin{array}{l}\text { Menceritakan } \\
\text { kisah } \\
\text { pengangkatan } \\
\text { nabi } \\
\text { Muhammad saw } \\
\text { menjadi Rasul }\end{array}$ & $\begin{array}{l}\text { Menceritakan } \\
\text { tentang perilaku } \\
\text { nabi Muhammad } \\
\text { saw }\end{array}$ \\
\hline
\end{tabular}

Tabel 7.4. Contoh Modifikasi Indikator

Mata Pelajaran : Pendidikan Agama Islam

Kelas

: IV (empat)

\begin{tabular}{|c|c|c|c|c|}
\hline \multirow{2}{*}{$\begin{array}{c}\text { Standar } \\
\text { Kompetensi } \\
\text { (Umum) }\end{array}$} & \multirow{2}{*}{$\begin{array}{c}\text { Kompetensi } \\
\text { Dasar } \\
\text { (Umum) }\end{array}$} & \multirow{2}{*}{$\begin{array}{l}\text { Indikator } \\
\text { (Umum) }\end{array}$} & \multicolumn{2}{|c|}{$\begin{array}{c}\text { Indikator } \\
\text { (Modifikasi) }\end{array}$} \\
\hline & & & $\begin{array}{l}\text { Hambatan } \\
\text { Kecerdasan } \\
\text { Ringan }\end{array}$ & $\begin{array}{l}\text { Hambatan } \\
\text { Kecerdasan } \\
\text { Sedang }\end{array}$ \\
\hline $\begin{array}{l}\text { Menceritakan } \\
\text { kisah Nabi }\end{array}$ & $\begin{array}{l}\text { Menceritakan } \\
\text { kisah Nabi } \\
\text { Muhammad } \\
\text { saw }\end{array}$ & $\begin{array}{l}\text { Menjelaskan } \\
\text { peristiwa } \\
\text { sebelum } \\
\text { nabi lahir }\end{array}$ & $\begin{array}{l}\text { Menceritakan } \\
\text { tentang sosok } \\
\text { orang tua } \\
\text { nabi } \\
\text { Muhammad } \\
\text { saw }\end{array}$ & $\begin{array}{l}\text { Menceritakan } \\
\text { tentang tanda- } \\
\text { tanda } \\
\text { kelahiran nabi } \\
\text { Muhammad } \\
\text { saw }\end{array}$ \\
\hline
\end{tabular}


b) Modifikasi Isi/ Materi

Modifikasi Isi atau materi yang merupakan suatu bagian yang akan dipelajari untuk mencapai indikator keberhasilan. Dalam melakukan modifikasi materi tidak mesti semua materi dimodifikasi, hanya materi-materi yang dianggap menyulitkan anak berkebutuhan khusus, modifikasi materi ini bertujuan agar siswa berkebutuhan khusus dapat menyerap pokok-pokok pembelajaran sesuai dengan kemampuannya.

Tabel 7.5. Contoh Modifikasi Materi pembelajaran

Mata Pelajaran : Pendidikan Agama Islam

Kelas : IV (empat)

\begin{tabular}{|c|c|c|c|c|}
\hline \multirow{2}{*}{$\begin{array}{c}\text { Kompetensi } \\
\text { Dasar } \\
\text { (Umum) }\end{array}$} & \multirow{2}{*}{$\begin{array}{l}\text { Materi } \\
\text { Pelajaran } \\
\text { (Umum) }\end{array}$} & \multirow{2}{*}{$\begin{array}{l}\text { Kompetensi } \\
\text { Dasar (KD) } \\
\text { (Modifikasi) }\end{array}$} & \multicolumn{2}{|c|}{$\begin{array}{c}\text { Materi Pelajaran } \\
\text { (Modifikasi) }\end{array}$} \\
\hline & & & $\begin{array}{c}\text { Hambatan } \\
\text { Kecerdasan } \\
\text { Ringan }\end{array}$ & $\begin{array}{c}\text { Hambatan } \\
\text { Kecerdasan } \\
\text { Sedang }\end{array}$ \\
\hline $\begin{array}{l}\text { Menceritakan } \\
\text { kisah Nabi } \\
\text { Muhammad } \\
\text { saw }\end{array}$ & $\begin{array}{l}\text { Kisah Nabi } \\
\text { Muhammad } \\
\text { saw }\end{array}$ & $\begin{array}{l}\text { Menceritakan } \\
\text { kisah } \\
\text { kelahiran } \\
\text { nabi } \\
\text { Muhammad } \\
\text { saw l }\end{array}$ & $\begin{array}{l}\text { Kisah orang } \\
\text { tua nabi } \\
\text { Muhammad } \\
\text { saw }\end{array}$ & $\begin{array}{l}\text { Tanda-tanda } \\
\text { kelahiran nabi } \\
\text { Muhammad } \\
\text { saw }\end{array}$ \\
\hline
\end{tabular}

c) Modifikasi Proses

Agar materi yang disampaikan dapat diserap oleh siswa, maka perlu dilakukan modifikasi proses pembelajaran, hal ini dilakukan karena siswa berkebutuhan khusus memiliki berbagai hambatan yang nantinya menyulitkan proses itu sendiri jika mengikuti proses seperti siswa reguler, berikut beberapa contoh modifikasi (Budiyanto, 2013:89-90) proses;

Tabel 7.6. Contoh Modifikasi Proses

\begin{tabular}{|l|l|}
\hline \multicolumn{1}{|c|}{ Jenis Hambatan } & \multicolumn{1}{|c|}{ Contoh Modifikasi Proses } \\
\hline Hambatan Penglihatan & $\begin{array}{l}\text { Penyajian lebih menekankan verbal/auditif. } \\
\text { Guru berusaha memverbalkan berbagai }\end{array}$ \\
& informasi atau objek yang ada dilingkungan \\
& - Penggunaan Braille sebagai sarana baca tulis \\
& Penggunaan alat/media pembelajaran yang \\
- Penggunaan alat audio (tape, recorder, dll) \\
- Penggunaan buku bicara, computer bicara \\
dan lain-lain media bicara
\end{tabular}




\begin{tabular}{|c|c|}
\hline & $\begin{array}{l}\text { visual . guru berusaha selalau tatap muka } \\
\text { dengan siswa ketika berbicara } \\
\text { - Penggunaan bahasa isyarat dalam } \\
\text { berkomunikasi } \\
\text { - Penempatan siswa tunarungu pada tempat } \\
\text { duduk di depan supaya mudah bertatap muka } \\
\text { dengan guru } \\
\text { - Penggunaan alat bantu visual }\end{array}$ \\
\hline Hambatan Kecerdasan & $\begin{array}{l}\text { - Penyajian materi dengan penjelasan yang } \\
\text { lebih sederhana } \\
\text { - Penggunaan objek-objek konkrit dalam } \\
\text { penjelasan konsep } \\
\text { - Pemberian materi dan tugas-tugas yang } \\
\text { kadarnya lebih mudah. Pembelajaran } \\
\text { tambahan secara individu } \\
\text { - Penekananan pembelajar pada kompetensi- } \\
\text { kompetensi fungsional (skil yang dibutuhkan } \\
\text { untuk kemandirian dalam aktivitas } \\
\text { kehidupan sehari-hari) }\end{array}$ \\
\hline $\begin{array}{l}\text { Hamabatan Fisik dan } \\
\text { Motorik }\end{array}$ & $\begin{array}{l}\text { Modifikasi berbagai alat, sarana dan lingkungan } \\
\text { yang memungkinkan/ memudahkan mereka } \\
\text { untuk terlibat dala berbagai aktivitas }\end{array}$ \\
\hline $\begin{array}{l}\text { Hambatan Emosi dan } \\
\text { Perilaku }\end{array}$ & $\begin{array}{l}\text { - } \text { Modifikasi perilaku dan emosi melalui } \\
\text { kegiatan kelompok } \\
\text { - Pemberian pembelajaran tambahan } \\
\text { individual } \\
\text { - Penempatan tempat duduk dengan dengan } \\
\text { guru } \\
\text { - Penyaluran bakat pada bidang keahlian } \\
\text { tertentu }\end{array}$ \\
\hline
\end{tabular}

d) Modifikasi Evaluasi

Modifikasi dilakukan menyesuaikan dengan tingkat hambatan yang dialami oleh anak berkebutuhan khusus. Modifikasi dilakukan pada bentuk soal, cara pelaksanaan, kriteria penilaian, dan bentuk rapor anak berkebutuhan khusus. Hal ini akan dibahas pada bab tersendiri dalam buku ini. 


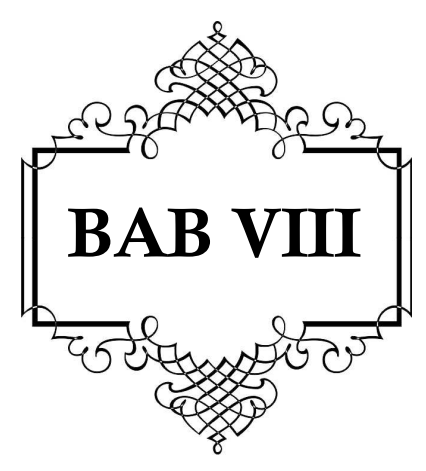

\section{GURU UNTUK ANAK BERKEBUTUHAN KHUSUS}

Setelah membaca bab ini pembaca diharapkan:

* Memahami konsep dasar Guru

* Memahami tugas pokok guru

* Mengetahui kompetensi guru

\section{A. Konsep Dasar Guru}

Di dalam Kamus Besar Bahasa Indonesia (2002:330) dinyatakan bahwa guru adalah orang yang pekerjaannya (mata pencahariannya, profesinya) mengajar.

Terminologi Guru dalam undang undang nomor 14 tahun 2005 (2006:2) tengang Guru dan Dosen dijelaskan bahwa guru adalah pendidik profesional dengan tugas utama mendidik, mengajar, membimbing, mengarahkan, melatih, menilai, dan mengevaluasi peserta didik pada pendidikan anak usia dini jalur pendidikan formal, pendidikan dasar, dan pendidikan menengah.

Menurut Jean D. Grambs dan C. Morris (Hamzah B. Uno, 2010:15) mengatakan bahwa "Teacher are those persons who consciously direct the experiences and behavior of an individual so that education takes places", maksudnya guru adalah mereka yang secara sadar mengarahkan pengalaman dan tingkah laku dari seorang individu hingga dapat terjadi pendidikan

Berdasarkan beberapa kutipan di atas dapat disimpulkan bahwa yang dimaksud dengan guru adalah pendidik profesional dengan tugas 
utama mendidik, mengajar, membimbing, mengarahkan, melatih, menilai, dan mengevaluasi peserta didik pada pendidikan anak usia dini jalur pendidikan formal, pendidikan dasar, dan pendidikan menengah, dengan tujuan untuk mencapai suatu tujuan yang telah ditentukan ditentukan.

\section{B. Tugas Pokok dan Peranan Guru dalam Proses Pembelajaran}

Pada dasarnya ada beberapa tugas yang harus dilaksanakan oleh guru berhubungan dengan profesinya sebagai pengajar. Menurut Peters (Nana Sudjana, 2002:15), ada tiga tugas pokok guru, yaitu:

a) Guru sebagai pengajar

Guru sebagai pengajar lebih menekankan kepada tugas dalam merencanakan dan melaksanakan pengajaran. Dalam tugas ini guru dituntut memiliki seperangkat pengetahuan dan keterampilan teknis mengajar, disamping menguasai ilmu atau bahan yang akan diajarkannya.

b) Guru sebagai pembimbing

Guru sebagai pembimbing memberi tekanan kepada tugas, memberikan bantuan kepada siswa dalam pemecahan masalah yang dihadapinya. Tugas ini merupakan aspek mendidik, sebab tidak hanya berkenaan dengan penyampaian ilmu pengetahuan tetapi juga menyangkut pengembangan kepribadian siswa.

c) Guru sebagai administrator kelas.

Sedangkan tugas sebagai administrator kelas pada hakikatnya merupakan jalinan antara ketatalaksanaan bidang pengajaran dan ketatalaksanaan pada umumnya. Namun demikian, ketatalaksanaan bidang pengajaran lebih menonjol dan lebih diutamakan bagi profesi guru.

Sedangkan menurut Amstrong (Nana Sudjana, 2002:16) membagi tugas pokok dan tanggung jawab guru kepada lima kategori, yaitu:

a) Tanggung jawab dan tugas dalam pengajaran

b) Tanggung jawab dan tugas dalam memberikan bimbingan

c) Tanggung jawab dan tugas dalam mengembangkan kurikulum

d) Tanggung jawab dan tugas dalam mengembangkan profesi

e) Tanggung jawab dan tugas dalam membina hubungan dengan masyarakat.

Menurut Uzer (Hamzah B. Uno,2010:20) ada tiga jenis tugas guru, yaitu: (a) tugas dalam bidang profesi, (b) tugas kemanusiaan, (c) tugas dalam bidang kemasyarakatan. Tugas guru sebagai suatu profesi meliputi mendidik dalam arti meneruskan dan mengembangkan nilai hidup, 
mengajar berarti meneruskan dan mengembangkan iptek, dan melatih berarti mengembangkan keterampilan pada peserta didik. Tugas guru dalam bidang kemanusiaan meliputi guru di sekolah harus dapat menjadi orang tua kedua, dapat memahami peserta didik dengan tugas perkembangannya mulai dari siswa sebagai makhluk bermain, sebagai makhluk remaja/berkarya dan sebagai makhluk dewasa/berpikir.

Menurut Muhammad Ali (2008:4), sekurang-kurangnya ada tiga tugas pokok guru dalam proses belajar mengajar, yaitu:

a. Merencanakan

Perencanaan yang dibuat merupakan antisipasi dan perkiraan tentang apa yang akan dilakukan dalam pengajaran, sehingga tercipta suatu situasi yang memungkinkan terjadinya proses belajar yang dapat mengantarkan siswa mencapai tujuan yang diharapkan. Perencanaan ini meliputi: (1) tujuan yang hendak dicapai, (2) bahan pelajaran yang dapat mengantarkan siswa mencapai tujuan, (3) bagaimana proses belajar mengajar yang akan diciptakan oleh guru agar siswa mencapai tujuan secara efektif dan efesien dan (4) bagaimana menciptakan serta menggunakan alat untuk mengetahui atau mengukur apakah apakah tujuan itu tercapai atau tidak.

b. Melaksanakan pengajaran

Pelaksanaan pengajaran seharusnya berpegang pada apa yang tertuang dalam perencanaan. Namun situasi yang dihadapi guru dalam melakukan pengajaran mempunyai pengaruh besar terhadap proses belajar mengajar itu sendiri. Situasi pengajaran itu banyak dipengaruhi oleh faktor-faktor: (1) faktor guru, (2) faktor siswa, (3) faktor kurikulum dan (4) faktor lingkungan.

c. Memberikan balikan

Balikan mempunyai fungsi untuk membantu siswa memelihara minat dan antusias siswa dalam melaksanakan tugas belajar. Salah satu alasan yang dikemukakan adalah bahwa belajar itu ditandai oleh adanya keberhasilan dan kegagalan. Bila hal ini diketahui oleh siswa, akan membawa dampak berupa hadiah dan hukuman. Keberhasilan berdampak hadiah (reward) dan kegagalan berdampak hukuman (punishment). Suatu hadiah sebagai dampak dari keberhasilan yang dicapai dapat menjadi penguat (reinforcement) terhadap hasil belajar, sedangkan suatu hukuman sebagai dampak dari kegagalan dapat menghilangkan tingkah laku yang tidak diinginkan. Upaya memberikan balikan ini harus dilakukan secara terus menerus, dengan demikian 
minat dan antusias siswa dalam belajar selalu terpelihara. Upaya ini dapat dilakukan dengan jalan melakukan evaluasi.

Uzer (Hamzah B. Uno, 2010:21) mengemukakan bahwa secara khusus tugas guru dalam proses pembelajaran tatap muka adalah:

1. Tugas pengajar sebagai pengelola pembelajaran, meliputi:

a. Tugas manejerial, menyangkut tugas administrasi (memimpin kelas), baik internal maupun eksternal, seperti:
a) berhubungan dengan peserta didik
b) alat perlengkapan kelas (material)
c) tindakan-tindakan professional

b. Tugas edukasional, menyangkut fungsi mendidik yang bersifat:

a) motivasional

b) pendiplisinan

c) sanksi sosial (tindakan hukuman)

c. Tugas instruksional, menyangkut fungsi mengajar yang bersifat:

a) penyampaian meteri

b) pemberian tugas-tugas pada peserta didik

c) mengawasi dan memeriksa tugas

2. Tugas pengajar sebagai pelaksana (executive teacher), meliputi:

a. Menilai kemajuan program pembelajaran

b. Menyediakan kondisi yang memungkinkan peserta didik belajar sambil bekerja (learning by doing)

c. Mengembangkan kemampuan peserta didik dalam menggunakan alat-alat belajar

d. Mengkoordinasi, mengarahkan, dan memaksimalkan kegiatan kelas

e. Mengkomunikasikan semua informasi dari dan/atau ke peserta didik

f. Membuat keputusan instruksional dalam situasi tertentu

g. Bertindak sebagai manusia sumber

h. Membimbing pengalaman peserta didik sehari-hari

i. Mengarahkan peserta didik agar mandiri

j. Mampu memimpin kegiatan belajar yang efektif dan efesien untuk mencapai hasil yang optimal.

Selain mempuyai tugas pokok seperti yang dijelaskan diatas, guru juga mempunyai peranan yang sangat penting dalam proses pembalajaran. Wina Sanjaya (2006:21) berpendapat bahwa ada beberapa peran guru dalam proses pembelajaran, diantaranya: 
1. Guru sebagai sumber belajar

Peran guru sebagai sumber belajar berkaitan erat dengan penguasaan materi pelajaran. Dikatakan guru yang baik manakala ia dapat menguasai materi pelajaran dengan baik, sehingga ia benar-benar berperan sebagai sumber belajar bagi anaknya. Sebagai sumber belajar dalam proses pembalajaran hendaknya guru melakukan hal-hal:

a. Sebaiknya guru memiliki bahan referensi yang lebih banyak dibandingkan dengan siswa

b. Guru dapat menunjukkan sumber belajar yang dapat dipelajari oleh siswa yang biasanya memilki kecepatan belajar di atas rata-rata siswa yang lain. Siswa yang demikian perlu diberikan perlakuan khusus, misalnya dengan memberikan bahan pengayaan dengan menunjukkan sumber belajar yang berkenaan dnagn materi pelajaran.

c. Guru perlu melakukan pemetaan tentang materi pelajaran.

2. Guru sebagai fasilitator

Sebagai fasilitator, guru berperan dalam memberikan pelayanan untuk memudahkan siswa dalam kegiatan proses pembelajaran. Agar dapat melaksanakan peran sebagai fasilitator dalam proses pembelajaran, ada beberapa hal yang harus dipahami guru yang berhubungan dengan pemanfaatan berbagai media dan sumber belajar, diantaranya adalah:

a. Guru perlu memahami berbagai jenis media dan sumber belajar berserta fungsi masing-masing media tersebut.

b. Guru perlu mempunyai keterampilan dalam merancang suatu media.

c. Guru dituntut untuk mampu mengorganisasikan berbagai jenis media serta dapat memanfaatkan berbagai sumber belajar.

d. Guru dituntut agar mempunyai kemampuan dalam berkomunikasi dan berinteraksi dengan siswa.

3. Guru sebagai pengelola

Sebagai pengelola pembelajaran (learning manajer), guru berperan dalam menciptakan iklim belajar yang memungkinkan siswa dapat belajar secara nyaman. Dalam melaksanakan pengelolaan pembelajaran ada dua macam kegiatan yang harus dilakukan, yaitu mengelola sumber belajar dan melaksanakan 
peran sebagai sumber belajar itu sendiri. Sebagai manajer, guru memiliki empat fungsi umum, yaitu;
a. Merencanakan tujuan belajar
b. Mengorganisasikan berbagai sumber belajar untuk mewujudkan tujuan belajar
c. Memimpin, yang meliputi memotivasi, mendorong, dan menstimulasi siswa
d. Mengawasi segala sesuatu, apakah sudah berfungsi sebagaimana mestinya atau belum dalam rangka pencapauan tujuan.

4. Guru sebagai demonstrator

Yang dimaksud dengan peran sebagai demonstrator adalah peran untuk mempertunjukkan kepada siswa segala sesuatu yang dapat membuat siswa lebih mengerti dan memahami setiap pesan yang disampaikan dan guru harus menunjukkan sikap-sikap yang terpuji. Sebagai demonstrator guru harus dapat menunjukkan bagaimana caranya agar setiap materi pelajaran bisa lebih dipahami dan dihayati oleh setiap siswa.

5. Guru sebagai pembimbing

Agar guru berperan sebagai pembimbing yang baik, maka guru harus memiliki beberapa hal, diantaranya:

a. Memiliki pemahaman tentang anak yang dibimbingnya.

b. Memahami dan terampil dalam merencanakan, baik merencanakan tujuan dan kompetensi yang akan dicapai maupun merencanakan proses pembelajaran.

6. Guru sebagai motivator

Untuk memperoleh hasil belajar yang optimal, guru dituntut kratif membangkitkan motivasi belajar siswa, sebab kuat lemahnya atau kuat tidaknya usaha yang dilakukan seseorang mencapai suatu tujuan akan ditentukan oleh kuat lemahnya motif yang dimilikinya. Adapun cara-cara yang dapat dilakukan guru untuk membangkitkan motivasi cara belajar siswa adalah:
a. Memperjelas tujuan yang ingin dicapai
b. Membangkitkan minat siswa dengan cara: menghubungkan bahan pelajaran yang akan diajarkan dengan kebutuhan siswa, menyesuaikan materi pelajaran dengan tingkat pengalaman dan kemampuan siswa, serta menggunakan berbagai model dan strategi pembalajaran secara bervariasi
c. Menciptakan suasana yang menyenangkan dalam belajar 
d. Memberi pujian yang wajar terhadap setiap keberhasilan siswa

e. Memberikan penilaian

f. Memberi komentar terhadap hasil pekerjaan siswa

g. Menciptakan persaingan dan kerjasama

7. Guru sebagai evaluator

Sebagai evaluator, guru berperan untuk mengumpulkan data atau informasi tentang keberhasilan pembelajaran yang telah dilakukan. Ada dua fungsi peran guru sebagai evaluator, yaitu:

a. Untuk menentukan keberhasilan siswa dalam mencapai tujuan yang telah ditentukan atau menentukan keberhasilan siswa dalam menyerap materi kurikulum

b. Untuk menentukan keberhasilan guru dalam melaksanakan seluruh kegiatan yang telah diprogramkan.

Menurut Moon (Hamzah B. Uno, 2010: 22) terdapat beberapa peran guru dalam pembelajaran tatap muka, yaitu:

1. Guru sebagai perancang pembelajaran (designer of instruction)

Sebagai perancang pembelajaran, guru harus memperhatikan berbagai komponen dalam sistem pembelajaran yang meliputi:

a. Membuat dan merumuskan TIK

b. Menyiapkan materi yang relevan dengan tujuan, waktu, fasilitas, perkembangan ilmu, kebutuhan dan kemampuan siswa

c. Merancang metode yang disesuaikan dengan situasi dan kondisi siswa

d. Menyediakan sumber belajar

e. Menyediakan media pembelajaran

2. Guru sebagai pengelola pembelajaran (manager of instruction)

Sebagai manager, guru harus mampu mempergunakan pengetahuan tentang teori belajar mengajar dan teori perkembangan hingga memungkinkan untuk menciptakan situasi belajar yang baik mengendalikan pelaksanaan pengajaran dan pencapaian tujuan

3. Guru sebagai pengarah pembelajaran

Sebagai pengarah pembelajaran hendaknya guru senantiasa menimbulkan, memelihara, dan meningkatkan motivasi peserta 
didik untuk belajar. Ada empat hal yang dapat dikerjakan guru dalam memberikan motivasi, yaitu:

a. Membangkitkan dorongan siswa untuk belajar

b. Menjelaskan secara konkrit apa yang dapat dilakukan pada akhir pengajaran

c. Memberikan penghargaan terhadap prestasi yang dicapai hingga merangsang pencapaian prestasi yang lebih baik di kemudian hari

d. Membentuk kebiasaan belajar yang baik

4. Guru sebagai evaluator (evaluator of student learning)

Tujuan utama penilaian adalah untuk melihat tingkat keberhasilan, efektivitas, dan efesiensi dalam proses pembelajaran, serta untuk mengetahui kedudukan peserta didik dalam kelas atau kelompoknya. Sebagai evaluator, guru hendaknya secara terus menerus mengikuti hasil belajar yang telah dicapai peserta didik dari waktu ke waktu. Informasi yang diperoleh melalui evaluasi ini akan menjadi umpan balik terhadap proses pembelajaran dan dapat dijadikan sebagai titik tolak untuk memperbaiki dan meningkatkan pembelajaran selanjutnya.

5. Guru sebagai konselor

Sebagai konselor diharapkan guru dapat merespons segala masalah tingkah laku yang terjadi dalam proses pembelajaran, sehingga guru dituntut untuk dapat:

a. Menolong peserta didik memecahkan masalah-masalah yang timbul antara peserta didik dengan orang tuanya

b. Memperoleh keahlian dalam membina hubungan yang manusiawi dan dapat mempersiapkan untuk berkomunikasi dan bekerjasama dengan bermacam-macam manusia

6. Guru sebagai pelaksana kurikulum

Keberhasilan dari suatu kurikulum yang ingin dicapai sangat bergantung pada faktor kemampuan yang dimiliki oleh seorang guru. Seorang guru harus memiliki tanggung jawab untuk mengembangkan kurikulum, selain tugas utamanya sebagai pembina kurikulum. Ini berarti bahwa guru dituntut untuk selalu mencari gagaan baru demi penyempurnaan praktik pendidikan dan praktik pembelajaran pada khususnya. Hal ini harus dilakukan agar hasil belajar peserta didik dapat ditingkatkan dari waktu ke waktu.

Menurut Hamalik (Kunandar, 2010: 58) bahwa paling tidak terdapat 13 peranan guru di dalam kelas, yaitu: 
1. Guru sebagai pengajar menyampaikan ilmu pengetahuan

2. Guru sebagai pemimpin kelas perlu memiliki keterampilan cara memimpin kelompok-kelompok siswa

3. Guru sebagai pembimbing perlu memiliki keterampilan cara mengarahkan dan mendorong kegiatan belajar siswa

4. Guru sebagai pengatur lingkungan perlu memiliki keterampilan mempersiapkan dan menyediakan alat dan bahan pelajaran

5. Guru sebagai partisipan perlu memiliki keterampilan cara memberikan saran, mengarahkan pemikiran kelas, dan memberikan penjelasan

6. Guru sebagai ekspeditur perlu memiliki keterampilan menyelidiki sumber-sumber masyarakat yang akan digunakan

7. Guru sebagai perencana perlu memiliki keterampilan cara memilih, meramu bahan pelajaran secara profesional

8. Guru sebagai supervisor perlu memiliki keterampilan mengawasi kegiatan anak dan keterlibatan kelas

9. Guru sebagai motivator perlu memiliki keterampilan mendorong motivasi belajar siswa

10. Guru sebagai penanya perlu memiliki keterampilan cara bertanya yang merangsang berpikir dan memecahkan masalah

11. Guru sebagai pengajar perlu keterampilan cara memberikan penghargaan kepada siswa yang berprestasi

12. Guru sebagai evaluator perlu memiliki keterampilan cara menilai siswa secara objektif, kontiniu dan komprehensif

13. Guru sebagai konsuler perlu memiliki keterampilan cara membantu siswa yang mengalami kesulitan tertentu.

\section{Kompetensi Guru}

Kompetensi menurut Usman (Kunandar, 2010: 51) adalah suatu hal yang menggambarkan kualifikasi atau kemampuan seseorang, baik yang kualitatif maupun yang kuantitatif. Sedangkan menurut Johnson (Wina Sanjaya, 2006:17) mengemukakan bahwa kompetensi merupakan perilaku rasional guna mencapai tujuan yang dipersyaratkan sesuai dengan kondisi yang diharapkan. Kemudian menurut Roestiyah N.K (Kunandar, 2010: 52) mengartikan kompetensi sebagai suatu tugas memadai atau pemilikan pengetahuan, keterampilan dan kemampuan yang dituntut oleh jabatan tertentu.

Sedangkan Piet dan Ida Sahertian (Kunandar, 2010: 52) mengatakan bahwa kompetensi adalah kemampuan melaksanakan sesuatu yang 
diperoleh melalui pendidikan dan pelatihan yang bersifat kognitif, afektif dan performen.

Dari uraian diatas dapat disimpulkan bahwa yang dimaksud dengan kompetensi guru adalah seperangkat penguasaan kemampuan yang harus ada dalam diri guru yang diperoleh melalui pendidikan dan pelatihan agar dapat mewujudkan kinerjanya secara tepat dan efektif, yang bersifat kognitif, afektif dan performen.

Hamzah B. Uno (2010:18) mengemukakan bahwa ada tiga kompetensi yang harus dimiliki oleh seorang guru, yaitu:

1. Kompetensi pribadi

Beberapa kompetensi pribadi yang semestinya ada pada seorang guru adalah: memiliki pengetahuan yang dalam tentang materi pelajaran yang menjadi tanggung jawabnya dan mempunyai pengetahuan tentang perkembangan peserta didik serta kemampuan untuk memperlakukan mereka secara individual

2. Kompetensi sosial

Kompetensi sosial yang dimiliki seorang guru adalah menyangkut kemampuan berkomunikasi dengan peserta didik dan lingkungan mereka, seperti orang tua, tetangga, dan sesama teman.

3. Kompetensi profesional mengajar

Berdasarkan peran guru sebagai pengelola proses pembelajaran, harus memiliki kemampuan:

a. Merencanakan sistem pembelajaran, seperti: merumuskan tujuan, memilih prioritas materi yang akan diajarkan, memilih dan menggunakan metode, memilih dan menggunakan sumber belajar yang ada, serta memilih dan menggunakan media pembelajaran

b. Melaksanakan sistem pembelajaran, seperti: memilih bentuk kegiatan pembelajaran yang tepat, dan menyajikan urutan pembelajaran secara tepat

c. Mengevaluasi sitem pembelajaran, seperti: memilih dan menyusun jenis evaluasi, melaksanakan kegiatan evaluasi sepanjang proses, dan mengadministrasikan hasil evaluasi

d. Mengembangkan sistem pembelajaran seperti: mengoptimalisasi potensi peserta didik, meningkatkan wawasan kemampuan diri sendiri dan mengembangkan program pembelajaran lebih lanjut.

Menurut Wina Sanjaya (2006:18) seorang guru harus memiliki beberapa kompetensi, diantaranya:

1. Kompetensi pribadi, diantaranya: 
a. Kemampuan yang berhubungan dengan pengalaman ajaran agama sesuai dengan keyakinan agama yang dianutnya

b. Kemampuan untuk menghormati menghargai antar umat beragama

c. Kemampuan untuk berperilaku sesuai dengan norma, aturan dan sistem nilai yang berlaku dalam masyarakat

d. Mengembangkan sifat-sifat terpuji sebagai seorang guru

e. Bersifat demokratis dan terbuka terhadap pembaharuan dan kritik

2. Kompetensi profesional, diantaranya:

a. Kemampuan untuk menguasai landasan kependidikan, misalnya paham akan tujuan pendidikan nasional, tujuan institusional, tujuan kurikuler dan tujuan pembelajaran

b. Pemahaman dalam bidang psikologi pendidikan, misalnya tentang tahapan perkembangan siswa

c. Kemampuan dalam penguasaan materi pelajaran sesuai dengan bidang studi yang diajarkannya

d. Kemampuan dalam mengaplikasikan berbagai metodologi dan strategi pembelajaran

e. Kemampuan merancang dan memanfaatkan berbagai media dan sumber belajar

f. Kemampuan dalam melaksanakan evaluasi pembalajaran

g. Kemampuan dalam menyusun program pembelajaran

h. Kemampuan dalam melaksanakan unsur-unsur penunjang

i. Kemampuan dalam melaksanakan penelitian dan berpikir ilmiah untuk meningkatkan kinerja

3. Kompetensi sosial kemasyarakatan, meliputi:

a. Kemampuan untuk berinteraksi dan berkomunikasi dengan teman sejawat untuk meningkatkan kemampuan professional

b. Kemampuan untuk mengenal dan memahami fungsi-fungsi setiap lembaga kemasyarakatan

c. Kemampuan untuk menjalin kerja sama, baik secara individual maupun secara kelompok.

Dalam Undang-Undang Nomor 14 Tahun 2005 (2006:9) tentang Guru dan Dosen Pasal 10 dikemukakan bahwa kompetensi guru itu mencakup kompetensi pedagogis, kompetensi kepribadian, kompetensi sosial, dan kompetensi profesional. 
Selanjutnya dalam penjelasan pasal 10 ayat (1) dijelaskan sebagai berikut:

a. Yang dimaksud dengan kompetensi pedagogik adalah kemampuan mengelola pembelajaran peserta didik

b. Yang dimaksud dengan kompetensi kepribadian adalah kemampuan yang mantap, berakhlak mulia, arif, dan berwibawa serta menjadi teladan peserta didik

c. Yang dimaksud dengan kompetensi profesional adalah kemampuan penguasaan materi pelajaran secara luas dan mendalam

d. Yang dimaksud dengan kompetensi sosial adalah kemampuan guru untuk berkomunikasi dan berinteraksi secara efektif dan efesien dengan peserta didik, sesama guru, orang tua/wali peserta didik, dan masyarakat sekitar (UU RI No 14 tahun 2005, 2006: 57)

Dari uraian di atas dapat disimpulkan bahwa seorang guru harus mempunyai beberapa kompetensi untuk meningkatkan proses dan hasil belajar, diantara kompetensi tersebut adalah: kompetensi pribadi, kompetensi professional mengajar, dan kompetensi sosial kemasyarakatan yang ketiganya tidak dapat dipisahkan karena sudah menjadi kesatuan yang harus dipunyai seorang Guru. 


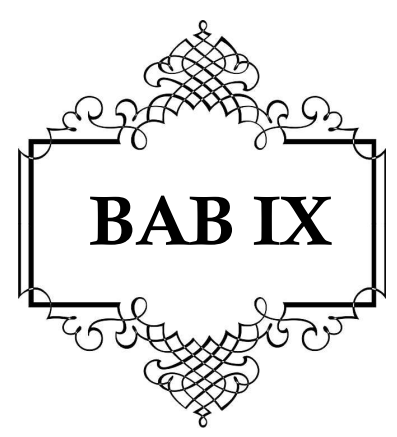

\section{PERENCANAAN PEMBELAJARAN UNTUK ANAK BERKEBUTUHAN KHUSUS}

Setelah membaca bab ini pembaca diharapkan:

+ Memahami konsep dasar perencanaan anak berkebutuhan khusus

* Memahami implementasi perencanaan pembelajaran anak berkebutuhan khusus

\section{A. Konsep Dasar Perencanakan pembelajaran}

Perencanaan (planning) merupakan suatu kegiatan yang penting untuk memperoleh keberhasilan dalam suatu kegiatan. Menurut Made Pidarta (2005:3) perencanaan adalah suatu cara yang memuaskan untuk organisasi tetap berdiri tegak dan maju sebagai satu sistem dalam tenunan suprasistem yang tetap berubah. Sementara Udin Syaefuddin Sa'ud (2005:3)mengartikan perencanaan merupakan suatu rangkaian proses kegiatan menyiapkan keputusan mengenai apa yang diharapkan terjadi (peristiwa, keadaan, suasana, dan sebagainya) dan apa yang akan dilakukan (intensifikasi, eksistensifikasi, revisi, renovasi, substitusi, kreasi, dan sebagainya).

Dalam sudut pandang Koontz sebagaimana dikutip oleh Malayu SP. Hasibuan (2003:92) menerangkan bahwa "perencanaan berhubungan dengan memilih tujuan-tujuan, kebijakan-kebijakan, prosedur-prosedur, program-program dari alternatif yang ada". Jonson (Syafrudin, 2005:63) 
mengartikan perencanaan adalah "suatu rangkaian kegiatan yang sudah ditentukan sebelumnya".

Dengan kata lain perencanaan adalah pekerjaan mental untuk memilih sasaran, kebijakan, prosedur, dan program dengan menggunakan asumsi-asumsi dengan menghubungkan apa yang ada sekarang dengan yang akan datang yang diikuti dengan usaha mencapainya.

Dalam pembelajaran, perencanaan sering diidentikkan dengan perencanaan pembelajaran atau rencana pelaksanan pembelajaran. E. Mulyasa (2006:212) menjelaskan rencana pelaksanan pembelajaran adalah "penjabaran silabus dengan menggambarkan prosedur dan pengorganisasian pembelajaran untuk mencapai kompetensi dasar yang ditetapkan dalam standar isi", yang digunakan "sebagai pedoman guru dalam melaksanakan pembelajaran baik di kelas, laboratorium, di lapangan", dll (Depdiknas, 2006: 38).

a. Hakikat Perencanaan

Rencana Pelaksanaan Pembelajaran pada hakikatnya merupakan perencanaan jangka pendek untuk memperkirakan atau memproyeksikan apa yang akan dilakukan dalam pembelajaran. Dengan memperkirakan tindakan yang akan dilakukan dalam kegiatan pembelajaran. Rencana Pelaksanaan Pembelajaran bermuara pada pelaksanaan pembelajaran yang sekurangnya mencakup tiga kegiatan yaitu identifikasi kebutuhan, perumusan kompentensi dasar, dan penyusunan program pembelajaran (E. Mulyasa, 2006:213).

1) Identifikasi Kebutuhan

Kebutuhan merupakan sesuatu yang harus dipenuhi untuk mencapai tujuan. Tujuannya adalah untuk melibatkan dan memotivasi peserta didik agar kegiatan belajar dirasakan oleh mereka sebagai bagian dari hidupnya dan mereka merasa memiliki

2) Identifikasi Kompetensi

Kompetensi yang jelas akan memberikan arah yang jelas terhadap materi yang harus dipelajari, penetapan metode dan media pembelajaran, serta pemberian petunjuk terhadap penilaian. Setiap kompetensi harus merupakan perpaduan dari pengetahuan, keterampilan, nilai dan sikap yang direfleksikan dalam kebiasaan berfikir dan bertindak.

Pembentukan kompetensi melibatkan Intelegensi Question (IQ), Emosional Intelegensi (EI), Creativity Intelegensi (CI) yang secara keseluruhan harus tertuju pada pembentukan Spiritual 
Intelegensi (SI). Sehingga terdapat hubungan antara tugastugas yang dipelajari peserta didik di sekolah dengan kemampuan yang diperlukan di dunia kerja, dan untuk hidup di masyarakat. Oleh sebab itu peserta didik perlu mengetahui tujuan belajar dan tingkat penguasaan yang akan digunakan sebagai kriteria pencapaian ketuntasan belajar.

3) Penyusunan Program Pembelajaran

Penyusunan Program Pembelajaran memberikan arah kepada suatu program, sehingga program itu menjadi pedoman yang kongkrit dalam pengembangan program selanjutnya. Penyusunan Program Pembelajaran akan bermuara pada Rencana Pelaksanaan Pembelajaran sebagai produk program jangka pendek, yang mencakup program kegiatan belajar dan proses pelaksanaan program (E. Mulyasa, 2006:2014-216).

b. Fungsi Rencana Pelaksanaan Pembelajaran

Rencana Pelaksanaan Pembelajaran merupakan suatu perkiraan guru mengenai seluruh kegiatan yang akan dilakukan baik oleh guru maupun peserta didik terutama dengan kaitannya dengan pembentukan kompetensi.

Fungsi Rencana Pelaksanaan Pembelajaran adalah sebagai fungsi perencanaan dan fungsi pelaksanaan.

1) Fungsi perencanaan

Rencana Pelaksanaan Pembelajaran hendaknya dapat mendorong guru lebih siap melakukan kegiatan pembelajaran dengan perencanaan yang akan datang. Sehingga setiap akan melakukan pembelajaran guru wajib memiliki persiapan baik tertulis maupun tidak tertulis. Tanpa persiapan guru hanya akan merusak mental dan moral siwa serta akan menurunkan wibawa guru secara keseluruhan" (E. Mulyasa, 2006:217). dan perencanan bertujuan untuk "mengarahkan seorang guru dalam pemilihan dan penggunaan strategi dalam pembelajaran" (Muhaimin,1996:107).

2) Fungsi pelaksanaan

Rencana Pelaksanaan Pembelajaran berfungsi untuk mengefektifkan proses pembelajaran sesuai dengan yang diharapkan. Dalam hal ini materi standar yang dikembangkan disesuaikan dengan kebutuhan dan kemampuannya, mengandung nilai fungsional, praktis, serta disesuaikan dengan 
kondisi dan kebutuhan lingkungan, sekolah dan daerah (E. Mulyasa, 2006:218).

\section{B. Implementasi Perencanaan dalam Sekolah Inklusif}

1. Modifikasi Silabus

Modifikasi silabus menyangkut delapan komponen yang termuat di dalamnya, antara lain; a) Standar kompetensi, b) Kompetensi dasar, c) Indikator, d) Materi pembelajaran, e) Kegiatan pembelajaran, f) Penilaian, g) Alokasi waktu, h) Sumber belajar. Namun jika tidak diperlukan untuk dimodifikasi standar Kompetensi, kompetensi dasar dan alokasi waktu tidak perlu dimodifikasi karena bersifat umum. Berikut contoh silabus untuk anak berkebutuhan khusus;

Tabel 9.1 Contoh silabus siswa reguler

Satuan Pendidikan

Mata Pelajaran

Kelas

Standar Kompetensi
: SD/MI

: Pendidikan Agama Islam

: VI (Enam)

: Akhlak/Tarikh 3. Menceritakan kisah nabi

\begin{tabular}{|l|l|l|l|l|c|c|}
\hline $\begin{array}{c}\text { Kompetensi } \\
\text { Dasar }\end{array}$ & $\begin{array}{c}\text { Indikato } \\
\mathbf{r}\end{array}$ & $\begin{array}{c}\text { Materi } \\
\text { Pembelaja } \\
\text { ran }\end{array}$ & $\begin{array}{l}\text { Kegiatan } \\
\text { Belajar }\end{array}$ & $\begin{array}{c}\text { Penilai } \\
\text { an }\end{array}$ & $\begin{array}{c}\text { Aloka } \\
\text { si } \\
\text { Wakt } \\
\mathbf{u}\end{array}$ & $\begin{array}{c}\text { Sumb } \\
\text { er } \\
\text { Belaj } \\
\text { ar }\end{array}$ \\
\hline 1 & 2 & 3 & 4 & 5 & 6 & 7 \\
\hline $\begin{array}{l}\text { 3.2.Mencerita } \\
\text { kan kisah } \\
\text { kelahiran } \\
\text { Nabi } \\
\text { Muhammad }\end{array}$ & $\begin{array}{l}\text { Menjelas } \\
\text { kan } \\
\text { peristiwa } \\
\text { sebelum } \\
\text { nabi lahir }\end{array}$ & $\begin{array}{l}\text { Kisah Nabi } \\
\text { Muhammad }\end{array}$ & $\begin{array}{l}\text { Mencerita } \\
\text { kan } \\
\text { peristiwa } \\
\text { sebelum } \\
\text { Nabi } \\
\text { Muhamma } \\
\text { d lahir }\end{array}$ & $\begin{array}{l}\text { Penilaia } \\
\text { proses } \\
\text { dan } \\
\text { penilaia } \\
\text { n hasil }\end{array}$ & $\begin{array}{l}3 \times 35 \\
\text { Menit }\end{array}$ & $\begin{array}{l}\text { Buku } \\
\text { Teks }\end{array}$ \\
& & & & & & \\
\end{tabular}

Tabel 9.2 Contoh modifikasi silabus bagi anak yang mengalami hambatan kecerdasan

Satuan Pendidikan

Mata Pelajaran

Kelas

Standar Kompetensi
: SD/MI

: Pendidikan Agama Islam

: VI (Enam)

: Akhlak/Tarikh 3. Menceritakan kisah nabi (Umum) 


\begin{tabular}{|c|c|c|c|c|c|c|}
\hline $\begin{array}{c}\text { Kompetensi } \\
\text { Dasar }\end{array}$ & Indikator & $\begin{array}{c}\text { Materi } \\
\text { Pembelaja } \\
\text { ran }\end{array}$ & $\begin{array}{c}\text { Kegiatan } \\
\text { Belajar }\end{array}$ & Penilaian & $\begin{array}{c}\text { Aloka } \\
\text { si } \\
\text { Wakt } \\
\text { u }\end{array}$ & $\begin{array}{c}\text { Sumber } \\
\text { Belajar }\end{array}$ \\
\hline Umum & $\begin{array}{c}\text { Modifikas } \\
\text { i }\end{array}$ & Modifikasi & Modifikasi & Modifikasi & 6 & $\begin{array}{c}\text { Modifika } \\
\text { si }\end{array}$ \\
\hline $\begin{array}{l}\text { 3.2.Mencerita } \\
\text { kan kisah } \\
\text { kelahiran } \\
\text { Nabi } \\
\text { Muhammad } \\
\text { saw }\end{array}$ & $\begin{array}{l}\text { Menjelask } \\
\text { an } \\
\text { peristiwa- } \\
\text { persitiwa } \\
\text { sebelum } \\
\text { nabi lahir }\end{array}$ & $\begin{array}{l}\text { Kondisi } \\
\text { alam } \\
\text { menyambut } \\
\text { kelahiran } \\
\text { nabi } \\
\text { Muhammad } \\
\text { lahir }\end{array}$ & $\begin{array}{l}\text { Mencerita } \\
\text { kan } \\
\text { tentang } \\
\text { gejala alam } \\
\text { ketika nabi } \\
\text { Muhamma } \\
\text { d saw lahir }\end{array}$ & $\begin{array}{l}\text { Ujian } \\
\text { tulisan } \\
\text { dengan } \\
\text { format } \\
\text { menjodoh } \\
\text { kan } \\
\text { disertai } \\
\text { gambar }\end{array}$ & $\begin{array}{l}2 \times 35 \\
\text { Menit }\end{array}$ & $\begin{array}{l}\text { Kartu } \\
\text { Bergamb } \\
\text { ar }\end{array}$ \\
\hline
\end{tabular}

\section{Modifikasi Rencana Pelaksanaan Pembelajaran}

Senada dengan silabus, rencana pelaksanaan pembelajaran merupakan turunan dari silabus yang telah dirumuskan oleh guru. Di dalamnya juga termuat delapan komponen yang juga ada dalam silabus, namun dalam penulisan pada rpp lebih detail sehingga apa yang direncanakan merupakan gambaran yang akan dilaksanakan oleh guru di dalam kelas. Berikut perbandingan rpp siswa reguler dengan siswa berkebutuhan khusus yang mengalami hambatan kecerdasan;

Formulir 9.1 Contoh Rencana Perangkat Pembelajaran siswa regular

\section{RENCANA PELAKSANAAN PEMBELAJARAN (RPP)}

Sekolah

Mata Pelajaran

Kelas / Semester

Alokasi Waktu

Standar Kompetensi

Kompetensi Dasar

Indikator

Tujuan Pembelajaran

Meteri Pembelajaran

kanak sampai kenabian

Metode Pembelajaran
: SD/MI

: Pendidikan Agama Islam

: $\mathrm{IV} / 1$

: 2 Jpl (1 x pertemuan)

: 3. Menceritakan kisah Nabi (Tarikh)

: 3.2. Menceritakan kisah Nabi Muhammad SAW

: $\quad$ - Menjelaskan peristiwa sebelum nabi lahir

: Mampu menceritakan kisah nabi Muhammad SAW masa kanak-kanak sampai kenabian walaupun secara singkat

: - Kisah Nabi Muhammad SAW, masa kanak-

: Ceramah, tanya jawab, pemberian tugas 


$\begin{array}{cl}\text { Kegiatan Pembelajaran } & : \\ \text { Kegiatan Awal } & : \text { - Salam, berdoa, membaca surat-surat pendek } \\ & \text { - Apersepsi; menanyakan materi yang lalu } \\ & \text { - Melakukan Tanya Jawab: } \\ & \text { - Sebutkan nama nabi yang } 25 \ldots \\ \text { Kegiatan Inti } & : \text { - Menjelaskan peristiwa-peristiwa sebelum } \\ & \text { kelahiran Nabi Muhammad SAW } \\ & \text { - Memberikan contoh suri tauladan masa kanak- } \\ & \text { kanak nabi Muhammad SAW } \\ : & \text { - Mengulang cerita singkat kisah nabi masa } \\ & \text { kanak-kanak } \\ \text { Kegiatan Akhir } & \text { - Memberi tugas PR } \\ & \text { - Berdo'a akhir pelajaran, dan salam } \\ : & \text { - Buku Teks PAI Kelas IV SD/MI } \\ & \text { - Buku Cerita Nabi Muhammad saw } \\ \text { Sumber Belajar } & \\ \text { Penilaian } & \text { - Soal Objektif } \\ & \text { - Portofolio } \\ & \text { - PR }\end{array}$

Mengetahui, Guru Agama Islam Kepala Sekolah

NIP.

NIP.

Formulir 9.2 Contoh Modifikasi Rencana Perangkat Pembelajaran siswa yang mengalami hambatan kecerdasan

RENCANA PELAKSANAAN PEMBELAJARAN (RPP)

Sekolah

Mata Pelajaran

Kelas / Semester

$\mathrm{SD} / \mathrm{MI}$

Alokasi Waktu

: Pendidikan Agama Islam

: IV / 1

: $2 \mathrm{Jpl}$ (1 x pertemuan) (Tidak Dimodifikasi) 
Identitas Siswa

Nama : Jenis Kelamin : Umur : ..Jenis hambatan :

Tingkatan hambatan : Tingkat hambatan :

Alamat :

Kemampuan Saat ini :

Standar Kompetensi

Kompetensi Dasar

Indikator (Modifikasi)
: $\quad$ 3. Menceritakan kisah Nabi (Tarikh) (Tidak

\section{Dimodifikasi)}

: 3.2. Menceritakan kisah Nabi Muhammad

\section{SAW (Tidak Dimodifikasi)}

: Menyebutkan nama tempat, hari kelahiran nabi Muhammad SAW

Tujuan Pembelajaran (Modifikasi) : Mampu menceritakan kisah nabi Muhammad SAW lahir secara singkat (Modifikasi)

Materi Pembelajaran (Modifikasi) : Kisah Nabi Muhammad SAW masa kanak-kanak Metode Pembelajaran (Modifikasi): Ceramah, tanya jawab, pemberian tugas, penguatan, dan kartu bergambar

Kegiatan Pembelajaran

Kegiatan Awal (Modifikasi) - Salam, berdoa, membaca surat-surat pendek

- Apersepsi; menanyakan materi yang lalu

- Melakukan Tanya Jawab:

- Nabi yang terakhir Nabi ...

Kegiatan Inti (Modifikasi) $\quad$ : - Menjelaskan hari kelahiran Nabi Muhammad SAW

- Menjelaskan tempat kelahiran Nabi Muhammad SAW

- Memberikan contoh sifat jujur nabi

Kegiatan Akhir (Modifikasi) : - Mengulang cerita singkat kisah nabi masa kanak-kanak

- Memberi tugas PR

- Berdo'a akhir pelajaran, dan salam

Sumber Belajar (Modifikasi) : - Buku Teks PAI Kelas IV SD/MI

- Buku Cerita Nabi Muhammad saw

- Kartu Bergambar 


\section{Penilaian (Modifikasi) : : - Soal menjodohkan \\ - Portofolio \\ - PR}

Mengetahui,

Guru Agama Islam

Kepala Sekolah

NIP.

NIP.

112 


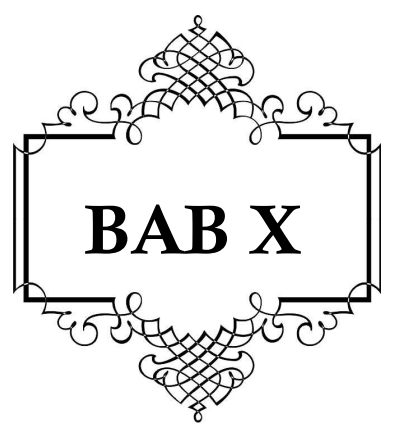

\section{Media Pembelajaran untuk ABK}

Setelah membaca bab ini pembaca diharapkan:

* Memahami konsep dasar media pembelajaran untuk anak berkebutuhan khusus

* Memahami fungsi media pembelajaran untuk anak berkebutuhan khusus

* Memahami jenis-jenis media untuk anak berkebutuhan khusus

* Memahami kriteria pemilihan media untuk anak berkebutuhan khusus

\section{A. Konsep Dasar Media Pembelajaran untuk ABK}

Kata media berasal dari bahasa Latin yaitu Medius, yang secara harfiah berarti 'tengah' atau 'pengantar'. Dalam bahasa Arab, media adalah perantara (وسائل) atau pengantar pesan dari pengirim kepada penerima pesan (Azhar Asyad, 2013:3).

Gerlach dan Ely (Hamdani, 2011:243) mengatakan bahwa media apabila dipahami secara garis besar, media adalah manusia, materi, atau kejadian yang membangun kondisi agar siswa mampu memperoleh pengetahuan, pengetahuan, keterampilan, atau sikap.

Bagi anak berkebutuhan khusus media merupakan sarana untuk memudahkan dalam menerima pelajaran yang diberikan oleh guru sesuai dengan hambatannya. Dengan hambatan yang dialami oleh masing-masing anak berkebutuhan khusus, maka guru hendaknya tidak menerapkan satu 
media untuk semua, akan tetapi mempersiapkan media sesuai dengan jenis hambatan. Untuk itulah media bagi anak berkebutuhan khusus islah

\section{B. Fungsi Media Pembelajaran untuk ABK}

Hamdani (2011:246-248) mengungkapkan beberapa fungsi media dalam pembelajaran, diantarnya;

1. Menyasikan benda yang ada atau peristiwa yang terjadi pada masa lampau. Dengan perantaraan gambar, potret, slide, film, video, atau media yang lain, siswa dapat memperoleh gambaran yang nayata tentang benda atau peristiwa sejarah.

2. Mengamati benda atau peristiwa yang sukar dikunjungi, baik karena jarak jauh, berbahaya, atau terlarang. Misalnya video tentang kehidupan harimau di hutan, keadaan dan kesibukan di pusat reaktor nuklir, dan sebagainya.

3. Memperoleh gambaran yang jelas tentang benda atau hal-hal yang sukar diamati langsung karena ukurannya terlalu besar atau terlalu kecil. Misalnya dengan perantaraan potret, siswa dapat memperoleh gambaran yang jelas tentang bendungan dan kompleks gambaran tentang bakteri, amuba, dan sebagainya.

4. Mendengar suara yang sukar ditangkap dengan telinga secara langsung. Misalnya, rekaman suara denyut jantung dan sebagainya.

5. Mengamati dengan teliti binatang-binatang yang sukar diamati secara langsung karena sukar ditangkap. Dengan bantuan gambar, potret, slide, film atau video, siswa dapat mengamati berbagai macam serangga, burung hantu, kelelawar, dan sebagainya.

6. Mengamati peristiwa-peristiwa yang jarang terjadi atau berbahaya untuk didekati. Dengan slide, film, atau video, siswa dapat mengamati pelangi, gunung meletus, pertempuran, dan sebagainya.

7. Mengamati dengan jelas benda-benda yang mudah rusak atau sukar diawetkan. Dengan menggunakan model atau benda tiruan, siswa dapat memperoleh gambaran yang jelas tentang organ-organ tubuh manusia, seperti jantung, paru-paru, alat pencernaan, dan sebagainya.

8. Dengan mudah membandingkann sesuatu. Dengan bantuan gambar, model atau foto, siswa dapat dengan mudah membandingkan dua benda yang berbeda, seperti sifat, ukuran, warna dan sebagainya.

9. Dapat melihat secara cepat suatu proses yang berlangsung secara lambat. Dengan video, proses perkembangan katak dari telur sampai menjadi katak, dapat diamati hanya dalam waktu beberapa menit. Bunga dari kuncup samapi mekar yang berlangsung beberapa hari, dengan bantuan film dapat diamati hanya dalam beberapa detik. 
10. Dapat melihat secara lambat gerakan-gerakan yang berlangsung secara cepat. Dengan bantuan film, video, siswa dapat mengamati dengan jelas gaya lompat tinggi, teknik loncat indah, yang disajikan secara lambat atau pada saat tertentu dihentikan.

11. Mengamati gerakan-gerakan mesin atau alat yang sukar diamati secara langsung. Dalam film atau video, siswa dapat dengan mudah mengamati jalannya mesin 4 tak, 2 tak, dan sebagainya.

12. Melihat bagian-bagian yang tersembunyi dari suatu alat. Dengan diagram, bagan, model, siswa dapat mengamati bagian mesin yang sukar diamati secara langsung.

13. Melihat ringkasan dari suatu rangkaian pengamatan yang panjang atau lama. Setelah siswa melihat penggilingan tebu di pabrik gula, mereka dapat mengamati secara ringkas proses penggilingan tebu yang disajikan dengan menggunakan film atau video (memantapkan hasil pengamatan).

14. Dapat menjangkau audien yang berjumlah besar jumlahn ya dan mengamati suatu objek secara serempak. Dengan siaran radio atau televisi, ratusan, bahkan ribuan siswa dapat mengikuti kuliah yang disajikan seorang narasumber dalam waktu yang lama.

15. Dapat belajar sesuai dengan kemampuan, kesempatan, dan kecepatan masing-masing.

Dengan adanya media pembelajaran yang di rancang oleh guru, maka hal-hal yang selama ini tidak mereka jumpai mereka temukan di dalam kelas, begitu juga dengan berbagai macam aktifitas yang dapat meraka temukan berkat bantuan dari media tersebut. Untuk guru hendaknya menekankan akan fungsi dari menghadirkan media dalam pembelajarn anak berkebutuhan khusus merupakan sebuah makna dibalik dari media itu sendiri.

\section{Jenis-jenis Media Pembelajaran untuk ABK}

Secara garis besar media pembelajaran terbagi kepada tiga; 1)Visual, 2), Audio, dan 3) Audio-visual. Dalam kegiatan pembelajaran di kelas Hamdani (2011:250-253) memaparkan beberapa jenis media pembelajaran;

\section{Media Grafis}

Media grafis termasuk media visual, sebagaimana halnya media lain, media grafis berfungsi menyalurkan pesan dari sumber ke penerima pesan. Pesan ynag akan disampaikan dituangkan ke dalam simbol-simbol 
komunikasi visual yang bertujuan agar pesan yang disampaikan menjadi efisien. Variasi media grafis ini diantaranya;
a. Gambar dan foto
b. Sketsa
c. Diagram
d. Bagan (Chart)
e. Garafik (graphs)

\section{Teks}

Teks berguna untuk membantu siswa fokus pada materi karena mereka cukup mendengarkan tanpa melakukan aktifitas lain yang menuntut konsentrasi.

\section{Audio}

Media audio memudahkan dalam mengidentifikasi objek-objek, mengklasifikasikan objek, mampu menunjukkan hubungan spasial dari suatu objek, memabantu menjelaskan konsepabstrak menjadi konkret

\section{Grafik}

Media grafik mampu menunjukkan objek dengan ide, menjelaskan konsep yang sulit, menjelaskan konsep yang abstrak menjadi konkret, menunjukkan dengan jelas suatu langkah prosedural

\section{Animasi}

Media animasi mampu menunjukkan suatu proses abastrak sehingga siswa dapat melihat pengaruh perubahan suatu variabel terhadap proses tersebut. Mendia animasi menyediakan suatu tiruan yang apabila dilakukan pada peralatan yang sesungguhnya terlalau mahal atau berbahaya (misalnya; simulasi melihat bentuk tegangan listrik dengan simulasi oscilloscope atau melakukan praktik menerbangkan pesawat dengan simulasi penerbangan.

\section{Video}

Video sangat cocok untuk mengajarkan materi dalam ranah perilaku atau psikomotor. Akan tetapi , video mungkin saja kehilangan detail dalam pemaparan materi karean siswa harus mampu mengingat detail dari scene ke scene. Umumnya, siswa menganggap bahwa belajar melalui video lebih mudah dibandingkan melalui teks sehingga mereka kurang terdorong untuk lebih aktif dalam berinteraksi dengan materi.

Dengan tersedianya berbagai macam jenis media dewasa ini, guru lebih leluasa dalam menentukan media apa yang akan mereka gunakan. 
Kebutuhan akan media dalam kelas inklusif sangat berarti sekali agar tujuan pembelajaran dapat tercapai dengan efektif. Namun dalam penggunaan media hendaknya bagi anak berkebutuhan khusus hendaknya memperhatikan beberapa hal berikut:

a) Pastikan media yang digunakan fleksibel sesuai kondisi ruangan

b) Disarankan menggunakan media yang dapat disimpan jika suatu saat dibutuhkan kembali oleh peserta didik

c) Dalam menggunakan media hendaknya memiliki cadangan jika suatu saat peserta didik mengalami Tantrum (gangguan emosional)

d) Jika ingin menggunakan media elektronik hendaknya dijauhkan dari siswa yang mengalami gangguan perilaku

e) Melakukan evaluasi setelah selesai dalam menggunakan media (menguji keefektifan media)

\section{Kriteria Pemilihan Media Pembelajaran Untuk Anak Berkebutuhan Khusus}

Menurut wina sanjaya (Hamdani, 2011:257) pertimbangan dalam memilih media, antara lain:

1. Acces, artinya kemudahan akses menjadi pertimbangan pertama dalam pemilihan media. Apakah media yang diperlukan itu tersedia, mudah, dan dapat dimanfaatkan? Akses juga menyangkut aspek kebijakan, apakah media tersebut diizinkan untuk digunakan?

2. Cost, artinya pertimbangan biaya. Biaya yang dikeluarkan untuk penggunaan suatu media harus seimbang dengan manfaatnya.

3. Technology, artinya ketersediaan teknologinya dan kemudahan dalam penggunaannya.

4. Interactivity, artinya mampu mengahdirkan komunikasi dua arah atau interaktivitas.

5. Organization, artinya dukungan organisasi atau lembaga dan cara pengorganisasiannya.

6. Novelty, artinya aspek kebaruan dari media yang dipilih. Media yang lebih baru biasanya lebih menarik dan lebih baik.

Hal-hal diatas hendaknya menjadi acuan bagi guru terlebih siswa yang akan dihadapi semakin komplek dalam kelas inklusif. Terlepas dari kriteria di atas hendaknya guru tidak menggunakan media yang bersifat umum hanya untuk seluruh kelas, akan tetapi juga menyediakan media khusus bagi anak-anak yang mengalami hambatan. Namun jika memungkinkan dapat merumuskan sebuah media yang dapat mewadahi 
pada seluruh peserta didik termasuk siswa abk, maka guru hendaknya memperhatikan hal-hal seperti yang telah disebutkan di atas.

Merancang media yang bersifat umum bukan perkara yang mudah, desakan akan habisnya jam pelajaran pada setiap pertemuan menjadi persoalan selanjutnya, maka kebanyakan guru hanaya menediakan satu untuk semua. Sehingga kebutuhan peserta didik berkebutuhan khusus terkadang menjadi nomor dua setelah jam pelajaran hampir berakhir. Menyiasati hal tersebut guru dapat menyusun media satu untuk semua dengan tetap memberikan pesan dalam media yang dibuat ketika proses menjelaskan menjalin komunikasi tanya jawab, atau melibatkan dalam media yang digunakan. Sehingga siswa berkebutuhan khusus terpancing untuk mendengarkan pemaparan materi yang disampaikan oleh guru. 


\section{EVALUASI PEMBELAJARAN ABK}

Setelah membaca bab ini pembaca diharapkan:

* Mengetahui konsep dasar Evaluasi Pembelajaran

\& Menguasai tujuan Evaluasi Pembelajaran

* Mengetahui fungsi Evaluasi Pembelajaran

* Mengetahui prinsip Evaluasi Pembelajaran

* Menguasai jenis Evaluasi Pembelajaran

* Mengetahui Teknik Evaluasi Pembelajaran

* Memahami bentuk laporan akademik anak berkebutuhan khusus

\section{A. Konsep Dasar Evaluasi Pembelajaran}

Secara harfiah evaluasi berasal dari kata "to evaluate" yang berarti menilai. Nilai dalam bahasa Arab disebut "al-Qïmah, al-Taqdi" (Anas Sudjono, 2005:1). Dikenal juga istilah "imtihān yang berarti ujian atau istilah khataman sebagai cara menilai hasil akhir dari proses pendidikan" (M. Arifin, 1991: 274)

Dalam arti luas evaluasi adalah suatu proses merencanakan, memperoleh, dan menyediakan informasi yang sangat perlu untuk membuat alternatif-alternatif keputusan (Ngalim Purwanto, 2002: 3).

Kalau dikaitkan dengan pembelajaran evaluasi adalah "penilaian terhadap tingkat keberhasilan peserta didik mencapai tujuan yang telah ditetapkan dalam pembelajaran" (Muhibbin Syah, 2005:195). "Evaluasi tidak hanya untuk menentukan tingkat keberhasilan belajar, tetapi juga sebagai dasar untuk umpan balik dari proses belajar mengajar yang 
dilakukan" (Muhamad Ali, 2002:113). Oleh sebab itu kemampuan dan keterampilan guru dalam menyusun alat evaluasi dan melaksanakannya merupakan bagian dari kemampuan mengelola kegiatan belajar mengajar secara keseluruhan.

Dalam konsep peyelenggaraan pendidikan inklusif, evaluasi pembelajaran merupakan tolak ukur sejauh mana anak berkebutuhan khusus memahami materi yang diberikan oleh guru sesuai dengan program pengajaranm individual yang telah disusun sebelumnya.

\section{B. Tujuan Evaluasi Pembelajaran}

Evaluasi merupakan proses penyusunan deskripsi peserta didik baik secara kuantitatif maupun kualitatif. Adapun tujuan dari evaluasi menurut Muhibbin Syah (2005:196) adalah:

a) Untuk mengetahui kemajuan yang telah dicapai oleh peserta didik dalam suatu kurun waktu dalam proese belajar tertentu.

b) Untuk mengetahui posisi dan kedudukan seorang peserta didik dalam kelompok kelasnya.

c) Untuk mengetahui tingkat usaha yang dilakukan peserta didik dalam belajar.

d) Untuk mengetahui sejauh mana peserta didik telah mendayagunakan kapasitas kognitifnya untuk belajar.

e) Untuk mengetahui tingkat daya guna dan hasil guna metode mengajar yang telah digunakan guru dalam PBM.

Dengan evaluasi yang baik maka proses pembelajarn anka berkebutuhan khusus akan terlihat sehingga dapat dijadikan bahan perbaikan ataupun penyempurnaan proses pembelajaran selanjutnya. Dalam Undang-undang Sisdiknas Nomor 20 tahun 2003 pasal 58 ayat (1) dijelaskan evaluasi dilakukan untuk memantau proses, kemajuan, dan perbaikan hasil belajar peserta didik secara berkesinambungan (Niki Sae, 2003:136).

\section{Fungsi evaluasi}

Fungsi evaluasi dalam pembelajaran adalah :

a) Fungsi administratif yaitu, untuk penyusunan daftar nilai dan rapor peserta didik

b) Fungsi promosi, yaitu untuk penetapkan kenaikan atau kelulusan

c) Fungsi diagnostik untuk mengidentifikasi kesulitan belajar peserta didik dalam mencapai SKBM dan merencanakan program remedial

d) Sebagai sumber data BP yang dapat memasok data peserta didik tertentu yang memerlukan bimbimngan 
e) Sebagai bahan pertimbangan pengembangan pada masa yang akan datang yang meliputi kurikulum, metode dan alat-alat untuk proses belajar mengajar (Niki Sae, 2003:137).

\section{Prinsip Evaluasi Pembelajaran}

Menurut Abudin Nata (2005:192) dalam evaluasi Pendidikan Agama

Islam terdapat beberapa prinsip yang harus diperhatikan yaitu:

b. Prinsip berkesinambungan (kontinuitas), Seorang guru harus terus menerus mengikuti pertumbuhan, perkembangan, dan perubahah peserta didik. Terus menerus ini bukan hanya sekedar pada kegiatan tes formal tapi juga pada perhatian guru kepada peserta didik ketika duduk, berbicara dan bersikap, baik di kelas saat proses belajar mengajar atau di luar kelas. Dari pengamatan tersebut ada yang perlu dicatat terutama mengenai kelainan pertumbuhan yang diikuti dengan bimbingan.

c. Prinsip menyeluruh, maksudnya penilaian harus mengumpulkan data mengenai seluruh aspek kepribadian, baik yang berhubungan dengan aspek qauliyah, filiyah, atau qalbiyah peserta didik. Dalam istilah Bloom, mengacu kepada tiga ranah, yaitu kognitif, afektif dan psikomotor. Ini dilakukan dengan memperhatikan tingkat perkembangan peserta didik serta bobot tiap aspek dari segenap materi.

d. Prinsip objektif, yaitu melakukan penilaian apa adanya, jujur tanpa melakukan kecurangan sedikit pun.

e. Prinsip sistematis, yakni penilaian dilakukan secara sistematis dan teratur.

Dengan prinsip-prinsip di atas, maka evaluasi yang dilakukan diharapkan mampu meningkatkan kemampuan peserta didik dan kualitas pendidikan secara kelembagaan. Hal itu akan dapat terwujud jika hasil dari evaluasi tersebut ditindak-lanjuti dengan melakukan berbagai pembenahan dan perbaikan kemudian hasil dari pembenahan tersebut terus dievaluasi sehingga memperoleh hasil seperti yang diharapkan.

\section{E. Jenis evaluasi Pembelajaran}

Lalu Muhamad Azwar (1993:118-124) berpendapat bahwa jenis evaluasi dibedakan menjadi 2 macam yaitu evaluasi berdasarkan fungsi dan manfaat dan evaluasi ditinjau dari segi alat evaluasi.

a) Jenis evaluasi berdasarkan fungsi dan manfaat

(1) Tes awal (pree-test), yaitu evaluasi yang dikembangkan sebelum satu satuan pembelajaran disajikan dalam proses belajar mengajar. Fungsinya untuk mengetahui penguasaan peserta didik terhadap materi baru tersebut sebelum diberikan. 
(2) Tes akhir (post-test), yaitu evaluasi yang diberikan setelah selesai satu satuan pelajaran. Fungsinya adalah untuk mengetahui hasil pencapaian tujuan instruksional khusus yang dirumuskan dalam rencana pembelajaran.

(3) Evaluasi formatif / sub sumatif, yaitu evaluasi yang diberikan kepada peserta didik setelah mengikuti / menyelesaikan satuan bahasan tertentu. Fungsinya untuk mengetahui seberapa besar penguasaan peserta didik terhadap satuan bahasan yang dites.

(4) Evaluasi sumatif, yaitu evaluasi yang diberikan kepada sejumlah peserta didik setelah mengukuti atau menyelesaikan beberapa satuan bahasan tertentu. Fungsinya adalah untuk menentukan keberhasilan masing-masing peserta didik dalam mengkuti beberapa program pengajaran dalam waktu tertentu.

(5) Evaluasi belajar tahap akhir, yaitu evaluasi yang diberikan kepada sejumlah peserta didik setelah menyelesaikan seluruh program pengajaran untuk satuan jenjang persekolahan.

(6) Evaluasi diagnostik, yaitu evaluasi yang fungsinya untuk mendiagnosa sebab-sebab kegagalan pengajaran untuk selanjutnya membentu peserta didik memecahkan kegagalan atau kesulitan peserta didik mempelajari bahan pengajaran tersebut.

(7) Evaluasi penempatan, yaitu evaluasi yang menentukan penempatan peserta didik pada suatu program pendidikan yang sesuai dengan tingkat kemampuan, baik dari segi potensi maupun minat dan bakat peserta didik yang bersangkutan.

b) Evaluasi ditinjau dari segi alat evaluasi

(1) Evaluasi menggunakan tes baku (tes standar). Tes ini bisa dijadikan alat ukur secara tepat dan cepat.

(2) Evaluasi menggunakan tes tidak baku, yaitu tes yang tidak diketahui keabsahannya dalam mengukur kemampuan secara tetap dan belum bisa dipercaya ketepatannya

\section{F. Teknik Evaluasi Pembelajaran}

Ada dua teknik yang dapat digunakan dalam melaksanakan evaluasi, yaitu teknik tes dan non tes.

a) Teknik tes

Teknik ini ada yang sudah distandarisasi, artinya tes tersebut sudah mengalami proses ketepatan (validasi) dan reabilitasi untuk suatu tujuan tertentu untuk sekelompok peserta didik. Teknik tes dibedakan menjadi 3 macam yaitu tes lisan, tes tulisan, dan tes perbuatan.

Tes lisan adalah tes yang pelaksanaannya secara lisan, yang bermanfaat untuk hal-hal : 
1. Menilai kemampuan peserta didik dalam memecahkan masalah

2. Menilai proses berfikir peserta didik

3. Menilai kemampuan peserta didik mengkomunikasikan hasil belajar dengan bahasa lisan,

4. Menilai kamampuan peserta didik mempertanggung-jawabkan pendapatnya sehubungan dengan konsep/ ide yang dikemukakan (Lalu Muhamad Azwar, 1993: 124).

Sesuai dengan bentuknya tes lisan bagi anak berkebutuhan khusus dipandu oleh guru mata pelajaran dengan mengarahkan peserta didik untuk mengingat hal-hal yang berhubungan dengan pertanyaan yang diajukan jika pertanyaan tersebut tidak dijawab oleh peserta didik. Seperti; Soal : Dimana Nabi Muhammad dilahirkan?

Arahan Guru : Tempat-tempat yang ada ontanya, atau tempat tempat dimana umat islam mengarahkan kiblatnya, dan lain sebagainya.

Tes perbuatan, adalah tes yang berhubungan dengan kemampuan peserta didik melakukan suatu tindakan atau perbuatan yang berhibungan dengan aspek psikomotor, gunanya untuk mengetahui hal-hal:

1. Mentes kemampuan peserta didik dalam menggunakan alat-alat pelajaran tertentu,

2. Mentes kemampuan peserta didik melakukan suatu perbuatan yang dituntut berdasarkan petunjuk-petunjuk tertentu,

3. Mentes kemampuan peserta didik untuk hal-hal yang sulit dilakukan secara tes tertulis,

4. Memotivasi peserta didik, baik yang mampu maupun yang kurang mampu. Untuk menyadari batas kemampuannya hingga dapat berbuat lebih tekun dan bersungguh-sungguh pada masa berikutnya (Lalu Muhamad Azwar, 1993: 124).

Ketika melakukan gerakan-gerakan yang diperintahkan untuk melakukan secara individual, sebaiknya diberikan terlebih dahulu secara bersama-sama dengan peserta didik reguler lainnya dengan menggunakan metode role play. Sehingga peserta didik yang memiliki hambatan dapat menemukan banyak contoh yang akan diikuti tanpa malu-malu. Selanjutnya diberikan kesempatan untuk melakukan secara individu dengan tetap memberikan pengarahan untuk membetulkan gerakan. Sembari memberikan penilaian.

Tes tulisan, adalah tes yang dilakukan secara tertulis baik pertanyaan maupun jawaban. Tes ini dapat dilakukan untuk kelompok maupun individu. Tes inilah yang populer dikalangan persekolahan karena 
di samping memiliki mamfaat yang cukup luas juga dapat dipersiapkan oleh para guru secara lebih terarah dan terencana.

Menggukan teknik tes tulisan bagi anak berkebutuhan khusus yang mengalami hambatan hampir sama dengan teknik tes lisan, akan tetapi yang menjadi perbedaannya jawaban peserta didik ditulis sendirin atau dibantu oleh guru jika mengalami kesulitan untuk menuliskan jika jawabn lisannya sudah betul. Khusus dalam tes tulisan, dianjurkan peserta didik yang mengalami hambatan secara kecerdasan hendaknya melakukan tes tersebut terpisah dari rekan-rekan sesama siswa (siswa reguler) agar tidak mengganggu pelaksanaan ujian peserta didik lainnya. Tempatnya biasanya di kelas bagian belakang,atau diluar kelas, di perpustakaan, kantor majelis guru atau ruangan khusus lainnya yang tidak mengganggu konsentrasi anak berkebutuhan khusus tersebut.

b) Teknik non tes

Teknik non tes biasanya menggunakan cara-cara berikut:

(2) Wawancara (interview), yaitu tanya jawab tentang materi tertentu yang pelaksanaan secara lisan,

(3) Angket (kuesioner), yakni wawancara tertulis baik pertanyan maupun jawaban dengan mengisi daftar isian,

(4) Pengamatan (observasi), yakni melakukan pengamatan terhadap suatu topik yang pada umumnya diikuti dengan kegiatan diskusi, kerja kelompok, eksperimen, menarrik kesimpulan sementara atau merumuskan hipotesis topik baik secara kelompok maupun individual.

(5) Skala penilaian (rating scale), yaitu penilaian yang lebih banyak berhubungan dengan masalah sikap dengan menggunakan skala penilaian kuantitatif,

(6) Daftar cek (cheklist), yaitu penilaian yang menggunakan daftar cek yang pada umumnya dilakukan berbarengan dengan kegiatan observasi (Lalu Muhamad Azwar, 1993: 125).

Untuk anak berkebutuhan khusus guru hendaknya menentukan kriteria penilaian yang berbeda dengan siswa reguler, sesuai dengan kemampuan peserta didik, media, dan kemampuan guru sendiri dalam menjelaskan pelajaran. Dalam menentukan kriteria penilaian (KKM)

$\square$ Kompleksitas Indikator (Tingkat Kesulitan dan Kerumitan Materi/Bahan Ajar)

Daya Dukung (Ketersediaan Sarana/Prasarana, Kemampuan Guru, Lingkungan dan Biaya)

Intake Siswa (Masukan Kemampuan Siswa) 
Berikut contoh penetuan KKM;

1. Dengan Memberikan point/bobot pada setiap kriteria yang ditetapkan

$$
\begin{aligned}
\square \text { Komplesitas : } & - \text { Tinggi }=1 \\
& - \text { Sedang }=2 \\
& - \text { Rendah }=3 \\
\square \text { Daya Dukung: } & - \text { Tinggi }=3 \\
& - \text { Sedang }=2 \\
& - \text { Rendah }=1 \\
\square \text { Intake Siswa : } & - \text { Tinggi }=3 \\
& - \text { Sedang }=2 \\
& - \text { Rendah }=1
\end{aligned}
$$

Jika suatu indikator memiliki kriteria : Kompleksitas rendah, daya dukung tinggi dan intake siswa sedang maka KKM menjadi :

$$
\left(\frac{3+3+2}{9}\right) \times 100=88.89 \%
$$

2. Dengan menggunakan rentang nilai pada setiap kriteria :

$$
\begin{aligned}
\square \text { Komplesitas : } & - \text { Tinggi }=50-64 \\
& - \text { Sedang }=65-80 \\
& - \text { Rendah }=81-100 \\
\square \text { Daya Dukung: } & - \text { Tinggi }=81-100 \\
& - \text { Sedang }=65-80 \\
& - \text { Rendah }=50-64 \\
\square \text { Intake Siswa : } & - \text { Tinggi }=81-100 \\
& - \text { Sedang }=65-80 \\
& - \text { Rendah }=50-64
\end{aligned}
$$

Jika indikator memiliki kriteria : Komplesitas sedang, daya dukung tinggi dan intake siswa sedang maka KKM adalah rata-rata setiap unsur dari kriteria yang kita tentukan.

\section{G. Bentuk Laporan Akademik Anak Berkebutuhan Khusus}

Sebagaimana siswa reguler setiap pertengahan dan akhir semester selalu menerima hasil studi yang termuat dalam bentuk angka dan huruf serta uraian perkembangan siswa. Guna memberikan gambaran kemampuan peserta didik bagi orang tua masing-masing. Khusus bagi anak berkebutuhan khusus dapat diberikan sebuah laporan akademik dengan bentuk yang disesuaikan dengan kebutuhan masing-masing institusi pendidikan (fleksibel). Hal ini disebabkan laporan akademik yang akan diberikan merupakan juga memuat laporan perkembangan peserta didik. 
Tabel 11.1. Format laporan Akademik Siswa Berkebutuhan Khusus Sekolah

Tahun Pelajaran :

Semester

Nama Siswa

Jenis Hambatan

Tingkat Hambatan :

\begin{tabular}{|l|l|c|c|l|l|}
\hline No & \multirow{2}{*}{ Mata Pelajaran } & \multicolumn{3}{|c|}{ Nilai } & \multirow{2}{*}{ Keterangan } \\
\cline { 3 - 5 } & & KKM & Angka & Huruf & \\
\hline 1 & $\begin{array}{l}\text { Pendidikan Agama } \\
\text { Islam }\end{array}$ & 7.5 & 8 & Delapan & $\begin{array}{l}\text { Masih kurang dalam } \\
\text { memahami materi } \\
\text { yang bersifat abstrak } \\
\text { Komunikasi masih } \\
\text { kurang bagus }\end{array}$ \\
3 & Bahasa Indonesia & 8 & 8.5 & $\begin{array}{l}\text { Delapan } \\
\text { Koma } \\
\text { Lima }\end{array}$ & \\
\hline
\end{tabular}

Saran-saran

1. Agar bunda memberikan pendampingan ektra dirumah tentang diet ketat terhadap makanan yang komposisinya berbahan coklat

2. Sebaiknya ketika dirumah diajak berbicara dengan menggunakan bahasa formal agar membantu komunikasi yang efektif

3. Kalau bisa anak kita dibawa serta shalat berjamaah di masjid sekitar rumah untuk melancarkan praktek pembelajarn pai

4. dst

Mengetahui,

Kepala Sekolah

NIP.

Guru dapat memberikan informasi akademik kepada orang tua sebagai acuan bagi orang tua dalam membantu perkembangan akademik anak berkebutuhan khusus sendiri.
Guru

NIP. 


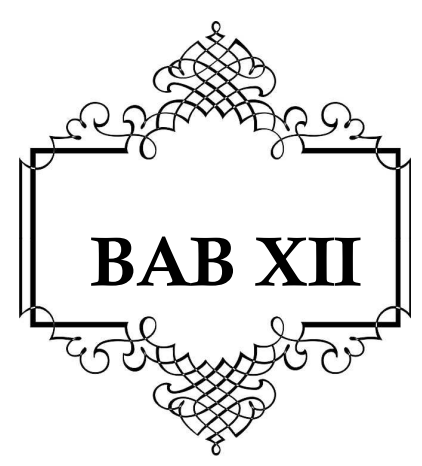

KESIMPULAN

Setelah penulis memaparkan tentang berbagai teori Pendidikan Inklusif, Anak Berkebutuhan Khusus dan panduan praktis dalam mendisain pembelajaran Pendidikan Agama Islam untuk Anak Berkebutuhan Khusus, dapat ditarik beberapa kesimpulan, antara lain;

Pertama, berbagai kritikan dilontarkan oleh pemerhati dikalangan pendidikan islam itu sendiri. Mereka berpendapat bahwa materi yang diajarkan kurang mengena kepada peserta didik sehingga kenakalan remaja belum dapat diatasi dengan baik. Kalau kita koreksi pendapat di atas dari segi proses pembelajaran pendidikan Agama Islam kepada peserta didik, maka kita akan menemukan banyak sekali yang menjadi penghalang internalisasi nilai-nilai agama yang diajarkan guru di sekolah. Mulai dari buku yang digunakan pada sebagian sekolah tidak berdasarkan konten akan tetapi hubungan penerbit dengan pihak sekolah, keteladanan guru yang kurang ikhlas dalam mengajar yang disebabkan berbagai permasalahan di rumah, lingkungan tempat siswa bergaul sehari-hari yang kurang harmonis, keteladanan dari orang tua yang menyuruh tanpa teladan untuk memulai melaksanakan perintah Allah swt hingga tontonan hedonisme yang dapat merobah pola perilaku siswa dalam kehidupan yang penuh pancaroba. Maka dari itu jika diuraikan satu-persatu kita akan menemukan kesalahan pada masing-masing stakeholder yang dapat membantu atau bahkan mempengaruhi proses pendidikan siswa dalam menginternalisasi nilai-nilai agama yang akan diaplikasikan dalam kehidupan sehari-hari.

Kedua, hambatan yang nyata dalam aplikasi pendidikan inklusif di sekolah-sekolah antara lain dikarenakan lambatnya pengambilan 
keputusan dari masing-masing pemerintah daerah baik tingkat I dan II dalam mendeklarasikan provinsi atau kabupaten/ kota penyelenggara pendidikan inklusif, sehingga sekolah-sekolah ragu-ragu dalam menjalankan pendidikan inklusif dengan anggaran yang mesti disahkan oleh pemerintah yang bersangkutan agar kepala sekolah tidak dijatuhi sanksi. Adapun hal lain dikarenakan ketidakpastian tenaga guru pendamping khusus di sekolah-sekolah inklusif berada, sehingga dalam penggajian dan sertifikasi merekapun belum ada aturan yang mewadahi posisi mereka tersebut. Sehingga hal ini berdampak kepada kurangnya minat calon guru pendamping khusus yang untuk mendaftarkan diri ke sekolah-sekiolah inklusif. Tanpa adanya guru pendamping khusus yang tetap maka anak-anak berkebutuhan khusus yang berada di sekolahsekolah hanya dijadikan candaan oleh teman-temannya dan gurupun kurang memberikan perhatian khusus kepada mereka disamping juga dikarenakan kurangnya kesadaran lingkungan sekolah akan makna dari pendidikan inklusif itu sendiri.

Ketiga, kurangnya penghargaan akan keberadaan anak berkebutuhan khusus berkaitan dengan keimanan seseorang akan ciptaan Allah SWT, hal ini dikarenakan mereka mengganggap para penyandang disabilitas ini hanya aib dan kutukan sehingga mereka dipandang sebelah mata, dikucilkan hingga dipasung. Indikator lainnnya lebih disebabkan oleh kurangnya pemahaman masing-masing individu akan kemampuan yang dimiliki dibalik keterbatasan yang mereka alami, berbagai kemampuan mereka miliki baik akademik maupun non akademik. Masyarakat banyak berpendapat bahwa "mengurus diri mereka sendiri saja tidak mampu apalagi menolong orang lain !" hal ini terbantahkan dengan apa yang kita lihat dari tokoh difabel dunia yakni Hellen Keller yang memiliki keterbatasan penglihatan, pendengaran, berbicara. Satu-satunya indra yang dia andalkan untuk berkomunikasi hanyalah indra perasa. Melalui indra perasa ini gurunya berkomunikasi dan memberikan pencerahan hingga dia menjadi tokoh inspirasi yang menggugah dunia dan merobah pandangan dunia akan keberadaan penyandang disabilitas menjadi lebih dihargai.

Keempat, pandangan guru yang universal dalam kelas kelas merupakan sandaran bagi anak berkebutuhan khusus untuk dapat memposisikan diri mereka sebagai seorang siswa seperti siswa yang lainnya. Hal ini memiliki dampak yang sangat luar biasa dalam membangun kepercayaan diri mereka untuk dapat menujukkan eksistensi mereka di lingkungan sekolah yang ramah terhadap kehadiran mereka yang seolaholah tanpa kekurangan suatu apapun juga. Pengakuan akan potensi yang 
mereka miliki secara tidak sengaja menjadi katalisator dalam memacu semangat belajar mereka dan bahkan untuk berkompetisi dengan temanteman sekelasnya. Guru yang tanpa meremehkan kondisi fisik maupun mental siswanya akan mehadirkan suasana kelas yang nyaman dalam membangun silaturrahim yang diridhai Allah swt hingga tercipta pembelajaran yang harmonis.

Kelima, dalam model pendidikan inklusif anak-anak yang mengalami hambatan fisik maupun mental dapat mengikuti pelajaran yang sama dengan anak-anak normal lainnya yang disebut dengan Mainstream (tidak dirubah). Akan tetapi bagi anak yang mengalami hambatan baik fisik maupun mental dan terkendala dalam mengikuti ritme berfikir seperti teman-temannya yang normal, maka modifikasi kurikulum menjadi solusi bagi mereka. Modifikasi kurikulum secara sederhana dapat dilakukan dengan mengurangi indikator pembelajaran, materi pembelajaran, hingga evaluasi proses pembelajaran. Langkah ini mesti diambil oleh guru dan disusun semenjak siswa tersebut di assesmen oleh tenaga referal seperti Psikolog, Guru Pendamping Khusus, dan tenaga yang ekspert dibidangnya. Informasi awal dari hasil assesmen ini sangat menentukan dalam penyusunan rencana pembelajaran yang akan disusun guru dengan GPK dan orang tua ABK yang bersangkutan. Hal ini guna terciptanya hasil yang diinginkan semua pihak.

Keenam, dengan berbagai profesi yang kita geluti tiada hal yang dapat melarang anak berkebutuhan khusus untuk tidak dapat turut serta dalam membangun bangsa ini. Dengan perhatian dan pendidikan yang mereka btuhkan agar mereka dapat menjadi hammab allah yang bertaqwa. Peran orang tua sangat besar dalam mendorong semangat kepada anakanak yang mengalami berbagai hambatan, dengan kepercayaan yang diberikan kepada mereka seolah-oleh telah menghilangkan kekurangan yang mereka alami. Guru sebagai garda terdepan untuk membimbing mereka agar menjadi manusia seutuhnya, perkataan guru dapat melejitkan potensi merak dengan perkataan guru pula mereka menjadi hancur lebur. Untuk itu mari kita rangkul mereka dengan bakat yang dikaruniai Allah swt kepada kita, dengan kelembutan dan kasih sayang niscaya mereka akan mampu melewati masa-masa sulit dalam tumbuh kembang mereka kedepan.

Ketujuh, lingkungan yang positif membawa angin segar bagi mereka yang berkebutuhan khusus, mendahulukan mereka dalam setiap kesempatan, memeberikan peluang usaha, bantuan moril dan modal usaha yang akan memberikan nafkah bagi keluarga mereka. Dengan keterlibatan masyarakat dalam memberikan kepercaan bagi mereka dalam bekerja 
akan membuka jutaan peluang usaha baru yang tanpa disadari lahir dari "tangan-tangan terampil" dengan kreatifitas tinggi. Untuk itulah kami mengajak kita semua untuk membuka satu peluang untuk menjadi sebuah pijakan bagi mereka untuk terjun ditengah masyarakat. 


\section{DAFTAR PUSTAKA}

Ahmad, M, Dkk, Pengembangan Kurikulum, Bandung, Pustaka Setia, 1998, Cet ke-1

Ali, Muhammad, Guru dalam Proses Belajar Mengajar, Bandung, Sinar Baru Algensindo, 2008

Arifin, M, Ilmu Pendidikan Islâm, Jakarta, Bumi Aksara, 1991

Azwandi, Yosfan, Mengenal dan Membantu Penyandang Autisme, Jakarta, DIKTI, 2005

Budiyanto, dkk (Ed), Modul Pelatihan Pendidikan Inklusif, Jakarta, Direktorat PKLK, 2010

B. Uno, Hamzah Profesi Kependidikan, Jakarta, Bumi Aksara, 2010

Blog resmi Kementrian Pendidikan dan Kebudayaan, Https://www.kemdikbud.go.id/main/blog/2017/02/sekolahinklusi-dan-pembangunan-slb-dukung-pendidikan-inklusi Diakses tanggal 15 Agustus 2017

Danuatmaja, Bonny, Terapi Anak Autis di Rumah, Jakarta, Puspa Swara, 2005, Cet ke-3

Daradjat, Zakiah dkk, Ilmu Pendidikan Islam, Jakarta, Bumi Aksara, 1992

Departemen Pendidikan Nasional, Kamus Besar Bahasa Indonesia, Jakarta, Balai Pustaka, 2002, Edisi III, cet ke-2

Buku Saku Kurikulum Tingkat Satuan Pendidikan, Jakarta, Depdiknas, 2006

Pendidikan Adalah Ibadah, Jakarta, DepDikNas, 2004

Direktorat PKLK, Strategi Umum Pembudayaan Pendidikan Inklusif Di Indonesia, Jakarta, Direktorat Pembinaan PKLK, 2013

Pedoman Penyelenggaraan Pendidikan Inklusif sesuai dengan Permendiknas Nomor 70 Tahun 2009, Jakarta, Direktorat PKLK, 2013 
Permendiknas Nomor 70 Tahun 2009, Jakarta, Direktorat PKLK, 2014

Direktoral PSLB, Profil Pendidikan Inklusif Indonesia, Jakarta Kemendiknas, 2010

Griffin, Simone dan Dianne Sandler, Motivate To Communate, Jakarta PT Gramedia Pustaka Utama, 2010

Hakim, Lukmanul, Perencanaan Pembelajaran, Bandung, Cv.Wacana Prima, 2008, Cet ke-2

Hamalik, Oemar Kurikulum dan Pembelajaran, Jakarta, Bumi Aksara, 1999, Cet ke-2

Handojo, Y, Autisme Pada Anak, Jakarta, PT Bhuana Ilmu Populer, 2009

http://tonipurwakarta.blogspot.com/2009/01/azas-azas-kurikulum.html

Idi, Abdullah, Pengembangan Kurikulum Teori dan Praktik, Jakarta, Gaya Media Pratama, 1999

Kresno, Kak, Autism is treatable, Jakarta, PT Elek Media Komputindo, 2011

Kunandar, Guru Profesional, Jakarta, PT RajaGrafindo Persada, 2010

Muhaimin, Strategi Belajar Mengajar, Penerapannya dalam Pembelajaran Pendidikan Agama, Surabaya, Citra Media, 1996

Muhamad Azwar, Lalu, Proses Belajar Mengajar Pola CBSA, Surabaya, Usaha Nasional, 1993

Mulyasa, E, Kurikulum Tingkat Satuan Pendidikan, Bandung, Remaja Rosyda Karya, 2006

Nasution, S, Asas-asas Kurikulum, Jakarta, Bumi Aksara, 1995, Cet ke-2

Nata, Abuddin, Filsafat Pendidikan Islâm, Jakarta, Gaya Media Pratama, 2005

Sejarah Pendidikan Islam, Jakarta, Kencana, 2014, Cet. Ke.2

Nurdin, Syarifuddin, Guru Profesional Dan Implementasi Kurikulum, Jakarta, Quantum Teaching, 2005, Cet ke-3 
Pidarta, Made, Perencanaan Pendidikan Parsipatori, Jakarta, PT. Rineka Cipta, 2005, Cet ke-3

Purwanto, Ngalim, Prinsip-prinsip dan Teknik Evaluasi Pembelajaran, Bandung, PT. Rosyda Karya, 2002

Putra Daulay, Haidar, Dinamika Pendidikan Islam, Bandung, Citapustaka Media, 2004

Rusman, Model-model Pembelajaran, Jakarta, PT Rajagrafindo Persada, 2014, Cet. Ke-5

Sae, Niki, Petunjuk Pelaksanaan Sisdiknas 2003, Jakarta, CV.Ekojaya, 2003

Sudjono, Anas, Pengantar Evaluasi Pendidikan, Jakarta PT Grafindo Persada, 2005

Suyanto dan Mudjito, Masa Depan Pendidikan Inklusif, Jakarta,Kemendikbud Dikdas, 2013

Sumekar, Ganda, Anak Berkebutuhan Khusus, Padang, UNP Press, 2009Muhaimin, Pengembangan Kurikulum Pendidikan Agama Islam, Jakarta, PT. Raja Grafindo Persada, 2005

Sunardi, Kurikulum Pendidikan Luar Biasa dari Masa ke Masa, Jakarta, Puskur Balitbang Kemendiknas, 2010

SP. Hasibuan, Malayu, Manajemen Dasar, Pengertian dan Masalah, Bandung, Sinar Grafika, 2003

Syafrudin, Manajemen Lembaga Pendidikan Islâm, Jakarta, Ciputat Press, 2005

Syah, Muhibbin, Psikologi Belajar, Jakarta, PT. Remaja Rosyda Karya, 2005

Udin Syaefudin, dkk, Perencanaan Pendidikan, Bandung, PT. Remaja RosdaKarya, 2005

Undang-Undang Republik Indonesia Nomor 14 Tahun 2005, Bandung, Citra Umbara, 2006

Yunus, Mahmud Sejarah Pendidikan Islam di Indonesia, Jakarta, Mutiara Sumber Ilmu, 1995, Cet Ke-5 